\title{
Dynamics of Kv10.1 expression through the cell cycle of cancer and non-cancer cells
}

\author{
Dissertation \\ In partial fulfilment of the requirements \\ for the degree "Doktor rerum naturalium" (Dr. rer. nat.) \\ in the Neuroscience Program \\ at the Georg August Universität Göttingen, \\ Faculty of Biology
}

Submitted by

Diana Elizabeth Urrego-Blanco

Born in

Simijaca, Colombia

Göttingen, 2014 


\section{Members of the Thesis Committee:}

Prof. Dr. Luis Angel Pardo, Reviewer

Oncophysiology Group, Max-Planck-Institute of Experimental Medicine

Prof. Dr. Tobias Moser, Reviewer

Dept. of Otorhynolaryngology, Göttingen University Medical School

Prof. Dr. Dr. Detlev Schild

Dept. of Neurophysiology and Cellular Biophysics, Göttingen

University Medical School

Date of the oral examination: $19^{\text {th }}$ of May, 2014 
I hereby declare that this doctoral thesis has been written independently with no other sources and aids than those cited.

Diana Elizabeth Urrego-Blanco

March $31^{\text {st }} 2014$

Göttingen, Germany 
To my parents 


\section{Contents}

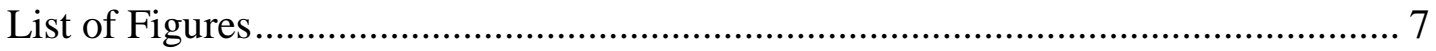

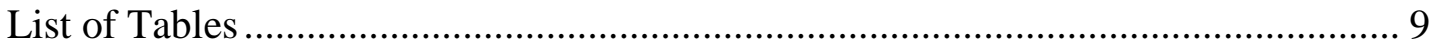

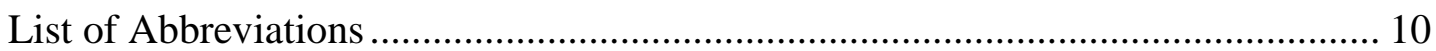

Acknowledgements ........................................................................................ 12

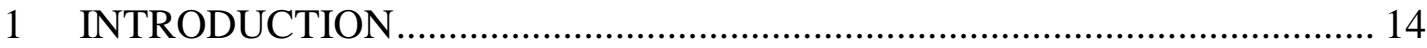

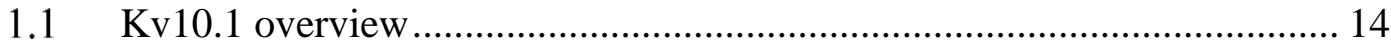

$1.2 \quad \mathrm{Kv} 10.1$ expression and physiological role ................................................ 17

1.2.1 Non tumor tissues .............................................................................. 17

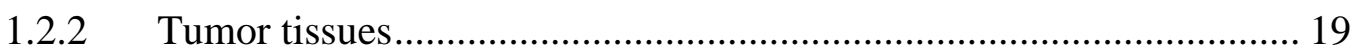

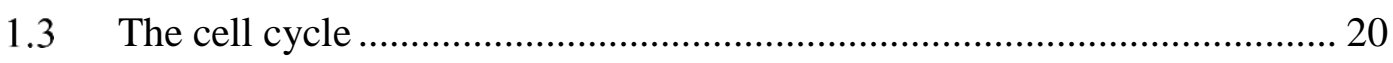

1.3.1 $\mathrm{Rb} / \mathrm{E} 2 \mathrm{~F} 1$ pathway regulation during G1/S transition ............................ 21

1.3.2 Regulation during G2/M transition................................................... 25

1.3.3 Kv10.1 regulation during the cell cycle............................................ 27

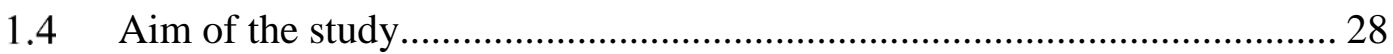

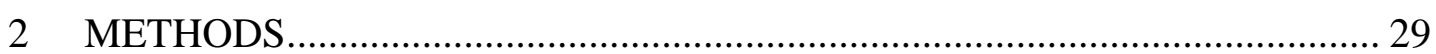

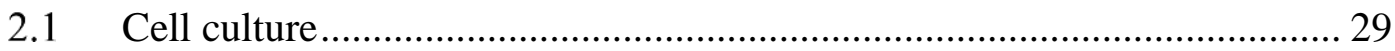

2.1.1 Cell line and drug treatment ............................................................. 29

2.1.2 Cell Synchronization …………………………….......................... 29

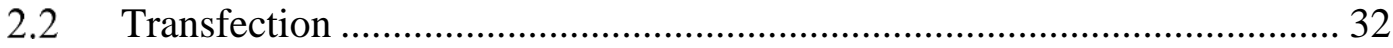

2.2.1 Liposome- mediated Transfection .................................................. 32

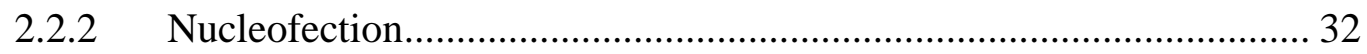

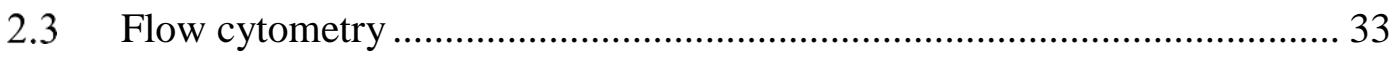

2.4 Site-directed mutagenesis and Transformation............................................ 35

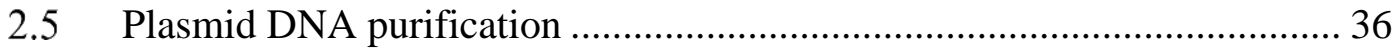

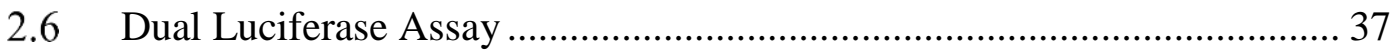

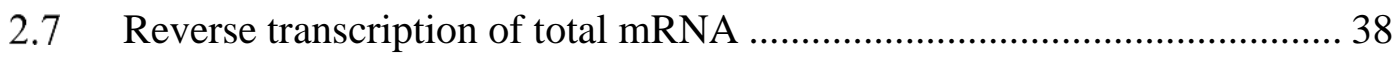

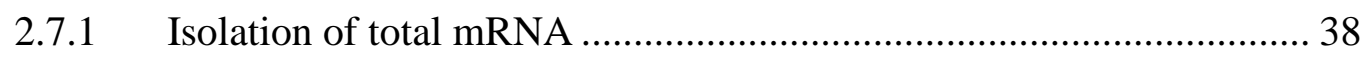

2.7.2 cDNA synthesis from total RNA..................................................... 38

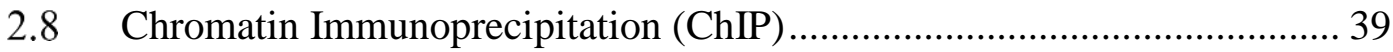

2.9 Quantitative Real Time PCR ………………………………………... 43 
2.9.1 TaqMan assay (fluorescent donor: quencher hybridization) .............. 43

2.9.2 SYBR Green intercalating dye ….................................................. 44

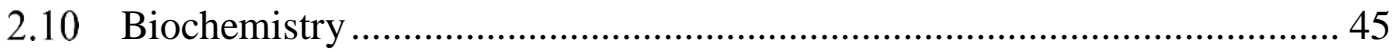

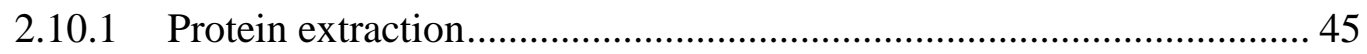

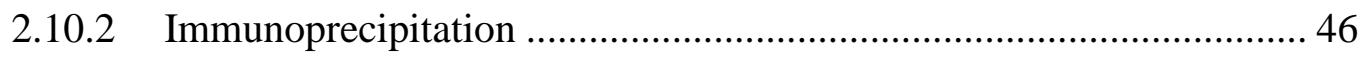

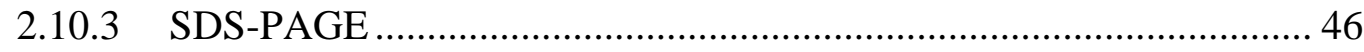

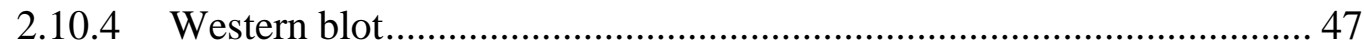

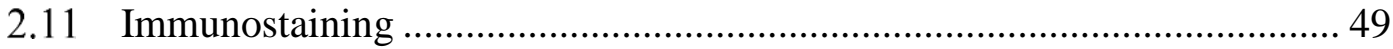

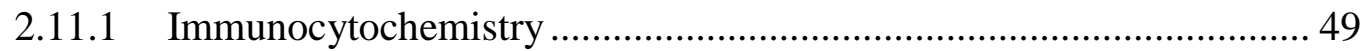

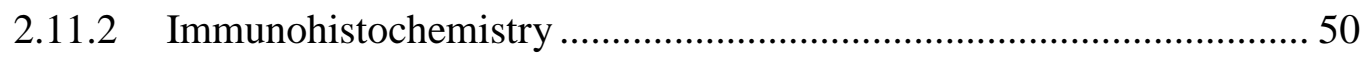

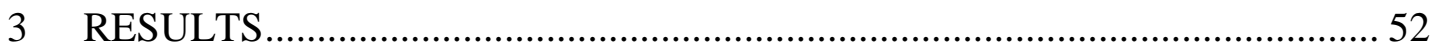

$3.1 \quad$ Kv10.1 expression in HeLa cells .......................................................... 52

3.2 Dynamic expression of Kv10.1 along the cell cycle............................... 56

3.3 Kv10.1 regulation by RB/E2F1pathway.............................................. 61

3.4 Requirement of an E2F1 responsive element for the control of Kv10.1

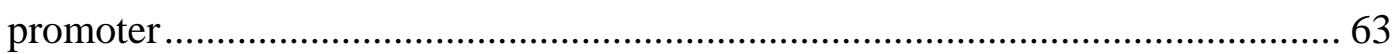

3.5 Interaction of E2F1 with Kv10.1 promoter............................................ 66

3.6 Kv10.1 knockdown delays the G2/M transition of HeLa cells ................... 70

3.7 Kv10.1 expression in normal non-neural tissue....................................... 72

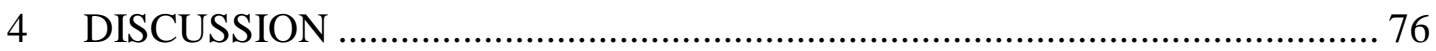

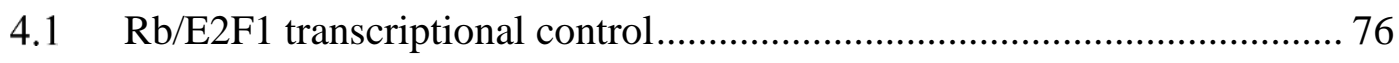

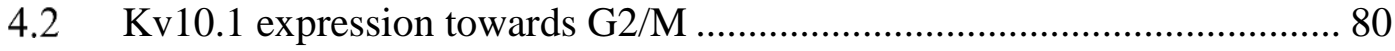

4.3 Rb/E2F1 restricts Kv10.1 expression to the G2/M border ....................... 83

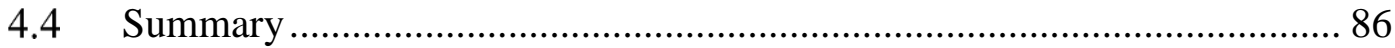

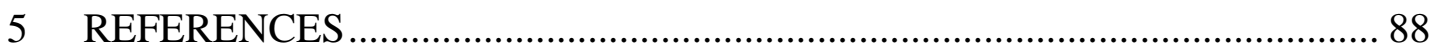

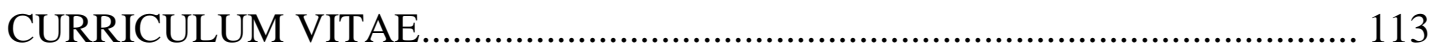

PUBLICATIONS___......... 115 


\section{List of Figures}

Figure 1. Phylogenetic Tree of KCNH family members

Figure 2. Sketch of Kv10.1 subunit.

Figure 3. $\mathrm{Rb} / \mathrm{E} 2 \mathrm{~F} 1$ regulation during G1/S transition.

Figure 4. Degradation of Retinoblastoma protein $(\mathrm{Rb})$ mediated by human papilloma virus (HPV) oncoprotein E7 25

Figure 5. Regulation during G2/M. 26

Figure 6. Double thymidine block protocol

Figure 7. E2F1-Kv10.1 promoter interaction using ChIP assay.....

Figure 8. Subcellular localization of Kv10.1 in HeLa cells 54

Figure 9. Kv10.1 expression and cyclin B1 subcellular localization in HeLa Cells 55

Figure 10. Kv10.1 expression in HeLa Cells has a temporal colocalization with

Cyclin B1 expression

Figure 11. FACS analysis of synchronized HeLa cells using double thymidine block

protocol. 58

Figure 12. Kv10.1 expression pattern along the cell cycle in HeLa cells 60

Figure 13. Kv10.1 expression is regulated by the pRB/E2F1 pathway in HeLa cells

Figure 14. E2F1 responsive element controls KCNH1 activity

Figure 15. E2F1 binding during the cell cycle progression. 68

Figure 16. Analysis of gene expression during the cell cycle in HeLa cells. 69

Figure 17. Kv10.1 knockdown induced G2/M arrest in HeLa cells. 71

Figure 18. Illustration of the crypt axis

Figure 19. Immunohistochemistry of paraffin colon section. 74 
Figure 20. Kv10.1 enriched cells undergo G2/M progression in the proliferative

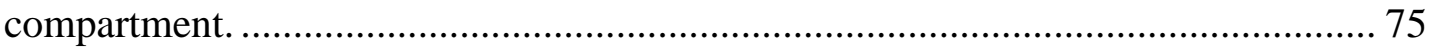




\section{List of Tables}

Table 1. DNA plasmids used for overexpression assays in HeLa cells ................... 33

Table 2. siRNA used for knockdown assays in HeLa cells ..................................... 33

Table 3. Primers used for E2F1 binding site mutagenesis ................................... 35

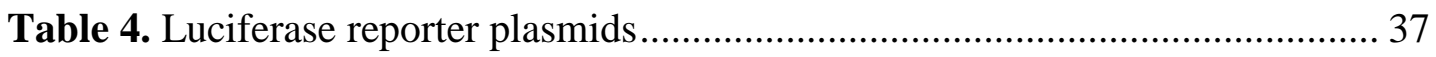

Table 5. TaqMan sets, primers and probes used for qRT-PCR ….......................... 44

Table 6. Primer sets used for ChIP/qRT-PCR ................................................... 45

Table 7. Primary and secondary antibodies used for western blot ......................... 48

Table 8. Primary and secondary antibodies used for Immunocytochemistry ........... 50

Table 9. Primary and secondary antibodies used for Immunohistochemistry .......... 51 


\section{List of Abbreviations}

\begin{tabular}{|c|c|}
\hline ANOVA & Analysis of variance \\
\hline ATM & Ataxia Telangiectasia Mutated protein \\
\hline ATR & Ataxia Telangiectasia Rad-3 \\
\hline BSA & Bovine serum albumin \\
\hline CaMBD & Calmodulin binding domain \\
\hline CCNA2 & Cyclin A2 promoter \\
\hline Cdk & Cyclin-dependent kinases \\
\hline ChIP & Chromatin Immunoprecipitation \\
\hline Chk & Checkpoint Kinase \\
\hline$C M V$ & Cytomegalovirus \\
\hline CNBHD & Cyclic-nucleotide binding homology-domain \\
\hline CNS & Central Nervous System \\
\hline DAPI & 4',6-diamidino-2-phenylindole \\
\hline DMSO & Dimethyl sulfoxide \\
\hline DPBS & Dulbecco's phosphate buffered saline \\
\hline dsDNA & double stranded DNA \\
\hline EDTA & Ethylene diamine tetraacetic acid \\
\hline FCS & Fetal calf serum \\
\hline GAPDH & Glyceraldehyde 3-phosphate dehydrogenase \\
\hline HDAC & Histone deacetylase \\
\hline $\mathrm{HIF}-1 \alpha$ & Hypoxia inducible factor- $1 \alpha$ \\
\hline HNSCC- & Head and neck squamous cell carcinoma \\
\hline HPV & Human papilloma virus \\
\hline HPV-E7 & Human papilloma virus- E7 oncoprotein \\
\hline HRP & Horseradish peroxidase \\
\hline IGF-1 & Insulin-like growth factor 1 \\
\hline $\mathrm{KCNH} 1 \mathrm{pr}$ & Kv10.1 promoter \\
\hline MAPK & Mitogen-activated protein kinase \\
\hline MPF & $\begin{array}{l}\text { Mitosis-promoting factor, a complex of cyclin B and } \\
\text { p34cdc2 }\end{array}$ \\
\hline NLS & Nuclear localization signal \\
\hline PAS & Per-Arnt-Sim domain \\
\hline PBS & Phosphate buffered saline \\
\hline PCR & Polymerase chain reaction \\
\hline PI & Propidium iodide \\
\hline PI3K & Phosphatidylinositol-3 kinase \\
\hline $\mathrm{Rb}$ & Retinoblastoma protein \\
\hline SDS & Sodium dodecyl sulphate \\
\hline TBS & Tris-buffered saline \\
\hline
\end{tabular}


TCC Tetramerization coiled-coil domain

TRAIL TNF-related apoptosis-inducing ligand

VEGF Vascular endothelial growth factor

VHL von Hippel-Lindau, gene product 


\section{Acknowledgements}

Once I heard that we travel not to change place, but to chance our ideas. I moved to Germany to begin a journey, not only through science but also through the world. Now, it is time to express my gratitude to the people who accompanied me in this journey during the last four years.

My deepest gratitude to my supervisor Prof. Dr. Luis Pardo for his guidance and help throughout these years of graduate school. Thanks for keeping your door opened for all our doubts, your passion and commitment to science are an inspiration. I am also indebted to Prof. Dr. Walter Stühmer for his continuous support and encouragement, for all the once-in-a-lifetime experiences, and thanks for your concern for the wellbeing of all students.

I would like to thank the members of my thesis committee Prof. Dr. Tobias Moser and Prof. Dr. Dr. Detlev Schild for their concern about the development of the project. Thanks also to the members of the extended thesis committee Prof. Dr. Matthias Dobbelstein and Dr. Judith Stegmüller for joining in the last, but one of the most crucial steps of the graduate school.

The success of ChIP assays largely rests upon the contributions and expertise from the German Center for Neurodegenerative Diseases (DZNE) led by Prof. Dr. Andre Fischer. Special thanks to the willingness and diligent work of Dr. Magali Hennion, we spent several days dealing with promoter sequences. My sincere thanks to Dr. Alonso Barrantes from the Department of Neuropathology at the Universitätsmedizin Göttingen, for helping us with the tissue collection, and also for all fruitful discussions. I am grateful to the funding and support by the Max Planck Society and the IMPRS Neuroscience. Special thanks to Michael Hörner and Sandra Drube from the IMPRS 
Neuroscience coordination office for their continuous concern and support throughout all these years.

I would also like to thank my co-workers and friends at Max-Planck Institute of Experimental Medicine. I am very grateful to the technical staff from the Department of Molecular Biology of Neuronal Signals for their collaboration during ChIP and FACS experiments, thanks Ushi and Michael! My sincere thanks to Dr. Araceli Sanchez and Dr. Fernanda Gomez, they were always there when they were needed, either to discuss biology, to help with their experience and expertise, or simply to drink a cup of coffee and a big piece of cake. Thanks to all my friends, during this journey I was never on my own. Felipe, Paula, Javier and Juan Martin, Thanks for lending me your ears and showing that not even the ocean can struggle friendship. To my friends in Göttingen, thanks for all the good times!

Adam, thanks for helping me during the long time-course experiments, for all the valuable inputs and revision of this dissertation. Thanks for your amazing patience during my unbearable days, for trusting me and making me believe. Kocham Cie bardzo.

Juan Pablo and Rolando, this would not have been possible without your advices, support, understanding and guidance. I will always be your little sister. My nephews, I wish we all could make a better world for you, I hope I can work on that.

Finally, I want to thank Mom and Dad. Gracias por todas las cosas que nos han enseñado, por señalarnos el norte y hacernos sentir que había un lugar donde caer si algo salía mal. Por confiar y hacernos creer que la perseverancia, el amor y el trabajo honesto al final traen una recompensa. Pero sobre todo, gracias por mostrarnos que para ser felices no hay que ir muy lejos, solo hay que ir a casa. 


\section{INTRODUCTION}

\subsection{Kv10.1 overview}

Kv10.1, also known as Eag1 (Ether-à-go-go-1) is encoded by the KCNH1 gene, and belongs to the $\mathrm{KCNH}$ family of voltage-dependent potassium channels (Gutman, Chandy et al. 2005). KCNH channels form tetramers, and each subunit has six transmembrane segments (S1-S6). The segments S1 to S4 form part of the voltagesensing domain, with S4 carrying most of the voltage-sensing charges, while S5 and S6 contribute to the pore. The KCNH family (Figure 1) has three subfamilies: Kv10 or EAG, Kv11 or ERG (Eag-related-gene), and Kv12 or ELK (Eag-like K+ channels). The common features defining this family are their large intracellular $\mathrm{N}$ - and $\mathrm{C}$ termini, which contain several regulatory domains (Bauer and Schwarz 2001, Gutman, Chandy et al. 2005).

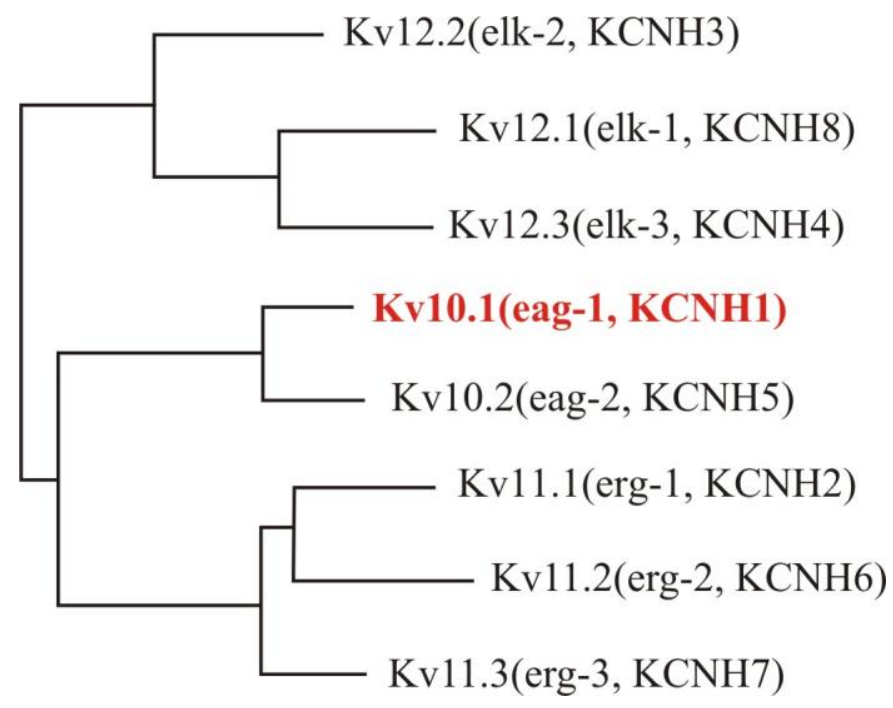

Figure 1. Phylogenetic Tree of KCNH family members. Adapted from Gutman, Chandy et al. 2005 . 


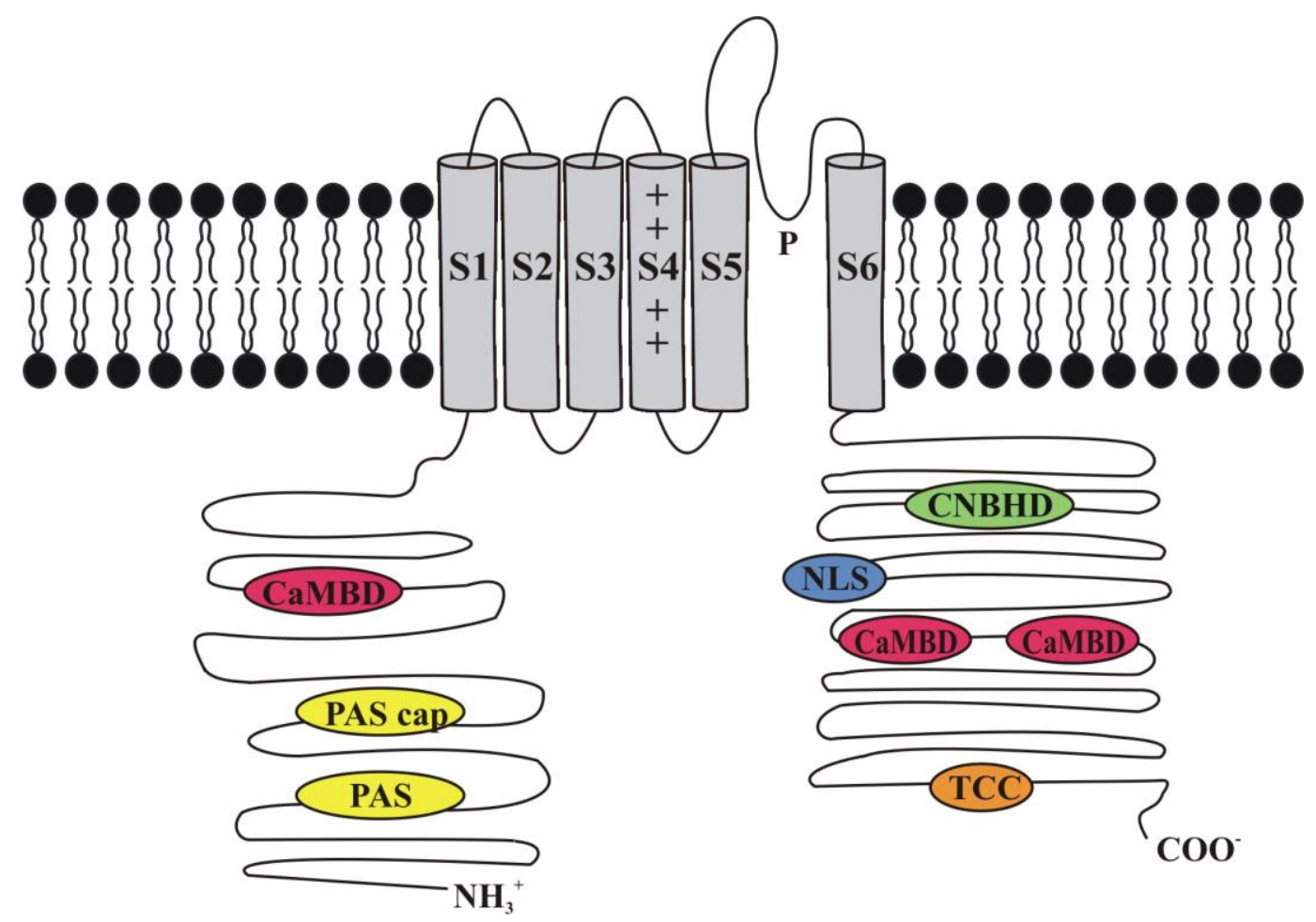

Figure 2. Sketch of Kv10.1 subunit. Transmembrane domains S1-S6. S4 segment is the main voltage sensor, and S5 and S6 form part of the pore. In the N-terminus, the Per-Arnt-Sim domain (PAS/PAC), and one out of three Calmodulin binding domains (CaMBD). In the C-terminus, non-functional cyclic-nucleotide binding homologydomain (CNBHD), a nuclear localization signal (NLS), two CaMBD, and the coiledcoil tetramerization domain (TCC).

As illustrated in Figure 2, the N-terminus of Kv10.1 contains a Per-Arnt-Sim (PAS) domain and a PAC (PAS associated C-terminal) domain (Adaixo, Harley et al. 2013, Haitin, Carlson et al. 2013). PAS domains have been proposed as sensor domains involved in the regulation of cellular responses; the binding of chemically diverse molecules functions as a cue to elicit signaling cascades that regulate responses to environmental change, e.g., hypoxia or light conditions (McIntosh, Hogenesch et al. 2010, Henry and Crosson 2011). The PAS domain in KCNH channels seems to have 
a role in channel gating (Terlau, Heinemann et al. 1997, Morais Cabral, Lee et al. 1998, Li, Gayen et al. 2010). However, the mechanism is not yet fully understood.

On the other hand, the C-terminus of Kv10.1 (Figure 2) contains a cyclic nucleotide binding homology domain (CNBHD), which apparently does not bind cyclic nucleotides except in the Drosophila variant (Bruggemann, Pardo et al. 1993, Marques-Carvalho, Sahoo et al. 2012). However, CNBHD has been shown to interact with the N-terminal PAS domain and seems to regulate gating properties of the channel (Brelidze, Carlson et al. 2012, Marques-Carvalho, Sahoo et al. 2012, Haitin, Carlson et al. 2013). The C-terminus also contains a nuclear localization signal (Chen, Sanchez et al. 2011), and a short domain forming a coiled coil (TCC), which is required for the correct tetrameric assembly and stability of the channel (Jenke, Sanchez et al. 2003). Additionally, it has also been shown that intracellular $\mathrm{Ca}^{2+}$ regulates $\mathrm{Kv10.1}$. The inhibition of the channel is mediated by the $\mathrm{Ca}^{2+}$ binding protein calmodulin (Schonherr, Lober et al. 2000). Thus, three calmodulin binding domains $(\mathrm{CaM})$ have been described, one is located in the N-terminus and the remaining two are located in the C-terminus (Ziechner, Schonherr et al. 2006, Goncalves and Stuhmer 2010).

In heterologous expression systems, Kv10.1 mediates a slowly activating, outward current, which does not inactivate during a sustained depolarization pulse (Ludwig, Terlau et al. 1994, Robertson, Warmke et al. 1996). The rate of activation depends on the holding potential: at more negative prepulse values the time course of activation is slowed down (Bauer and Schwarz 2001). This phenomenon is more pronounced in the presence of extracellular $\mathrm{Mg}^{2+}$ at physiological concentrations (Terlau, Ludwig et al. 1996), and is so distinctive that its occurrence is used as a hallmark to identify endogenous Kv10.1 currents, e.g. (Meyer and Heinemann 1998). 
Due to the homogeneous structural features of the $\mathrm{KCNH}$ family, it has been particularly difficult to obtain specific blockers for Kv10.1 channel. Up to now, application of a selective monoclonal antibody against the extracellular pore region (mAB56) is the only strategy that specifically blocks Kv10.1-mediated currents (Gomez-Varela, Zwick-Wallasch et al. 2007). The tricyclic antidepressant imipramine and the H1 histamine-receptor antagonist astemizole also block Kv10.1 channels. These compounds permeate the lipid bilayer and bind to sites that are only accessible when the channel is open. However, these drugs are nonselective channel blockers, as they can also block the human ether-a-go-go-related channel (hERG). Besides this, Imipramine also blocks chloride channels, and some members of the calciumactivated $\mathrm{K}^{+}$channel family (Carignani and Corsi 2002, Gavrilova-Ruch, Schonherr et al. 2002, Garcia-Ferreiro, Kerschensteiner et al. 2004).

\subsection{Kv10.1 expression and physiological role}

\subsubsection{Non tumor tissues}

\section{Central Nervous System}

Kv10.1 has been reported to be preferentially expressed in the Central Nervous System (CNS). In the brain Kv10.1 is widely distributed (Hemmerlein, Weseloh et al. 2006, Martin, Lino de Oliveira et al. 2008). RT-PCR and immunohistochemistry studies have revealed Kv10.1 expression in the olfactory bulb, cerebral cortex, hippocampus, hypothalamus, and cerebellum (Martin, Lino de Oliveira et al. 2008). Subcellular Kv10.1 localization has been shown mostly at the presynaptic termini in hippocampal neurons (Gomez-Varela, Kohl et al. 2010). However, Kv10.1-deficient mice do not display obvious alterations during embryogenesis and developed normally to 
adulthood; Kv10.1 absence does not lead to any gross anatomical or histological changes in the brain (Ufartes, Schneider et al. 2013). Nevertheless, during repetitive high-frequency stimulation at the parallel fiber - Purkinje cell synapse in Kv10.1deficient mice, facilitation was increased in a frequency- and pulse-dependent manner. This was also accompanied by alteration of the action-potential shape (Mortensen LS 2012). Thus, further studies on Kv10.1 are needed to elucidate its physiological role.

\section{Myoblast differentiation}

Transient expression of Kv10.1 has also been reported to be relevant for myoblast fusion (Bijlenga, Occhiodoro et al. 1998, Occhiodoro, Bernheim et al. 1998). Myoblasts fuse to form multinucleated skeletal muscle fibers, contributing to muscle growth during development. Later, during the postnatal life, myoblast fusion also takes place in muscle repair (Rochlin, Yu et al. 2010). Given the complexity of the musculature, myoblast fusion is a tightly regulated process, where proliferating myoblasts leave the cell cycle, and post-mitotic cells align to finally fuse their membrane (Gorbe, Becker et al. 2006, Hindi, Tajrishi et al. 2013). Different studies have shown that hyperpolarization of the resting potential precedes myoblast fusion, and involves the sequential expression of voltage-gated potassium currents (Bernheim, Liu et al. 1996, Liu, Bijlenga et al. 1998). Expression of Kv10.1-mediated current has been associated with the initial hyperpolarization of the resting potential before myoblast fusion, the current density rises sharply in fusion-competent myoblasts and then declines after fusion. (Bijlenga, Occhiodoro et al. 1998, Occhiodoro, Bernheim et al. 1998). It has been suggested that hyperpolarization increases the $\mathrm{Ca}^{2+}$ driving force, and thus activates $\mathrm{Ca}^{2+}$-dependent pathways, which induce differentiation (Konig, Beguet et al. 2006). 


\subsubsection{Tumor tissues}

A striking feature of Kv10.1 is its widespread presence in tumor biopsies and somatic cancer cell lines, despite being preferentially expressed in brain among normal tissues (Pardo, del Camino et al. 1999, Hemmerlein, Weseloh et al. 2006). Kv10.1 has been detected in over $70 \%$ of human tumor biopsies of diverse origin (Patt, Preussat et al. 2004, Hemmerlein, Weseloh et al. 2006, Mello de Queiroz, Suarez-Kurtz et al. 2006, Ding, Luo et al. 2007, Ding, Yan et al. 2007, Ding, Wang et al. 2008, Agarwal, Griesinger et al. 2010, Asher, Khan et al. 2010, Menendez, Villaronga et al. 2012, del Pliego, Aguirre-Benitez et al. 2013). Its oncogenic potential has been proposed based on the observation that channel blockage or knock-down reduces proliferation of several somatic cancer cell lines (Weber, Mello de Queiroz et al. 2006, Gomez-Varela, Zwick-Wallasch et al. 2007, Downie, Sanchez et al. 2008), and that Kv10.1 overexpression favors xenograft tumor progression in immunodeficient mice in vivo (Pardo, del Camino et al. 1999). Moreover, silencing Kv10.1 expression in glioblastoma cells increases the sensitivity to interferon gamma treatment (Cunha, Del Bel et al. 2013). Thus Kv10.1 also appears as a promising target for cancer therapy. Indeed, approaches taking advantage of its membrane localization and preferential expression in cancer cells have been successfully tested in vitro. Using an anti- Kv10.1 antibody coupled to TRAIL (TNF-related apoptosis-inducing ligand), cancer cells are selectively induced to undergo apoptosis (Hartung, Stuhmer et al. 2011).

The mechanisms of how Kv10.1 favors cell proliferation and enhances tumor progression are poorly understood. Although $\mathrm{K}^{+}$channels influence proliferation through permeation-related mechanisms, providing the driving force required for $\mathrm{Ca}^{2+}$ entry into the cell, and thus releasing $\mathrm{Ca}^{2+}$ signaling cascades implicated in the control of cell proliferation (Lee, Sayeed et al. 1993, Lin, Boltz et al. 1993, Lepple-Wienhues, 
Berweck et al. 1996, Lallet-Daher, Roudbaraki et al. 2009), this does not seem to be the case for Kv10.1. Non-conducting Kv10.1 mutants retain the ability to influence proliferation and tumorigenesis (Hegle, Marble et al. 2006, Downie, Sanchez et al. 2008), indicating that Kv10.1 behaves rather as a bifunctional protein that regulates cell proliferation through permeation-related and non-canonical mechanisms. The latter rely on protein-protein interactions that might activate intracellular signaling pathways. For example, overexpression of the Drosophila Kv10.1 ortholog has been shown to increase cell proliferation in a permeation-independent manner in non-cancer cells. When the non-conducting Kv10.1 mutants were expressed, the increase in cell proliferation was associated with increase of p38 mitogen-activated protein kinase (MAPK) activity. The effect of Kv10.1 on cell proliferation was abolished upon p38 MAPK inhibition (Hegle, Marble et al. 2006). Our group has also reported that Kv10.1 expression favors tumor angiogenesis. The influence on tumor angiogenesis is permeation-independent and associated with the up-regulation of hypoxia inducible factor (HIF-1 $\alpha$ ), and vascular endothelial growth factor (VEGF) (Downie, Sanchez et al. 2008). Nevertheless, these findings are insufficient to explain the influence Kv10.1 has on cell proliferation and tumor progression, as well as its widespread presence in biopsies from various cancers. Thus the relations between Kv10.1 and signaling cascades important for cell cycle progression and intratumoral environment need further clarification.

\subsection{The cell cycle}

In order to maintain homeostasis in normal tissues, eukaryotic cells have developed strategies to carefully control the entry and progression through the cell cycle. Cancer cells, by deregulating these strategies become able to sustain chronic proliferation (Hanahan and Weinberg 2011). The cell cycle starts with the G1 (gap 1) phase, which 
separates the previous cell division from S-phase, when new DNA is synthesized. DNA synthesis is followed by the second gap (G2), and the mitotic phases (M). After mitosis, a cell can reenter the cell cycle in G1 phase, or enter a quiescent state (G0), which can last for a very long time, even for the rest of the life of end-differentiated cells. Progression through the cell cycle is regulated by pathways that depend on one another, meaning that initiation of downstream events is strictly dependent on successful completion of preceding steps. For example, mitosis is dependent on the completion of DNA synthesis. This dependency of events is due to a series of surveillance or control mechanisms termed checkpoints, which have evolved to minimize the production and propagation of genetic mistakes (Hartwell, Culotti et al. 1974, Hartwell and Weinert 1989). The Cyclin/Cyclin-dependent kinases (CyclinCdk) complexes are the key components of cell cycle checkpoints. These complexes are activated by upstream events dependent on the completeness of particular tasks, and trigger responses that contribute to cell cycle progression. Expression of different Cyclins and Cdks changes during cell cycle to ensure sequential progression through its phases (Malumbres and Barbacid 2009). Additionally, kinase activity of CyclinCdk complexes is regulated by Cdk inhibitors, which stop cell cycle progression under unfavorable conditions (Lim and Kaldis 2013). Thus checkpoints are constitutive feedback control pathways, safeguarding the key cell cycle transitions: G1/S, G2/M and the exit from mitosis (Murray 1992, Rieder 2011).

\subsection{1 $\mathrm{Rb} / \mathrm{E} 2 \mathrm{~F} 1$ pathway regulation during $\mathrm{G} 1 / \mathrm{S}$ transition}

Cyclins D and E are the two main classes of cyclins ensuring the progression through G1 phase. Cyclin D interacts with either Cdk4 or Cdk6, and cyclin E forms complexes with Cdk2 (Foster, Yellen et al. 2010). The key substrate of these G1 cyclins is the Retinoblastoma protein $(\mathrm{Rb})$. $\mathrm{Rb}$ binds to the transactivation domain of $\mathrm{E} 2 \mathrm{~F}$ 
transcription factors, and regulates their activity (Rubin, Gall et al. 2005, Burke, Liban et al. 2014). The main mechanism by which $\mathrm{Rb}$ exerts its tumor suppressor function is by repressing E2F activity. The E2F family of transcription factors are DNAbinding proteins essential for transcription of genes involved in cell cycle progression. There are eight different E2Fs, divided into activators (E2F1-E2F3) and repressors (E2F4-E2F8) according to their structure and function (Takahashi, Rayman et al. 2000, Wong, Dong et al. 2011). Rb regulates the transition from G1 to S phase by interactions with the transcription factor E2F1 and histone deacetylase (HDAC). E2F1, in association with its binding partner DP1, activates transcription of target genes needed for $\mathrm{S}$ phase, e.g. cyclin $\mathrm{E}$, cyclin $\mathrm{A}$, whereas HDAC regulates gene expression by modifying the chromatin structure. HDAC removes acetyl groups from histones, and thus the chromatin structure becomes less accessible for transcription (Takaki, Fukasawa et al. 2004).

In the absence of growth signals, $\mathrm{Rb}$ remains in a hypophosphorylated state and represses transcription by recruiting HDAC and repressing E2F1 activity (Figure 3). Upon growth-factor stimulation, cyclin $\mathrm{D}-\mathrm{Cdk} 4 / 6$ complex phosphorylates $\mathrm{Rb}$, inducing conformational changes on $\mathrm{Rb}$ that lead to HDAC release (Suryadinata, Sadowski et al. 2011). Cyclin E gene is transcribed once HDAC is dissociated from $\mathrm{Rb}$. Then cyclin E-Cdk2 complex phosphorylates Rb further. Hyperphosphorylation of $\mathrm{Rb}$ causes the release of E2F1 transcription factor, and the subsequent activation of E2F1 target genes (Wong, Dong et al. 2011). Although the majority of E2F1-induced genes are active during G1/S transition, a number of G2/M regulated genes, including CyclinB1, are also induced by E2F1 (Ishida, Huang et al. 2001, Ren, Cam et al. 2002, Polager and Ginsberg 2003, Zhu, Giangrande et al. 2004). 
The $\mathrm{Rb} / \mathrm{E} 2 \mathrm{~F} 1$ pathway has a critical role in the control of cell proliferation. $\mathrm{Rb}$ is inactivated by DNA viruses such as human papilloma virus (HPV), which is considered a risk factor for head and neck squamous cell carcinomas and cervical cancer (Moody and Laimins 2010, Ramshankar and Krishnamurthy 2013). The proliferation capacity of HPV-infected cells is boosted by HPV oncoproteins E7 and E6, which overcome the negative growth regulation in the host cells. HPV-E7 binds to $\mathrm{Rb}$ and targets it for degradation via the proteasome. HPV-E7 mediated degradation of $\mathrm{Rb}$ requires the calcium activated protease calpain (Darnell, Schroder et al. 2007), which is recruited to $\mathrm{Rb}$ after HPV-E7 binding and induces cleavage of the C-terminus of $\mathrm{Rb}$. As a consequence of cleavage, the proteasomal degradation of $\mathrm{Rb}$ is promoted and E2F1 is released (Figure 4). HPV-E7 binding to Rb can also lead to inhibition of cell growth and apoptosis by activation of p53 and cdk inhibitors (P27 and P21). As a strategy to overcome negative cell growth and apoptotic signals, HPV-E6 targets the tumor suppressor p53 for degradation, and thus facilitates malignant progression (Moody and Laimins 2010). 


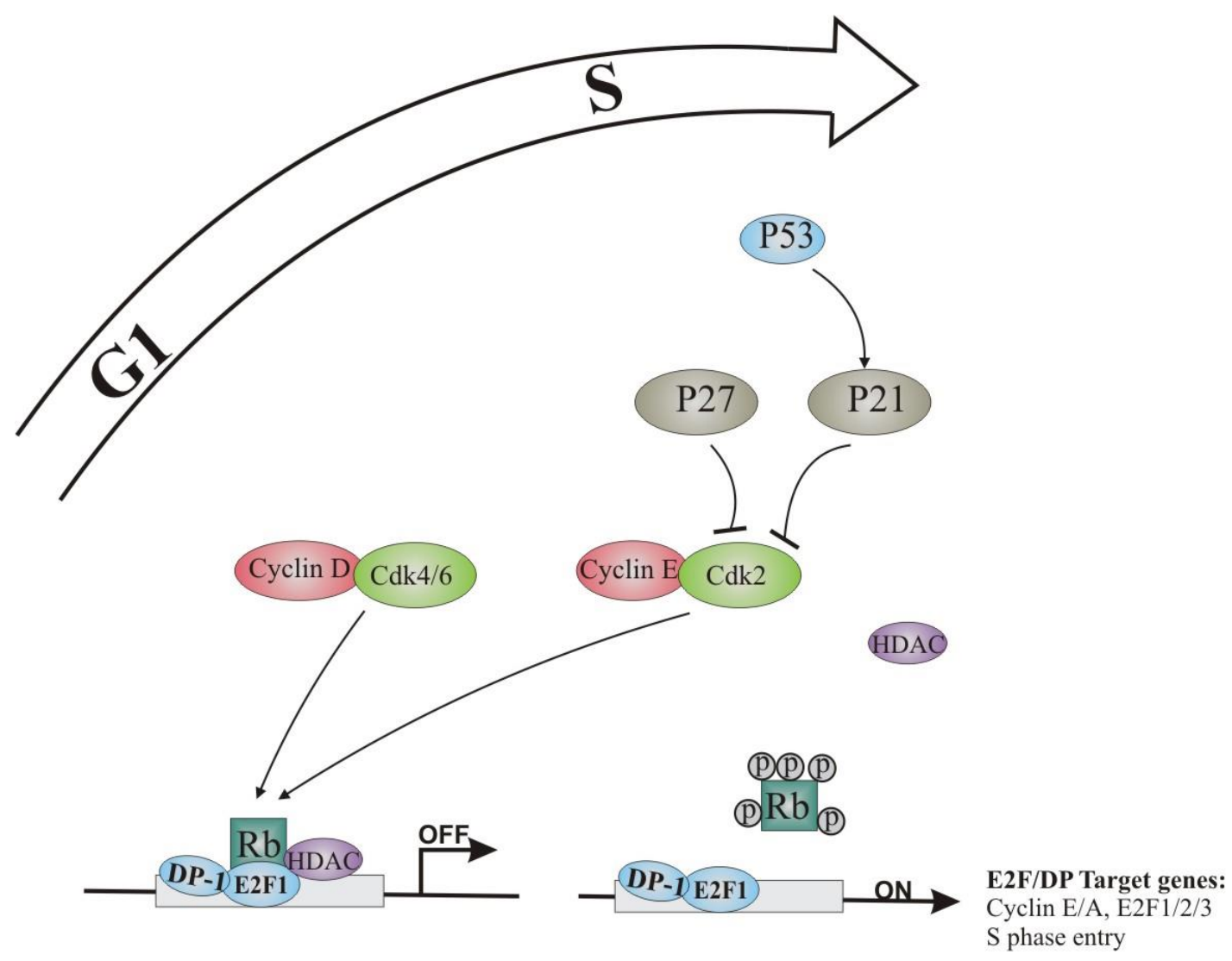

Figure 3. Rb/E2F1 regulation during G1/S transition. Sequential Retinoblastoma protein $(\mathrm{Rb})$ phosphorylation by cyclin D-Cdk4/6 and cyclin E-Cdk2 complexes leads to release of histone deacetylase (HDAC) and E2F1 transcription factor. E2F1 and its binding partner DP1 then activate target genes required for cell cycle progression. Cyclin-Cdk complexes activity is regulated by Cdk inhibitors p27 and p21. 


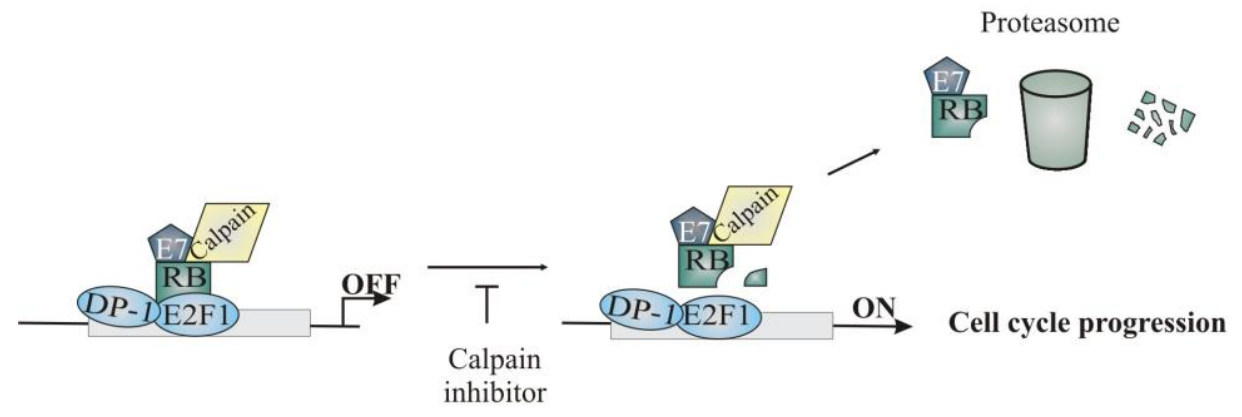

Figure 4. Degradation of Retinoblastoma protein $(\mathrm{Rb})$ mediated by human papilloma virus (HPV) oncoprotein E7. HPV E7 binds to Rb and recruits calpain, a calcium activated protease. Then, calpain induces cleavage at the $\mathrm{C}$ terminus of $\mathrm{Rb}$, and the $\mathrm{Rb}$ is sent for proteasomal degradation. As a result, $\mathrm{E} 2 \mathrm{~F} 1$ is released from $\mathrm{Rb}$ repression, and target genes needed for cell cycle progression are activated.

\subsubsection{Regulation during G2/M transition}

Once the S phase has been finished, the G2 checkpoint (Figure 5) is activated to detect DNA replication mistakes, such as single stranded (ss) - double stranded (ds) DNA junctions. Thus, the $\mathrm{G} 2$ checkpoint prevents mitosis if the genetic information has not been replicated correctly. DNA damage activates either ATM (Ataxia Telangiectasia Mutated protein) or ATR (Ataxia Telangiectasia Rad-3) kinases (Rieder 2011). ATM/ATR phosphorylate Checkpoint kinase 1/2 (Chk), which in turn phosphorylates Cdc25 tyrosine phosphatase. Cdc25 regulates Cdk's activity by removing inhibitory phosphates. Phosphorylation by Chk1/2 leads to Cdc25 inactivation, which prevents entry into mitosis by inhibiting the activity of Cyclin B1-Cdk1 complex (Dai and Grant 2010, Chen, Stephens et al. 2012).

Entry and progression through mitosis depend on the timely regulation of proteins. During G2 phase, Cyclin B1 accumulates exclusively in the cytoplasm around the 
nucleus (Porter and Donoghue 2003). Shortly before nuclear envelope breakdown, the cell is committed to mitosis and cyclin B1 is redistributed into the nucleus. Cyclin B1 interacts with $\mathrm{Cdk} 1$ to orchestrate progression through mitosis. Cdk1 activity is inhibited by Wee1 kinase, whereas Cdc25 phosphatase has the opposite effect, as already mentioned. Cyclin B1-Cdk1 complex regulates the spindle assembly checkpoint to ensure correct chromosomal segregation. During spindle assembly, spindle microtubules attach to kinetochores located on centromeres of replicated chromosomes, so that sister chromatids can be pulled to opposite poles. When the last unattached kinetochore is stably attached to spindle microtubules, the anaphasepromoting complex targets cyclinB1 to induce exit from mitosis (Rieder 2011, Yasutis and Kozminski 2013).

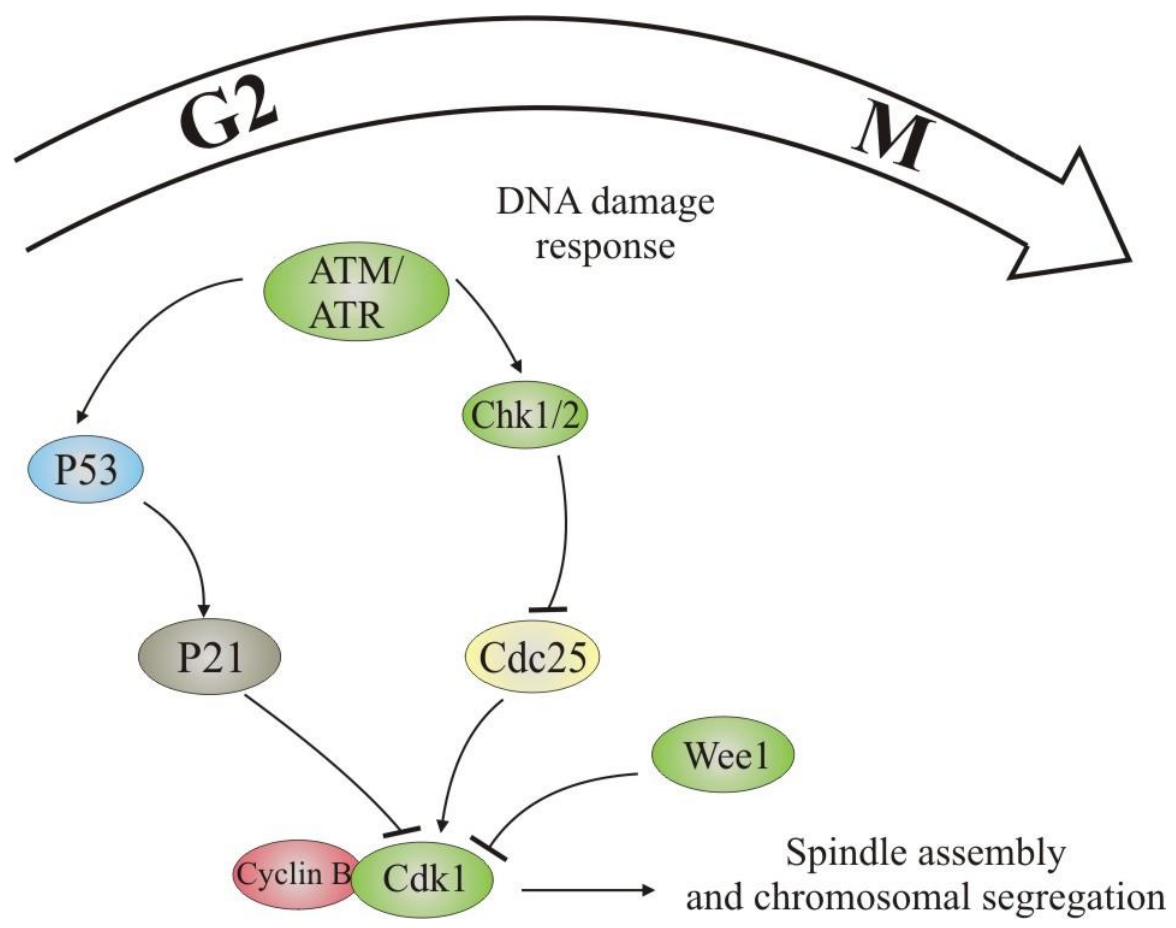

Figure 5. Regulation during G2/M. G2 checkpoint is activated to detect DNA damage before mitotic entry. ATM/ATR phosphorylate Checkpoint kinase (Chk), which phosphorylates the regulatory phosphatase Cdc25. Then, Cdc25 does not activate cyclin B1-cdk1 complex, and entry into mitosis is prevented. 


\subsubsection{Kv10.1 regulation during the cell cycle}

Various studies have reported regulation of ion channels during the cell cycle (Urrego, Tomczak et al. 2014). In the case of Kv10.1, permeability properties of the channels heterologously expressed in Xenopus oocytes are modulated after progesteroneinduced maturation. Progesterone promotes G2/M transition through upregulation of mitosis-promoting factor (MPF, a complex of cyclin $\mathrm{B}$ and $\mathrm{p} 34^{\mathrm{cdc} 2}$ ). Upon MPF activation, Kv10.1-mediated current is strongly reduced (Bruggemann, Stuhmer et al. 1997). This phenomenon is due to a voltage-dependent block by intracellular $\mathrm{Na}^{+}$, and suggests that resulting net loss of $\mathrm{K}^{+}$conductance at $\mathrm{G} 2 / \mathrm{M}$ transition may be a way to favor membrane depolarization associated with mitosis (Pardo, Bruggemann et al. 1998).

Kv10.1 expression has also been reported to be modulated during the cell cycle. In MCF-7 breast cancer cells, G0/G1 synchronization by serum starvation leads to an increase of Kv10.1 mRNA levels compared to the asynchronous control population. Upon serum stimulation, cells progressed through G1 with a further increase of Kv10.1 mRNA. This is also accompanied by an increase in Kv10.1 mediated current density (Ouadid-Ahidouch, Le Bourhis et al. 2001). Indicating that Kv10.1 functional expression is up-regulated as the cells progress through the cell cycle. It has also been shown that insulin-like growth factor 1 (IGF-1) stimulation induces G1 progression in G0/G1 synchronized cells by Cyclin D activation. This effect was reduced upon inhibition or blockage of Kv10.1 (Borowiec, Hague et al. 2007, Borowiec, Hague et al. 2011).

Deregulation of tumor suppressors p53 or Rb can also give rise to higher $\mathrm{Kv} 10.1$ expression levels. Primary keratinocytes overexpressing HPV oncoproteins E6 and E7 
(that respectively target p53 and $\mathrm{Rb}$ ) start to transcribe Kv10.1 mRNA (Diaz et al., 2009). Moreover, there is a positive correlation between HPV infection and Kv10.1 expression in cervical cancer (Farias, Ocana et al. 2004). E2F1-responsive elements have been identified in the Kv10.1 promoter region, while the 3' untranslated region (3'UTR) contains miR34a-regulated sites. In the SH-SY5Y neuroblastoma cell line, free E2F1 upregulates Kv10.1 expression, which is suppressed by miR34a upon p53 activation (Lin et al., 2011).

\subsection{Aim of the study}

Among normal tissues Kv10.1 preferentially localizes in CNS, except for a transient expression in myoblasts before fusion. Kv10.1 has also been recognized for its oncogenic potential in breast, cervical and colon cancer among other malignant tumors. It is thought that the aberrant expression of Kv10.1 channel helps tumor cells acquire selective advantages that allow them to sustain chronic proliferation. Through this study we attempted to elucidate if Kv10.1 expression is timely regulated along the cell cycle, and the molecular mechanisms underlying such expression kinetics. 


\section{METHODS}

\subsection{Cell culture}

\subsubsection{Cell line and drug treatment}

HeLa cells (ACC 57) were obtained from the German Collection of Microorganisms and Cell Lines (DSMZ); and grown in RPMI 1640 (GIBCO/Invitrogen) medium supplemented with $10 \%$ FCS (PAA). Cells were maintained under $5 \% \mathrm{CO}_{2}$ in a humidified atmosphere at $37^{\circ} \mathrm{C}$. For subculture, cells were rinsed with Dulbecco's phosphate buffered saline (DPBS, GIBCO/Invitrogen), detached from the surface of the plate by incubating with Trypsin/EDTA $(0.05 \% / 0.02 \% \mathrm{~W} / \mathrm{V}$, Biochrom $)$ in DPBS for 4 minutes at $37{ }^{\circ} \mathrm{C}$. The enzymatic reaction was stopped by addition of culture medium supplemented with $10 \%$ FCS in a 1:3 volume ratio. Cells were subcultured once they reached 80-90\% confluence at a dilution of 1:10.

Cells were seeded in 6-well plates (200.000 cells/well) 24 hours before treatment. Calpain inhibitor PD150606 (Calbiochem) was dissolved (15 mM) in DMSO (Sigma), and added dropwise to the cells to a final concentration of $150 \mu \mathrm{M}$ during 3 days, as described before by Darnell et al (2007). Cells treated with $0.01 \%$ DMSO and cells without any treatment were taken as control samples. At last the cells were harvested to perform protein extraction and to analyze Kv10.1 level expression by western blot.

\subsubsection{Cell Synchronization}

Cells were synchronized at the $\mathrm{G}_{1} / \mathrm{S}$ border of the cell cycle using a double thymidine block protocol (Figure 6). Excess of thymidine disrupts the balance of deoxyribonucleoside triphosphates (dNTPs) pools, leading to inhibition of DNA synthesis. Thymidine is converted to deoxythymidylate (dTMP), in a reaction 
catalyzed by thymidine kinase (TK). dTMP is then converted to deoxythymidine 5'triphosphate (dTTP), which is one of the four dNTPs needed for DNA synthesis. Ribonucleotide reductase (RNR) catalyzes the reduction of ribonucleotides to the corresponding dNTPs. Binding of dTTP to the allosteric site of the RNR inhibits its activity by regulating the substrate specificity. Thus, inhibition of RNR induces reduction of the dNTP pools. The imbalance in dNTP pools results in inhibition of DNA synthesis and therefore arrest of the cell cycle in G1/S (Reichard 1988).

Cells were seeded in 6-well plates at $40 \%$ confluence and treated for 18 hours with $2 \mathrm{mM}$ thymidine (Sigma) in RPMI culture medium containing $10 \%$ FCS (PAA). Afterwards, cells were washed twice with DPBS and released for 9 hours in the absence of thymidine. Then cells were treated with a second exposure of thymidine for 17 hours. After the double thymidine block, cells were released by washing twice with DPBS and replacing fresh RPMI culture medium with $10 \%$ FCS. Following the first exposure to thymidine, the cells arrested in S phase reenter G1, and those arrested in G1/S progress through G2/M (Figure 6 A). After the second exposure to thymidine, the cells that have entered G1 progress to G1/S transition, and those that have reached G2/M also progress into G1 (Figure 6 B) and become blocked at G1/S owing to the presence of thymidine (Harper 2005). 
A.

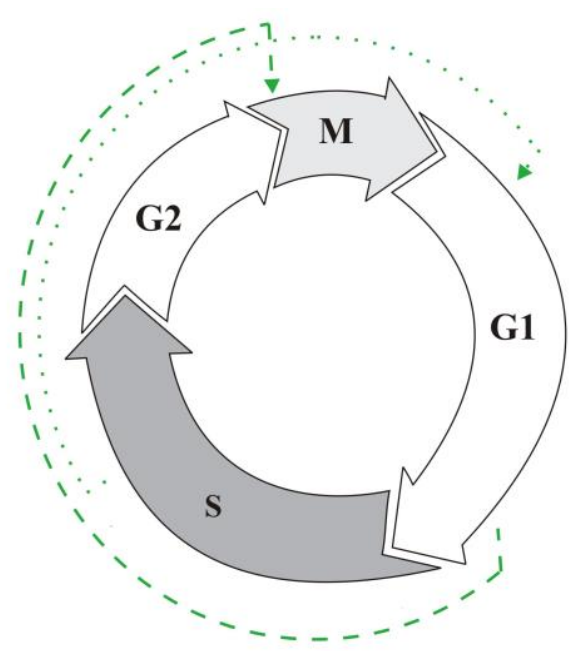

B.

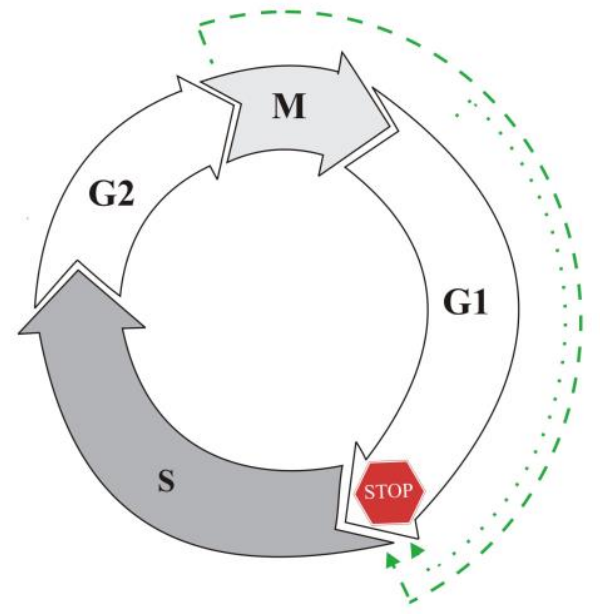

Figure 6. Double thymidine block protocol. Cell division in eukaryotes starts with the G1 (gap 1) phase, which is followed by the period of DNA synthesis (S-phase), then the second gap (G2), and the mitotic (M) phase. (A) During the first exposure to thymidine (18h), the cells are arrested at the G1/S transition and throughout S phase owing to inhibition of DNA synthesis. Following release $(9 \mathrm{~h})$ from the first exposure, cells arrested in G1/S progress through G2 and M phases, while those cells arrested in late $\mathrm{S}$ phase reenter a new cycle and progress to G1 phase. (B) Upon the second exposure to thymidine (17h), cells in $\mathrm{G} 2 / \mathrm{M}$ reenter the next cycle, and progress through G1 phase until they are blocked at the G1/S border. In a similar way, those cells that previously had entered G1 also become arrested in G1/S (Harper 2005). 


\subsection{Transfection}

\subsubsection{Liposome- mediated Transfection}

Transfection was done using Lipofectamine 2000 (Invitrogen). This compound allows the formation of liposomes that interact with the DNA, and enable its uptake by the cells. Cells were seeded in 6-well plates (200.000 cells/well) 24 hours before transfection, the transfection mix per well was prepared according to the manufacturer's instructions, a ratio of $1 \mu \mathrm{g}: 3 \mu \mathrm{L}$ DNA to Lipofectamine 2000 (Invitrogen) was used. The cells were incubated with the transfection mix for 4 hours to allow the uptake of DNA-lipid complex into the cells. Then cells were incubated for 24 hours in supplemented medium before testing for transgene expression.

\subsubsection{Nucleofection}

Using a specific nucleofector solution and applying an electrical pulse, this method is based on the transient permeabilization of the plasma and nuclear membrane, to allow the delivery of plasmid DNA or siRNA into the nucleus. $1 \times 10^{6}$ cells were harvested by trypsinization, centrifuged at $1200 \mathrm{xg}$ for 2 minutes, washed with DPBS, and resuspended in $100 \mu \mathrm{L}$ of Nucleofector Solution R (Lonza). Then, DNA or siRNA was added to the cell suspension. For overexpression experiments, $1 \mu \mathrm{g}$ plasmid DNA was added to the cell suspension (Table 1), knockdown experiments were performed using 30 nM siRNA (Table 2).

The cell/DNA suspension was transferred to the provided cuvette, and inserted into the Nucleofector device (Lonza), which contains determined electrical parameters for each cell line. Thus, the Nucleofector program 0-05 (HeLa cells) was selected in order to apply an electrical pulse to the cell/DNA suspension. Afterwards, $500 \mu \mathrm{L}$ of $10 \%$ FCS supplemented medium was added, and the transfected cell suspension was 
transferred into 6-well plates (final volume $2 \mathrm{~mL}$ medium/well). Gene expression or down regulation was measured after 24 or 48 hours respectively.

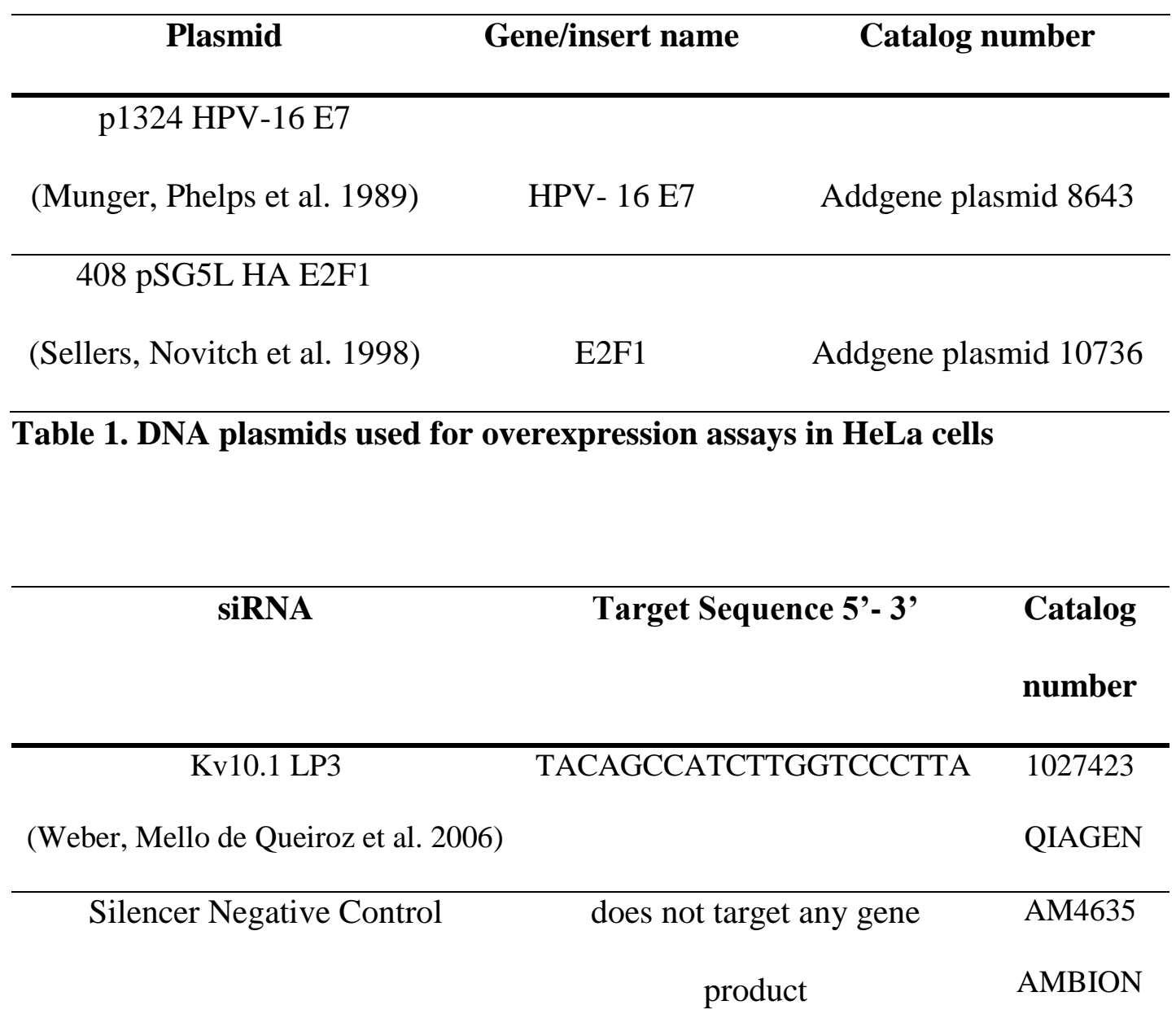

Table 2. siRNA used for knockdown assays in HeLa cells

\subsection{Flow cytometry}

Cell cycle analysis based on DNA content was performed to confirm synchrony and determine the cell cycle distribution after siRNA treatment. Propidium iodide (PI) is a DNA fluorochrome, which binds proportionally to the DNA present in the cell. When the PI stained samples pass through the flow cytometer's laser, the emitted light correlates with the amount of PI bound to the DNA and therefore with the total amount of DNA in the cell. Thus, cells in G0/G1 have a uniform DNA content, whereas cells progressing through $\mathrm{S}$ phase have more DNA, since they are undergoing DNA 
replication, and will take up proportionally more PI. G2/M cells have then twice as much DNA as G0/G1, and therefore, twice as much fluorescence intensity. Cell populations progressing through the different phases of the cell cycle are represented on frequency histograms (Pozarowski and Darzynkiewicz 2004).

PI staining was performed using cycleTEST PLUS DNA Reagent Kit (BD Biosciences) according to manufacturer's instructions. Cells were harvested, washed once with PBS and centrifuged at $1200 \mathrm{x} g$ for 2 minutes. Cell pellets were resuspended and incubated for 10 minutes in $250 \mu \mathrm{L}$ of trypsin buffer, containing spermine to stabilize the chromatin and tetrahydrochloride detergent to remove the cell membrane and cytoskeleton. $200 \mu \mathrm{L}$ of stabilizing buffer containing trypsin inhibitor and ribonuclease A were added and incubated for 10 minutes, to inhibit trypsin activity and to digest RNA. Finally, the isolated nuclei were stained with propidium iodide $(125 \mu \mathrm{g} / \mathrm{mL})$.

The samples were analyzed in a FACS Aria flow cytometer (BD Biosciences). Linear forward and side scatter gates were used to exclude single cells from aggregates and debris. To determine the cell cycle distribution by DNA content analysis, propidium iodide-stained nuclei were analyzed using Argon $488 \mathrm{~nm}$ laser for excitation and the emitted light was collected using a 585/42 nm band pass filter. FACS Diva software v5.0 (BD Biosciences) was used for data acquisition, and data processing was done with FlowJo v10.0.7 software (Tree Star). 


\subsection{Site-directed mutagenesis and Transformation}

Mutations were generated using QuikChange II Site- Directed Mutagenesis Kit (Agilent Technologies) following the manufacturer's instructions. Primers used to create the E2F1 binding site mutation are listed in Table 3.

\begin{tabular}{ccc}
\hline Primer ID. & Sequence 5'- 3' & Manufacturer \\
\hline mutE2F1-Fw & CGCAGGGAGGGAGGATCGTCGAGGGCGCG & Metabion \\
(Lin et al. 2010) & AGGGT & \\
\hline mutE2F1-Rv & ACCCTCGCGCCCTCGACGATCCTCCCTCCC & Metabion \\
(Lin et al. 2010) & TGCG & \\
& & \\
\hline
\end{tabular}

\section{Table 3. Primers used for E2F1 binding site mutagenesis}

PCR sample reaction was set by mixing $10 \mathrm{ng}$ of plasmid DNA template, $125 \mathrm{ng}$ Forward primer (mutE2F1-Fw), $125 \mathrm{ng}$ Reverse primer (mutE2F1-Rv), $1 \mu \mathrm{L}$ of 25 mM dNTP mix, $5 \mu \mathrm{L}$ of 10x Pfu DNA polymerase buffer, $1 \mu \mathrm{L}$ DMSO and $1 \mu \mathrm{L}$ PfuUltra HF DNA polymerase $(2.5 \mathrm{U} / \mu \mathrm{L})$ in $50 \mu \mathrm{L}$ final volume. The PCR sample reaction was then placed into the thermocycler, and the amplification reaction was carried for 18 cycles of $95{ }^{\circ} \mathrm{C}$ for 30 seconds, $55^{\circ} \mathrm{C}$ for 1 minute to allow primer annealing, and 6 minutes extension at $68^{\circ} \mathrm{C}$. In order to digest the methylated parental dsDNA after the site-directed mutagenesis PCR, $1 \mu \mathrm{L}$ of the $D p n I$ restriction enzyme (10 U/ $\mu \mathrm{L}$ ) was added to the PCR amplification product and subsequently incubated during 1 hour at $37{ }^{\circ} \mathrm{C}$. Afterwards $50 \mu \mathrm{L}$ of E. coli DH5 $\alpha$ competent cells were transformed by adding $3 \mu \mathrm{L}$ of the $D p n I$ - treated DNA and incubated on ice for 20 minutes. Cells were then transferred for 1 minute at $42{ }^{\circ} \mathrm{C}$ and placed back on ice for 2 minutes. After addition of $1 \mathrm{~mL} \mathrm{LB}$ medium, cells were incubated for 40 minutes at $37{ }^{\circ} \mathrm{C}$. Subsequently cells were centrifuge at $2300 \mathrm{xg}$ for 2 minutes, $800 \mu \mathrm{L}$ of supernatant was discarded and the cell pellet was resuspended gently into the 
remaining volume. Finally cells were seeded on LB- Agar plates containing ampicilin $[100 \mu \mathrm{g} / \mathrm{mL}]$ or kanamycin [50 $\mu \mathrm{g} / \mathrm{mL}]$ depending on the antibiotic resistance cassette of the plasmid and incubated overnight at $37{ }^{\circ} \mathrm{C}$.

\subsection{Plasmid DNA purification}

In order to purify plasmid DNA, a small scale bacterial culture (mini prep) was set by inoculation of a single colony from transformed E. coli $\mathrm{DH} 5 \alpha$ cells in to $4 \mathrm{~mL} \mathrm{LB}$ medium containing selective antibiotic and incubated overnight at $37{ }^{\circ} \mathrm{C}$ with constant shaking. Afterwards bacterial cells were centrifuged at $2300 \mathrm{xg}$ for 5 minutes at $4{ }^{\circ} \mathrm{C}$ and DNA purification was performed using NucleoSpin ${ }^{\circledR}$ Plasmid Kit (MachereyNagel) following the manufacturer's protocol. Shortly, cell pellet was resuspended and plasmid DNA was released from bacterial cells by SDS/alkaline lysis. Subsequently the lysate was neutralized to favor the plasmid DNA binding to the silica membrane of the NucleoSpin ${ }^{\circledR}$ Plasmid column (Macherey-Nagel). After washing steps to remove contaminants from the silica membrane containing plasmid DNA, this was eluted in $5 \mathrm{Mm}$ Tris/ $\mathrm{HCl}, \mathrm{pH} 8.5$ elution buffer. Plasmid DNA identity was confirmed by restriction analysis and sequencing.

In order to remove endotoxins released from bacterial cells, and thus guarantee a high transfection efficiency and viability of transfected cells, a large scale bacterial culture (100 mL LB medium containing selective antibiotic) from a single colony of transformed $E$. coli $\mathrm{DH} 5 \alpha$ cell was incubated overnight at $37^{\circ} \mathrm{C}$ with constant shaking. DNA purification was performed using NucleoBond Xtra Midi EF Kit (MachereyNagel) following manufacturer's instructions. Then plasmid DNA was sequenced to 
check its integrity and the concentration was determine photometrically by absorbance at 260 and $280 \mathrm{~nm}$ using a nanophotometer UV/VIS (IMPLEN).

\subsection{Dual Luciferase Assay}

HeLa cells were synchronized using the described double thymidine block protocol. Then, cells were released by washing them twice with DPBS (GIBCO/Invitrogen) and replacing fresh culture medium without thymidine. Afterwards, cells were transfected using Lipofectamine 2000 (Invitrogen) in 4 hours intervals with the luciferase reporter plasmids (Table 4). Firefly luciferase- expression was driven by Kv10.1 promoter

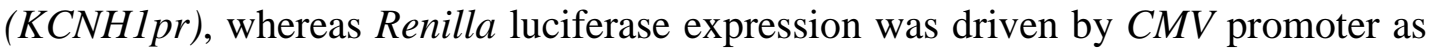
an internal control. Cell pellets were collected for analysis of firefly and Renilla luciferase activity 24 hours after transfection.

\section{Reporter plasmid Promoter}

\begin{tabular}{lll}
\hline pGL3-5'UTR-KCNH1pr (Lin, Li et al. 2011) & KCNH1 promoter (KCNH1pr) \\
\hline pRL-CMV (Promega) & $C M V$ & \\
& & \\
\hline pGL3-5'UTR-mut KCNH1pr & KCNHIpr containing E2F1 & \\
& mutation &
\end{tabular}

\section{Table 4. Luciferase reporter plasmids}

Cell pellets were resuspended in $100 \mu \mathrm{L}$ of Passive Lysis Buffer (Promega), shaked for 15 minutes at room temperature and centrifuged at $16000 \mathrm{xg}$ for 1 minute. Afterwards $20 \mu \mathrm{L}$ of the supernatant was transferred into a 96-well plate to perform dual luciferase assay. First, $100 \mu \mathrm{L}$ of Luciferase Assay Reagent II (Promega) containing firefly luciferase substrate were added to the wells, and firefly luminescence was quantified. Thereafter, firefly luminescence reaction was quenched, 
and simultaneously Renilla luciferase reaction was initiated by adding $100 \mu \mathrm{L}$ of reagent Stop\&Glo ${ }^{\circledR}$ (Promega) containing firefly luciferase substrate. $C M V$ driven Renilla-luciferase activity was used as an internal control for normalization. Data acquisition was done using Perkin Elmer Wallac Victor 2 V Multi-label Counter 1420041 Microplate Reader.

\subsection{Reverse transcription of total mRNA}

\subsubsection{Isolation of total mRNA}

To determine gene expression, total mRNA was isolated from HeLa cells using RNeasy Mini Kit (Qiagen) according to manufacturer's instructions. Cells were harvested and lysed in the presence of guanidine-thiocyanate containing buffer, which inactivates RNases and thus ensures the integrity of the RNA to be purified. In order to shear genomic DNA and reduce viscosity, the lysate was transferred into QIAsheredder spin column (Qiagen) and centrifuged. The homogenized lysate was mixed in a 1:1 proportion with $70 \%$ ethanol, to favor selective binding of RNA to the silica membrane of the column, transferred into the RNeasy mini column (Qiagen), and centrifuged. DNA removal was performed using RNase-free DNase Set (Qiagen), and several washes combined with centrifugation were performed to remove contaminants. Finally the RNA was eluted from the silica membrane by adding RNase free water followed by centrifugation.

\subsection{2 cDNA synthesis from total RNA}

Total mRNA was reverse transcribed using SuperScrip ${ }^{\circledR}$ III First-strand synthesis system (Invitrogen). $2.5 \mu \mathrm{g}$ of total RNA in $12 \mu \mathrm{L}$ of RNase free water were set apart, 
mixed with $1 \mu \mathrm{L}$ of $50 \mu \mathrm{M}$ oligo (dT) $12-18$, and incubated at $70{ }^{\circ} \mathrm{C}$ for 10 minutes to disrupt the RNA secondary structure. The reaction was placed on ice for 1 minute to allow primer annealing, and for the cDNA synthesis reaction, the RNA- primer mix was adjusted to $20 \mu \mathrm{L}$ final volume, containing $1 \mathrm{x}$ RT buffer, $2.5 \mathrm{mM} \mathrm{MgCl} 2,10 \mathrm{mM}$ DTT, $0.5 \mathrm{mM}$ dNTP mix and $10 \mathrm{U} / \mu \mathrm{L}$ SuperScript ${ }^{\circledR I I I}$ RT. The reaction was incubated at $42{ }^{\circ} \mathrm{C}$ for 50 minutes, followed by 15 minutes incubation at $70{ }^{\circ} \mathrm{C}$ to stop it. In order to remove RNA template, $1 \mu \mathrm{L}$ RNase $\mathrm{H}$ was added and incubated at 37 ${ }^{\circ} \mathrm{C}$ for 20 minutes. Finally, cDNA was diluted in water to a final volume of $25 \mu \mathrm{L}$.

\subsection{Chromatin Immunoprecipitation (ChIP)}

ChIP assays were performed to determine the binding of E2F1 transcription factor to Kv10.1 promoter along the cell cycle (Figure 7). HeLa cells were grown on $15 \mathrm{~cm}^{2}$ dishes and synchronized by double thymidine block as described. Starting at the release time, cells (DNA) were cross-linked every 4 hours during 24 hours. Crosslinking was performed by adding $12 \mathrm{~mL}$ of $1 \%$ formaldehyde solution (Sigma) at room temperature for 10 minutes. Then the reaction was quenched by adding glycine (Sigma) to $125 \mathrm{mM}$ final concentration. Afterwards cells were washed twice with PBS, and scraped after addition of $2 \mathrm{~mL}$ of weak lysis buffer containing $150 \mathrm{mM} \mathrm{NaCl}$, 20 mM EDTA pH 8, 50 mM Tris pH 8, $0.5 \%$ Nonidet P-40 (NP-40), 1 \% Triton X100 and protease inhibitor cocktail (Roche). The cell lysate was centrifuged at 12000 $\mathrm{x} g$ for 2 minutes at $4{ }^{\circ} \mathrm{C}$. The resulting nuclear pellet was resuspended in $1 \mathrm{~mL}$ weak lysis buffer, and centrifuged once more at $12000 \mathrm{xg}$ for 2 minutes at $4{ }^{\circ} \mathrm{C}$. The supernatant was discarded and the nuclear pellet was snap frozen in liquid nitrogen. 
Subsequently the nuclear pellet was resuspended in $300 \mu \mathrm{L}$ of nuclear lysis buffer (50 $\mathrm{mM}$ Tris $\mathrm{pH} 8,10 \mathrm{mM}$ EDTA, $1 \%$ SDS and protease inhibitor cocktail), incubated at $4{ }^{\circ} \mathrm{C}$ for 15 minutes with constant rotation, and sonicated using a Biorupter Plus (Diagenode) for 30 cycles at 30 seconds ON/OFF at high power. The sample was then centrifuged at $16000 \mathrm{x} g$ for 5 minutes at $8{ }^{\circ} \mathrm{C}$, the supernatant containing sheared chromatin was taken and diluted by adding $900 \mu \mathrm{L}$ of Immunoprecipitation buffer containing $150 \mathrm{mM} \mathrm{NaCl}, 1 \% \mathrm{NP}-40,0.5 \%$ sodium deoxycholate, $0.1 \%$ SDS, 50 $\mathrm{mM}$ Tris-HCl pH8, $20 \mathrm{mM}$ EDTA and protease inhibitor cocktail (Roche).

The diluted chromatin ( $20 \mu \mathrm{g}$ ) was pre-cleared with $20 \mu \mathrm{L}$ of ChIP- Grade Protein G Magnetic Beads (Cell Signaling Technology) for 1 hour with constant rotation at $4{ }^{\circ} \mathrm{C}$. The sample was placed onto a magnetic field to pull the magnetic beads to the side of the tube, and the supernatant containing pre-cleared chromatin was carefully taken. For the input sample, $10 \%$ of the supernatant was removed, transferred to a new tube and store at $-20{ }^{\circ} \mathrm{C}$ until further use.

For immunoprecipitation, pre-cleared chromatin was diluted once more with immunoprecipitation buffer to a final volume of $2 \mathrm{~mL}$. Pre-cleared chromatin was then incubated with $10 \mu \mathrm{g}$ of anti-E2F1 rabbit antibody (Cell Signaling Technology) at 4 ${ }^{\circ} \mathrm{C}$ with constant rotation overnight. $10 \mu \mathrm{g}$ Normal Rabbit IgG (Cell Signaling Technology) were added to negative control samples.

After antibody incubation, $30 \mu \mathrm{L}$ of ChIP- Grade Protein G Magnetic Beads (Cell Signaling Technology) were added to the antibody/antigen/chromatin complex, and incubated at $4{ }^{\circ} \mathrm{C}$ for 2 hours with constant rotation. Subsequently, the Protein $\mathrm{G}$ Magnetic Beads/antibody/antigen/chromatin complexes were pelleted by placing the tube into a magnetic separation rack. The pellet was washed 3 times at $4{ }^{\circ} \mathrm{C}$ with $1 \mathrm{~mL}$ 
of low salt buffer (100 mM Tris- $\mathrm{HCl} \mathrm{pH}$ 8, $1 \%$ NP-40, $1 \%$ sodium deoxycholate, 20 $\mathrm{mM}$ EDTA and protease inhibitor cocktail), followed by one wash at $4{ }^{\circ} \mathrm{C}$ with $1 \mathrm{~mL}$ of high salt buffer $(500 \mathrm{mM} \mathrm{NaCl}, 100 \mathrm{mM}$ Tris-HCl pH8, $1 \% \mathrm{NP}-40,1 \%$ sodium deoxycholate, $20 \mathrm{mM}$ EDTA and protease inhibitor cocktail).

Finally, the pellet was resuspended in $150 \mu \mathrm{L}$ of elution buffer $(5 \mathrm{Mm}$ Tris/ $\mathrm{HCl}, \mathrm{pH}$ 8.5), and incubated for 30 minutes at $65^{\circ} \mathrm{C}$ with gentle vortexing to elute chromatin from antibody/Protein G Magnetic Beads. All samples including the input sample were incubated with $0.1 \mu \mathrm{g} / \mu \mathrm{L}$ RNAse A (Sigma) during 45 minutes at $37{ }^{\circ} \mathrm{C}$. Crosslinks were reversed by 2 hours incubation at $65^{\circ} \mathrm{C}$ in $200 \mathrm{mM} \mathrm{NaCl}$ and $0.2 \mu \mathrm{g} / \mu \mathrm{L}$ of Proteinase K (Ambion, Life technologies). DNA purification was performed using DNA spin columns (Cell Signaling Technology 11137S), and DNA was eluted in 60 $\mu \mathrm{L}$ of elution buffer. The samples were then ready to be amplified by qRT-PCR. 


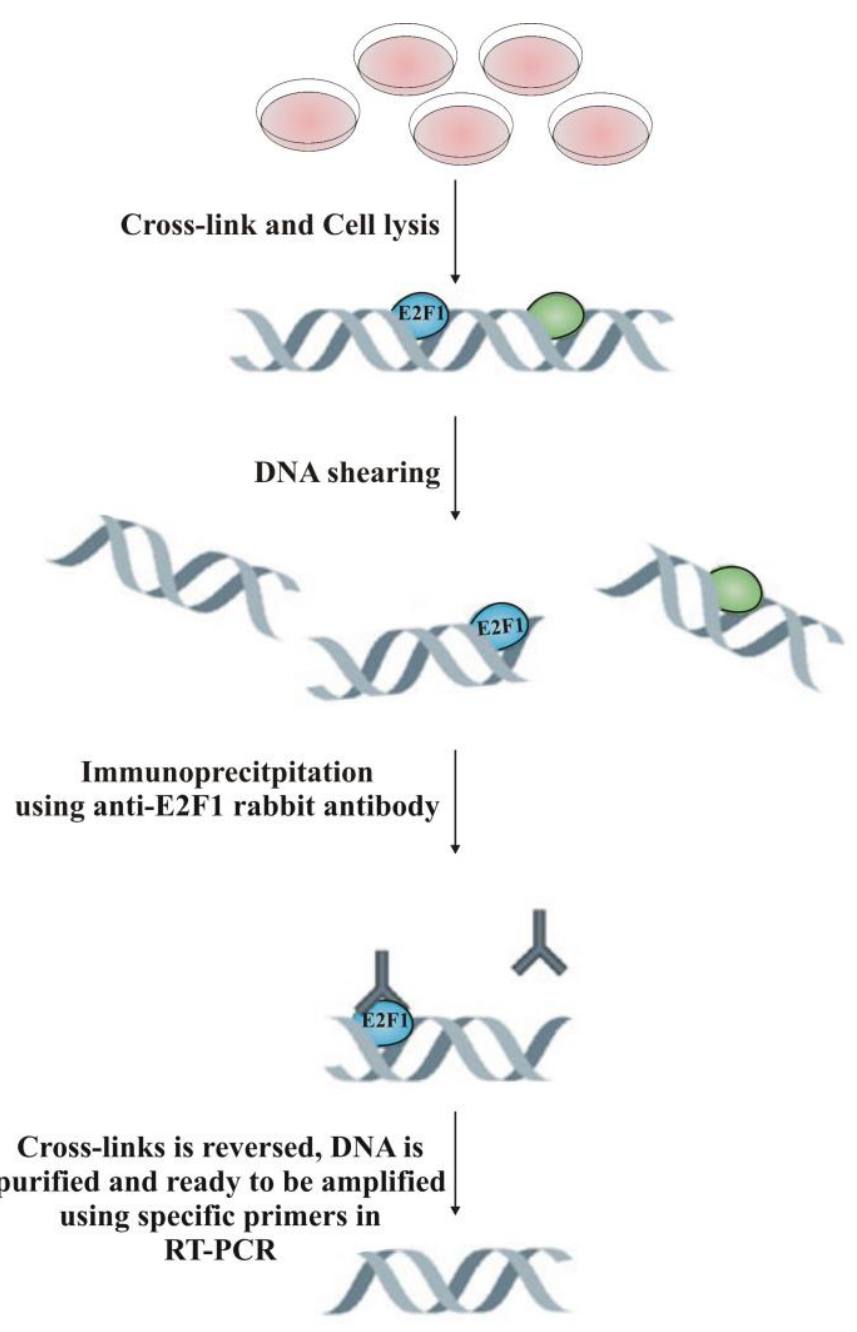

Figure 7. E2F1-Kv10.1 promoter interaction using ChIP assay. To define the temporal relationship of interaction between $\mathrm{E} 2 \mathrm{~F} 1-\mathrm{Kv} 10.1$ promoter, cells progressing through specific phases of the cell cycle were fixed with formaldehyde, lysed and the isolated chromatin was fragmented using sonication. The chromatin was immunoprecipitated using a specific antibody targeting the transcription factor E2F1. Thus, the DNA sequences that were associated with E2F1 were enriched after immunoprecipitation. The E2F1-DNA cross-links were reversed, and the DNA was purified and used to detect Kv10.1 promoter sequence enrichment by Real-Time PCR. Adapted figure from Farnham (2009). 


\subsection{Quantitative Real Time PCR}

\subsubsection{TaqMan assay (fluorescent donor: quencher hybridization)}

Reverse transcribed cDNA was taken as a template for qRT- PCR in order to determine gene expression. qRT-PCR was performed using specific TaqMan sets (Table 5) in a LightCycler 480 (Roche Applied Science) detection system.

\begin{tabular}{|c|c|c|}
\hline $\begin{array}{c}\text { Name } \\
\text { Primer/Probe }\end{array}$ & Sequence 5'- 3' & Gene \\
\hline hTfR-Fw (Sigma) & TTGAGAAAACAATGCAAAATGTG & $\begin{array}{c}\text { Human Transferrin } \\
\text { Receptor }\end{array}$ \\
\hline hTfR-Rv (Sigma) & CCCAGTTGCTGTCCTGATATAGA & $\begin{array}{c}\text { Human Transferrin } \\
\text { Receptor }\end{array}$ \\
\hline $\begin{array}{c}\text { hTfR-Probe } \\
\text { UPL \# } 61 \text { (Roche) }\end{array}$ & FAM CTGGGCAA Dark Quencher Dye & $\begin{array}{c}\text { Human Transferrin } \\
\text { Receptor }\end{array}$ \\
\hline $\begin{array}{c}\text { hGAPDH-Fw } \\
\text { (Sigma) }\end{array}$ & AGCCACATCGCTCAGACAC & Human GAPDH \\
\hline $\begin{array}{l}\text { hGAPDH-Rv } \\
\text { (Sigma) }\end{array}$ & GCCCAATACGACCAAATCC & Human GAPDH \\
\hline $\begin{array}{l}\text { hGAPDH-Probe } \\
\text { UPL \# } 61 \text { (Roche) }\end{array}$ & FAM TGGGGAAG Dark Quencher Dye & Human GAPDH \\
\hline $\begin{array}{l}\text { hKv10.1-Fw } \\
\text { (Sigma) }\end{array}$ & TGAGGTGGTGGCCATTCTA & Human Kv10.1 \\
\hline $\begin{array}{c}\text { hKv10.1-Rv } \\
\text { (Sigma) }\end{array}$ & GGCCCTAACATTGGCACA & Human Kv10.1 \\
\hline $\begin{array}{l}\text { hKv10.1-Probe } \\
\text { UPL \# } 61 \text { (Roche) }\end{array}$ & FAM TTGCCCAG Dark Quencher Dye & Human Kv10.1 \\
\hline hE2F1-Fw (Sigma) & TCCAAGAACCACATCCAGTG & Human E2F1 \\
\hline
\end{tabular}




\begin{tabular}{ccc}
\hline hE2F1-Rv (Sigma) & CTGGGTCAACCCCTCAAG & Human E2F1 \\
\hline hE2F1-Probe & FAM CAGCCACA Dark Quencher Dye & Human E2F1 \\
UPL \# 61 (Roche) & & \\
\hline
\end{tabular}

Table 5. TaqMan sets, primers and probes used for qRT-PCR

For the qRT-PCR reaction, $2 \mu \mathrm{L}$ of cDNA were mixed with $1 \mu \mathrm{L}$ of $100 \mu \mathrm{M}$ primer mix, $0.1 \mu \mathrm{L}$ of $10 \mu \mathrm{M}$ Universal Probe Library probe (Roche), and $0.1 \mu \mathrm{L}$ UracilDNA-glycosylase 2U/ $\mu \mathrm{L}$ (New England BioLabs). Afterwards, $5 \mu \mathrm{L}$ of ready-to-use hot-star PCR mix (Roche) containing FastStart Taq DNA Polymerase, reaction buffer, and dNTPmix were added. LightCycler® 480 (Roche Applied Science) detection system was programmed for 45 cycles at $50{ }^{\circ} \mathrm{C}$ for 2 minutes, 10 minutes at $95^{\circ} \mathrm{C}, 30$ seconds at $60{ }^{\circ} \mathrm{C}$ followed by 10 seconds at $40{ }^{\circ} \mathrm{C}$. Relative quantification of the samples was done using $\Delta \Delta \mathrm{Ct}$ method (Livak \& Schmittgen, 2001), human housekeeping genes transferrin receptor and GAPDH were used to normalize the samples.

\subsubsection{SYBR Green intercalating dye}

DNA from ChIP assays was used as a template for qRT-PCR in order to amplify E2F1 responsive promoter regions. The primer sets used are described in Table 6.

\begin{tabular}{ccc}
\hline Primer & Sequence 5' - 3' & Amplified \\
& & promoter region \\
\hline hGAPDH-Fw & CCGGGAGAAGCTGAGTCATG & hGAPDH \\
(Metabion) & (Shema, Tirosh et al. 2008) & \\
\hline hGAPDH-Rv & TTTGCGGTGGAAATGTCCTT & hGAPDH \\
(Metabion) & (Shema, Tirosh et al. 2008) & \\
\hline
\end{tabular}




\begin{tabular}{ccc}
\hline $\begin{array}{c}\text { hKCNH1-Fw } \\
\text { (Metabion) }\end{array}$ & CGA GGG TAG CAG CCA GA & hKCNH1 \\
\hline hKCNH1-Rv & CTGGCGCGGCTTCTTAC & hKCNH1 \\
(Metabion) & & \\
\hline hCyclin A2-Fw & CTGCTCAGTTTCCTTTGGTTTACC & hCyclin A2 \\
(Metabion) & (Docquier, Augereau et al. 2012) & \\
\hline hCyclin A2-Rv & CAAAGACGCCCAGAGATGCAG & hCyclin A2 \\
(Metabion) & (Docquier, Augereau et al. 2012) & \\
& & \\
\end{tabular}

\section{Table 6. Primer sets used for ChIP/qRT-PCR}

For the qRT-PCR reaction, $2 \mu \mathrm{L}$ of DNA (immunoprecipitated chromatin) were mixed with $1 \mu \mathrm{L}$ of $3 \mu \mathrm{M}$ primer mix. Then, $10 \mu \mathrm{L}$ of the PCR mixture (Roche) containing SYBR Green 1 Dye, AmpliTaq Gold DNA Polymerase LD, dNTPs with dUTP/dTTP were added to the reaction mix. Amplification was carried out in a LightCycler 480 (Roche Applied Science) detection system for 29 cycles at $95^{\circ} \mathrm{C}$ for $30 \mathrm{~s}, 40 \mathrm{~s}$ at 72 ${ }^{\circ} \mathrm{C}$, followed by a final 5 minutes extension at $72{ }^{\circ} \mathrm{C}$. Quantification of the samples was done using $\Delta \Delta \mathrm{Ct}$ method (Livak and Schmittgen 2001). GAPDH, a non-E2F1 regulated gene was used to normalize the samples. Fold enrichment was reported after further normalization relative to IgG signal.

\subsection{Biochemistry}

\subsubsection{Protein extraction}

Cells were harvested by trypsinization and washed once with PBS. After centrifugation, the cell pellet was resuspended and incubated for 30 minutes in nondenaturating lysis buffer containing $1 \%$ Triton X-100, $50 \mathrm{mM}$ Tris-HCl, $300 \mathrm{mM}$ 
$\mathrm{NaCl}, 5 \mathrm{mM}$ EDTA and protease inhibitor cocktail (Roche). The cell lysate was then centrifuged for 15 minutes at $16000 \mathrm{x} g$, the supernatant was recovered and the protein concentration was measured using BCA Protein Assay Kit (Thermo Scientific) according to the manufacturer's instructions.

\subsubsection{Immunoprecipitation}

The samples were immunoprecipitated due to the low amount of Kv10.1 endogenous levels. After protein quantification, $400 \mu \mathrm{L}$ of cell lysate containing $700 \mu \mathrm{g}$ of total protein were incubated for 1 hour at $4{ }^{\circ} \mathrm{C}$ with protein $\mathrm{G}$ Magnetic Beads (New England BioLabs) to preclear the sample. Then $3 \mu \mathrm{L}$ of anti-Kv10.1 monoclonal antibody (Kv10.1-33.mAb) were added to the precleared sample and incubated for 1 hour at $4{ }^{\circ} \mathrm{C}$, followed by the addition of $30 \mu \mathrm{L}$ of protein $\mathrm{G}$ magnetic beads (New England BioLabs) and 1 hour incubation. Then, Protein G Magnetic Beads/ antibody/Kv10.1 complexes were pelleted by placing the sample into a magnetic separation rack. The pellet was washed 3 times at $4{ }^{\circ} \mathrm{C}$ with $500 \mu \mathrm{L}$ of Immunoprecipitation buffer $(0.1 \%$ Triton $\mathrm{X}-100,50 \mathrm{mM}$ Tris- $\mathrm{HCl}, 300 \mathrm{mM} \mathrm{NaCl}$, $5 \mathrm{mM}$ EDTA and protease inhibitor cocktail). The pellet was resuspended in $16.25 \mu \mathrm{L}$ of TBS buffer (20 mM Tris, $150 \mathrm{mM} \mathrm{NaCl}, \mathrm{pH}$ 7.6), $2.5 \mu \mathrm{L}$ NuPAGE® reducing agent (invitrogen) and 6.25 $\mu$ L NuPAGE LDS Sample buffer (invitrogen). Finally the resuspended pellet was incubated for 10 minutes at $70{ }^{\circ} \mathrm{C}$ to elute $\mathrm{Kv} 10.1$ protein from antibody/Protein G Magnetic Beads.

\subsubsection{SDS-PAGE}

In order to disrupt protein secondary structure, and allow proteins to migrate depending on the mass to charge ratio after applying voltage across the SDSpolyacrylamide gel, $3 \mu \mathrm{L}$ NuPAGE reducing agent (Invitrogen), and $7.5 \mu \mathrm{L}$ NuPAGE 
LDS Sample buffer (Invitrogen) were added to the samples (100 $\mu \mathrm{g}$ total protein) to a final volume of $30 \mu \mathrm{L}$. Then the reduced samples were incubated at $70{ }^{\circ} \mathrm{C}$ for 10 minutes.

The denaturated samples were loaded into 3-8 \% NuPAGE Novex Tris-Acetate Mini Gels (Invitrogen) to resolve proteins of large molecular weight, or into 4-12\% NuPAGE Novex Bis-Tris Mini Gels (Invitrogen) to resolve small to medium molecular weight proteins.

\subsubsection{Western blot}

Once the proteins were separated by SDS-PAGE, the SDS-polyacrylamide gel was set in direct contact with the nitrocellulose membrane (GE Healthcare), then placed in a chamber filled with the transfer buffer containing $10 \mathrm{mM} \mathrm{NaHCO}, 3 \mathrm{mM} \mathrm{Na} \mathrm{CO}_{3}$, $0.01 \%$ SDS and $20 \%$ methanol. In order to allow the proteins to be transferred to the membrane, a voltage gradient was applied from $10 \mathrm{~V}$ to $50 \mathrm{~V}$ with stepwise increments of $10 \mathrm{~V}$ every ten minutes and the final step at $50 \mathrm{~V}$ for $30 \mathrm{~min}$. Then, the membrane was rinsed with deionized water and dried for 2 hours at room temperature.

The membrane was rehydrated with deionized water and treated with Blot signal enhancer (Thermo Scientific) according to the manufacturer's instructions. The membrane was then incubated for 1 hour in blocking buffer containing casein and TBS-T (0.1\% Casein, $20 \mathrm{mM}$ Tris, $150 \mathrm{mM} \mathrm{NaCl}$ and $0.05 \%$ Tween 20), followed by overnight incubation at $4{ }^{\circ} \mathrm{C}$ with primary antibody diluted in blocking buffer (Table 7). After 5 washes with deionized water and 5 minutes incubation with TBS$\mathrm{T}$, the membrane was incubated for 45 minutes with horseradish peroxidase (HRP) conjugated secondary antibody diluted in blocking buffer (Table 7). Then the membrane was washed 7 times with deionized water and incubated for 5 minutes with 
TBS-T. At last, the chemiluminescent HRP substrate (Millipore) was applied to the blot for 5 minutes, thus the chemiluminescence reaction was catalyzed by the peroxidase conjugated to the secondary antibody, leading to light emission. The emitted light was detected with a ChemiDoc XRS system (Bio-Rad), the image acquisition was done using Quantity One 1-D Analysis Software v4.6.9 (Bio-Rad). For imaging processing analysis FIJI software was used (Schindelin 2008).

\begin{tabular}{|c|c|c|c|}
\hline Antibody & $\begin{array}{c}\text { Host Species/ } \\
\text { Clonality }\end{array}$ & Dilution & Manufacturer \\
\hline Kv10.1-9391 & Rabbit/polyclonal & $1: 1500$ & $\begin{array}{l}\text { (Weber, Mello de } \\
\text { Queiroz et al. 2006) }\end{array}$ \\
\hline E2F1 & Rabbit/polyclonal & $1: 1000$ & Cell signaling \\
\hline $\mathrm{Rb}(4 \mathrm{H} 1)$ & Mouse/monoclonal & $1: 2000$ & Cell signaling \\
\hline Cyclin A (BF683) & Mouse/monoclonal & $1: 2000$ & Cell signaling \\
\hline Calnexin & Rabbit/polyclonal & $1: 1000$ & Enzo life Sciences \\
\hline Actin & Goat/polyclonal & $1: 1000$ & Santa Cruz \\
\hline $\begin{array}{l}\text { ECL Anti-Rabbit } \\
\text { IgG, Horseradish } \\
\text { Peroxidase Linked }\end{array}$ & Donkey/polyclonal & $1: 10000$ & GE Healthcare \\
\hline $\begin{array}{l}\text { ECL Anti-Mouse } \\
\text { IgG, Horseradish } \\
\text { Peroxidase Linked }\end{array}$ & Sheep/polyclonal & $1: 10000$ & GE Healthcare \\
\hline $\begin{array}{c}\text { Anti-Goat IgG } \\
\text { (H+L)-HRP } \\
\text { Conjugate }\end{array}$ & Rabbit/polyclonal & $1: 10000$ & BIO-RAD \\
\hline
\end{tabular}

Table 7. Primary and secondary antibodies used for western blot 


\subsection{Immunostaining}

\subsubsection{Immunocytochemistry}

Cells were plated on poly-L-lysine coated coverslips (Menzel), synchronized using a double thymidine block protocol, and starting at the release time different coverslips were fixed in 4 hours intervals during 24 hours. Cells were fixed using $10 \%$ formalin solution (Sigma) at $4{ }^{\circ} \mathrm{C}$ for 10 minutes, washed 3 times with PBS, and permeabilized with $0.5 \%$ Triton X-100 (Sigma) in PBS for 5 minutes. Afterwards, cells were washed 3 times with PBST (0.05\% Tween 20 (Sigma) in PBS), blocked with $10 \%$ BSA (Sigma) in PBST for 1 hour, and incubated with primary antibodies diluted in blocking solution overnight at $4{ }^{\circ} \mathrm{C}$ (Table 8).

Cells were then rinsed 3 times, incubated for 1 hour at room temperature with secondary antibodies diluted in blocking solution (Table 8), and washed again 3 times. At last, the nuclei were counter- stained with 1:1000 dilution of TO-PRO-3 (Invitrogen) in PBST, the coverslips were mounted on a glass slide (Menzel) using Prolong Gold antifade reagent with DAPI (Invitrogen). Confocal images were taken using LSM 510 Meta laser scanning confocal microscope (Zeiss), ZEN (Zeiss) software was used for image acquisition, and Imaging processing was done using the image analysis software FIJI (Schindelin 2008).

\begin{tabular}{cccc}
\hline Antibody & Host Species/ & Dilution & Manufacturer \\
& Clonality & & \\
\hline Kv10.1-62 & Mouse/monoclonal & $1: 1000$ & (Hemmerlein, \\
& & & Weseloh et al. 2006)
\end{tabular}




\begin{tabular}{clcc}
\hline Cyclin B1 & Rabbit/polyclonal & $1: 50$ & Cell Signaling \\
\hline $\begin{array}{c}\text { Alexa Fluor 488 anti- } \\
\text { rabbit IgG }(\mathrm{H}+\mathrm{L})\end{array}$ & Goat/polyclonal & $1: 1000$ & Invitrogen \\
\hline $\begin{array}{c}\text { Alexa Fluor 546 anti- } \\
\text { mouse IgG }(\mathrm{H}+\mathrm{L})\end{array}$ & Goat/polyclonal & $1: 1000$ & Invitrogen \\
\hline
\end{tabular}

Table 8. Primary and secondary antibodies used for Immunocytochemistry

\subsubsection{Immunohistochemistry}

Tissue samples were provided by Dr. Alonso Barrantes (Department of Neuropathology, Universitätsmedizin Göttingen). Tissue sections were deparaffined using xylene and rehydrated by decreasing ethanol dilutions (from $100 \%$ to $90 \%$ to $70 \%$ to $0 \%$ ) for 5 minutes each step. Afterwards, the tissue sections were incubated for 30 minutes at $90^{\circ} \mathrm{C}$ in $10 \mathrm{mM}$ citrate buffer for antigen retrieval. Then, the sections were allowed to cool down for $1 \mathrm{~h}$ at room temperature, and washed with $0.05 \%$ Tween 20 (Sigma) in TBS. Blocking was performed using $10 \%$ BSA (Sigma) diluted in TBS and $0.05 \%$ Tween 20 (Sigma). The tissue sections were incubated overnight at $4{ }^{\circ} \mathrm{C}$ with primary antibody (Table 9) diluted in blocking solution, washed 3 times, and incubated for 1 hour at room temperature with secondary antibody (Table 9) diluted in blocking solution. After washing, the tissue sections were incubated with 1 $\mu \mathrm{L}$ of TO-PRO-3 (Invitrogen) diluted in $1 \mathrm{~mL}$ of blocking solution to counter- stain nuclei. Finally, the sections were mounted using Prolong Gold antifade reagent with DAPI (Invitrogen). Confocal images were taken using LSM 510 Meta laser scanning confocal microscope (Zeiss), ZEN (Zeiss) software was used for image acquisition, and image processing was done using the image analysis software FIJI (Schindelin 2008). 


\begin{tabular}{clcc}
\hline Antibody & Host Species/ & Dilution & Manufacturer \\
& \multicolumn{1}{c}{ Clonality } & & \\
\hline Kv10.1-62 & Mouse/monoclonal & $1: 100$ & (Hemmerlein, \\
& & & Weseloh et al. 2006) \\
\hline Cyclin B1 & Rabbit/polyclonal & $1: 200$ & Acris \\
\hline $\begin{array}{c}\text { Alexa Fluor 488 anti- } \\
\text { rabbit IgG (H+L) }\end{array}$ & Goat/polyclonal & $1: 1000$ & Invitrogen \\
\hline $\begin{array}{c}\text { Alexa Fluor 546 anti- } \\
\text { mouse IgG (H+L) }\end{array}$ & Goat/polyclonal & $1: 1000$ & Invitrogen \\
\hline
\end{tabular}

Table 9. Primary and secondary antibodies used for Immunohistochemistry 


\section{RESULTS}

\subsection{Kv10.1 expression in HeLa cells}

Kv10.1 expression has been reported to be widespread in clinical samples of solid tumors (Patt, Preussat et al. 2004, Hemmerlein, Weseloh et al. 2006, Mello de Queiroz, Suarez-Kurtz et al. 2006, Ding, Luo et al. 2007, Ding, Yan et al. 2007, Ding, Wang et al. 2008, Asher, Khan et al. 2010, Menendez, Villaronga et al. 2012, del Pliego, Aguirre-Benitez et al. 2013), as well as in leukemias (Agarwal, Griesinger et al. 2010). Kv10.1 expression in tumor tissues has been proposed as a prognosis marker, as gene amplification is shown to be associated with poor survival in leukemia, colon and ovarian cancer patients (Ding, Yan et al. 2007, Agarwal, Griesinger et al. 2010, Asher, Khan et al. 2010, Rodriguez-Rasgado, Acuna-Macias et al. 2012). Apart from that, Kv10.1 expression in normal non-neural tissue has been detected in low levels, and only in restricted populations of cells (Hemmerlein, Weseloh et al. 2006). Kv10.1 channel expression also appears to be increased upon mitogen factor stimulation (Borowiec, Hague et al. 2007), favors cell proliferation and tumor progression (Pardo, del Camino et al. 1999, Weber, Mello de Queiroz et al. 2006, Downie, Sanchez et al. 2008). It is believed that tumor cells expressing Kv10.1 acquire selective advantages that allow them to sustain chronic proliferation. Nevertheless, neither the dependency of Kv10.1 expression kinetics on the cell cycle, nor the mechanism underlying Kv10.1 expression in cancer cells are fully understood. Through this study we attempted to address these matters using HeLa cells as a model system. Those cells are derived from a cervical carcinoma, and are one of the most commonly used cell lines in mammalian cell cycle research. HeLa cells can be effectively synchronized by double thymidine block, and gene expression through the cell cycle can be monitored after 
releasing them. Moreover, endogenous Kv10.1 expression has been detected in HeLa cells by RT-PCR (Pardo, del Camino et al. 1999).

Subcellular localization of Kv10.1 was determined in asynchronous population of growing HeLa cells. Immunostaining revealed that HeLa cells expressed Kv10.1 in a non-uniform fashion. Kv10.1 expression was enriched in the plasma membrane of cells showing chromosomal condensation, as well as in the cytoplasmic bridge of cells undergoing cytokinesis (Figure 8). Cells committed to mitosis show high cyclin BCdk1 complex activity, followed by nuclear envelope breakdown. At this point, compact chromosomes are formed during chromatin reorganization (Pines and Hunter 1991). To test whether Kv10.1 expression in HeLa cells is associated to mitosis, subcellular localization of Cyclin B1 together with the DNA pattern staining were used as markers for G2 and mitotic cells (Figure 9). Cyclin B1 accumulates in the cytoplasm of cells progressing from $S$ to $G 2$, shuttles to the nucleus and is concentrated near the condensed chromosomes during prophase and methaphase. Later, when cells progress to anaphase Cyclin B1 is degraded by the anaphase promoting complex, and the two daughter cells are divided (Pines and Hunter 1991, Pines and Hunter 1994, Porter and Donoghue 2003). Thus, Cells in G2 phase show cytoplasmic cyclin B1 and disaggregated chromatin, the G2/M boundary shows nuclear cyclin B1, and cells in late M phase display condensed chromosomes. Positive membrane staining for Kv10.1 expression was observed in cells with cytoplasmic Cyclin B1 staining (G2 phase; Figure 10B), but also high Kv10.1 expression was observed in the cell membrane during mitosis (Figure 10A), distinguishable by chromosomal condensation and nuclear localization of Cyclin B1 (Figure 9 and Figure 10). 


\section{Merge}
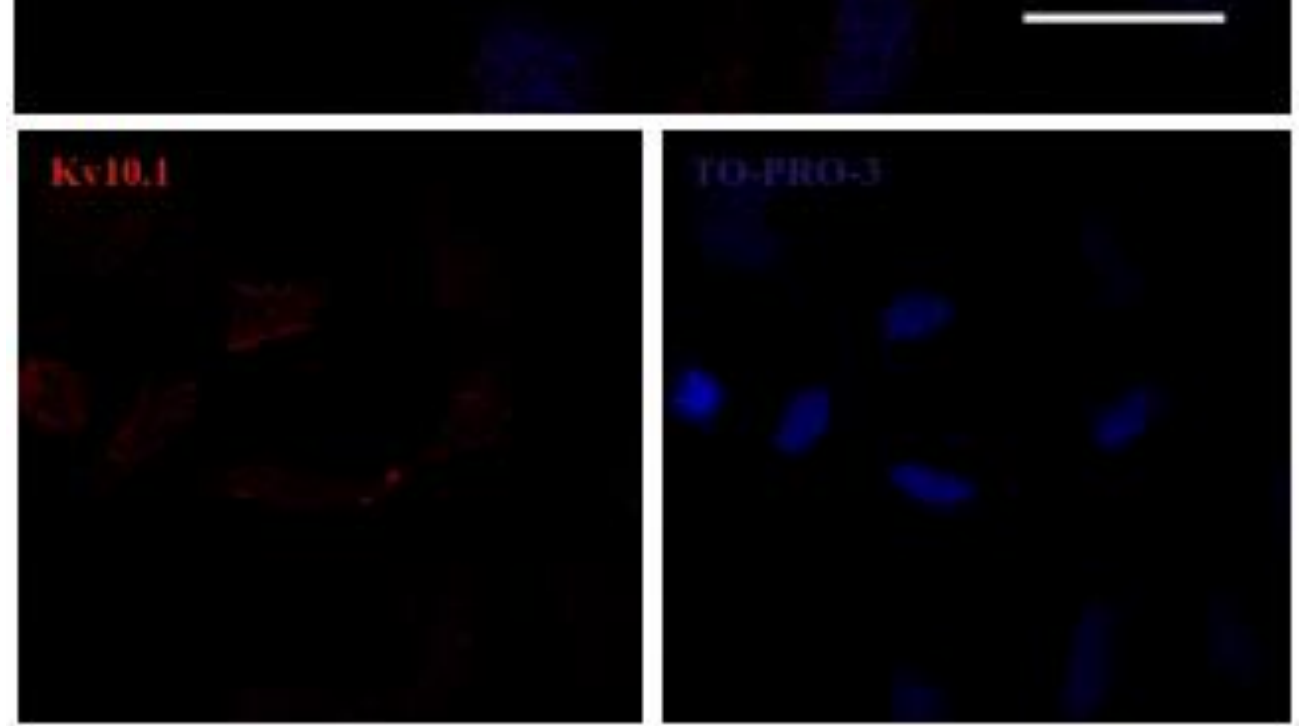

Figure 8. Subcellular localization of Kv10.1 in HeLa cells. HeLa cells were immunostained using Kv10.1-62.mAb. Kv10.1 membrane staining was not uniform in the population of cells, membrane staining was enriched in cells showing chromosomal condensation, as well as in the cytoplasmic bridge of cells undergoing cytokinesis. TO-PRO-3 was used to stain nucleic acids. Scale Bar $20 \mu \mathrm{m}$. 

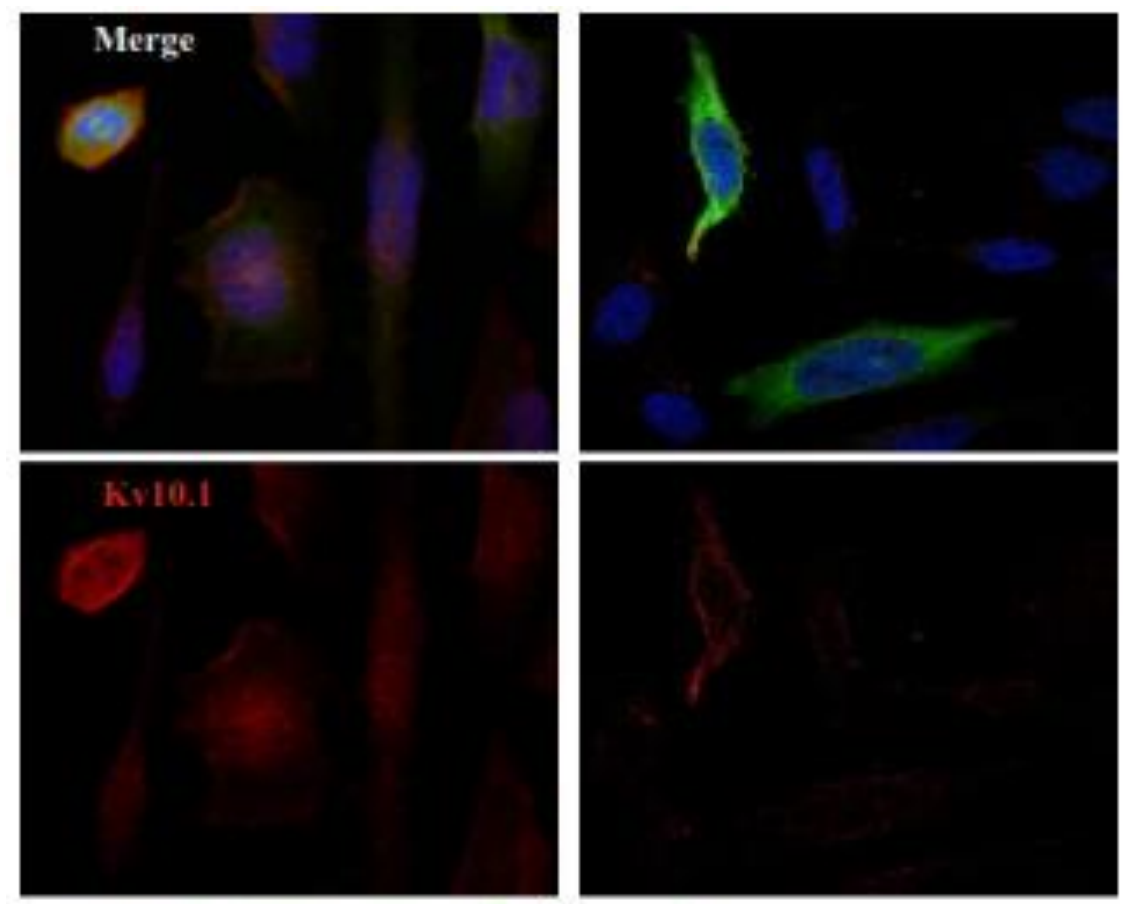

Cyclin B1
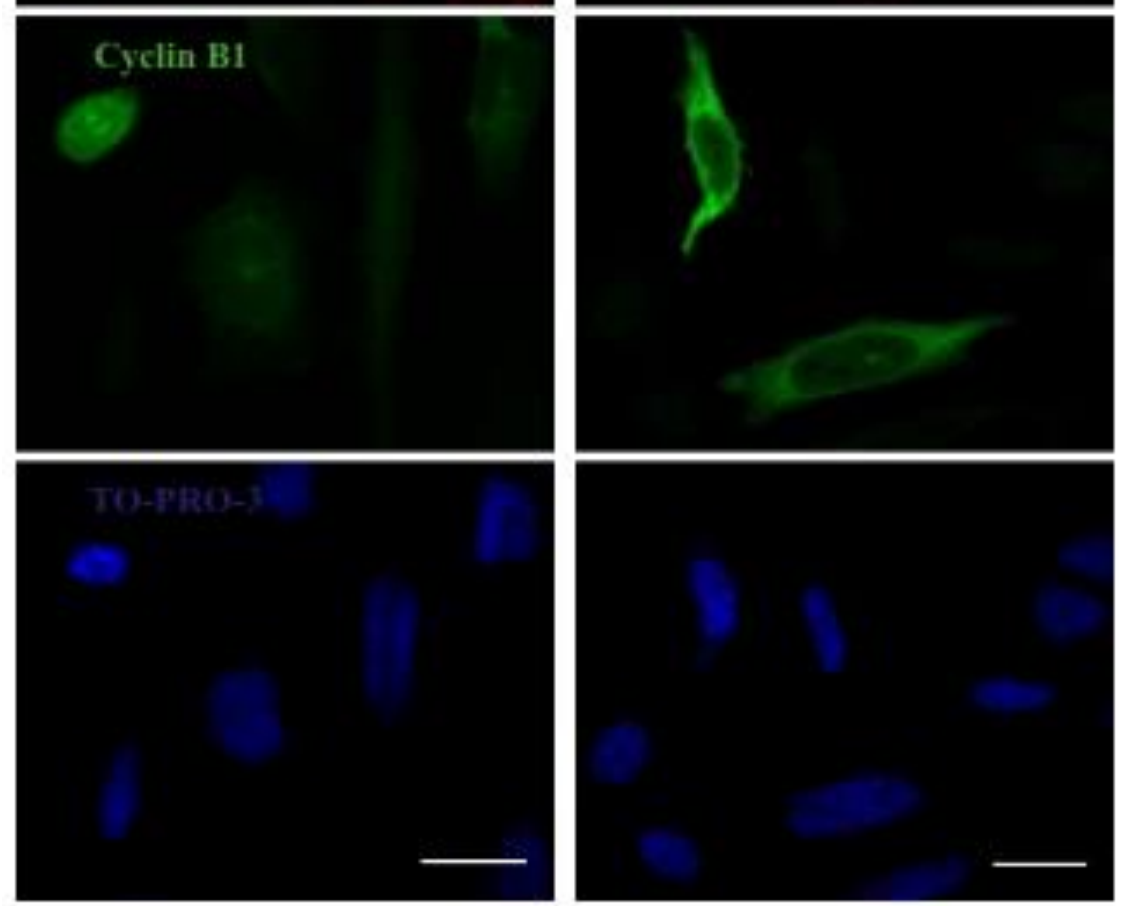

Figure 9. Kv10.1 expression and cyclin B1 subcellular localization in HeLa Cells. Cyclin B1 was localized in the cytoplasm of G2 cells, during mitosis Cyclin B1 localized to the nucleus, in association with condensed chromosomes. TO-PRO-3 staining showed the diffuse DNA during G2 and condensed chromosomes in metaphase. Kv10.1 membrane staining was enriched in Cyclin B1 positive cells. Scale Bar $20 \mu \mathrm{m}$. 

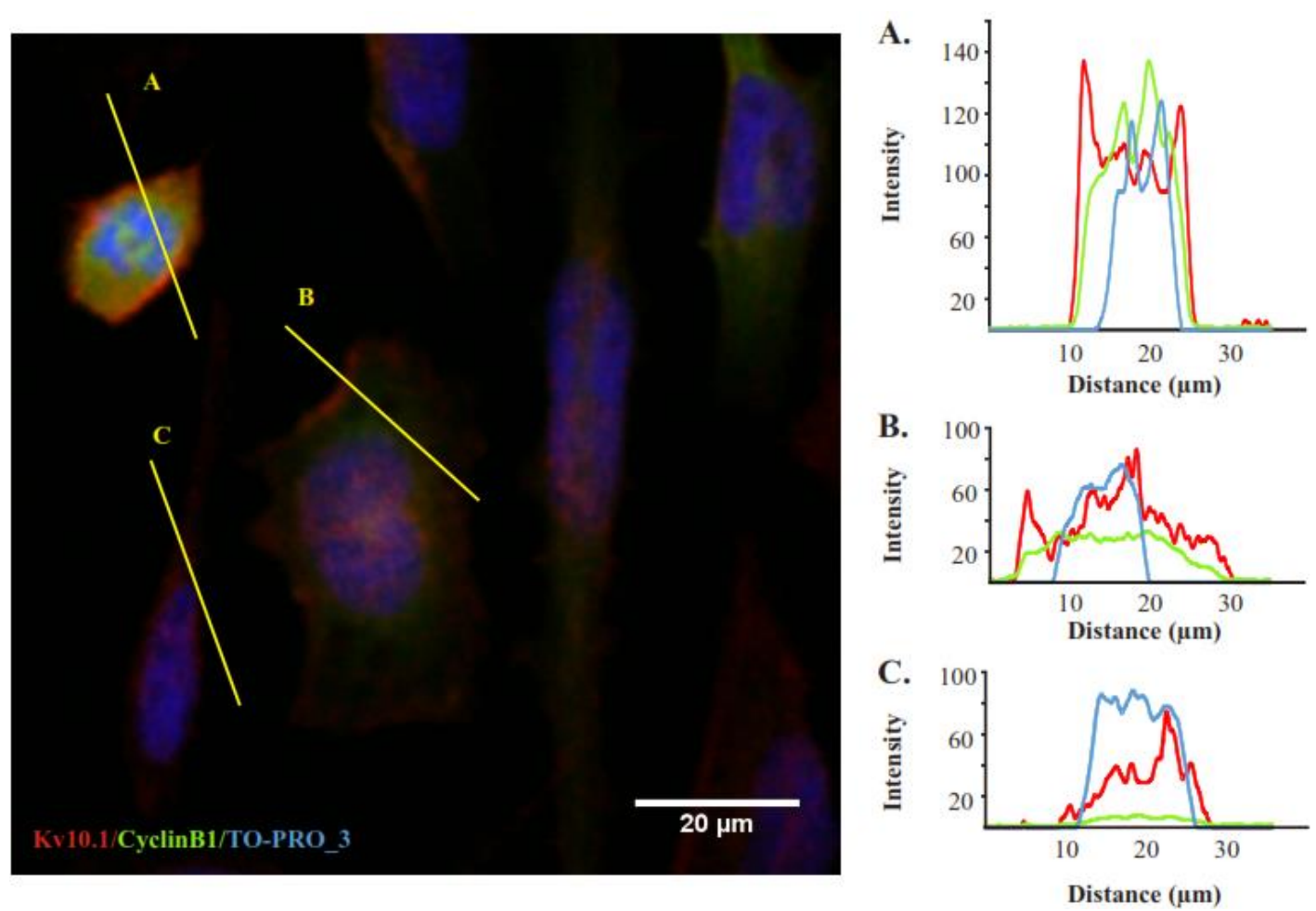

Figure 10. Kv10.1 expression in HeLa Cells has a temporal colocalization with Cyclin B1 expression. (A) Cells undergoing mitosis displayed condensed chromosomes and nuclear cyclin B1. These cells showed high Kv10.1 membrane expression. (B) Weaker membrane staining for Kv10.1 was also observed in late G2 cells, distinguishable for cytoplasmic and nuclear cyclin B1 signal. (C) Faint Kv10.1 membrane signal was observed in cyclin B1-negative cells. Imaging processing and intensity plot in A, B and C were done using the image analysis software FIJI.

\subsection{Dynamic expression of Kv10.1 along the cell cycle}

Immunocytochemistry experiments showed an enrichment of Kv10.1 expression in cells progressing through mitosis. To further determine whether Kv10.1 expression kinetics was associated to the cell cycle, HeLa cells were synchronized using a double thymidine block protocol (Figure 6). Then, every 4 hours after the releasing time, endogenous Kv10.1 expression levels were assessed by immunoprecipitation using 
Kv10.1-33.mAb and Western blot detection with a polyclonal antibody Kv10.1-9391

(Figure 12). Cell cycle analysis based on DNA content was performed to determine the cell cycle distribution after thymidine release (Figure 11). Propidium iodide (PI), a DNA fluorochrome, binds proportionally to the DNA present in the cell. When the PI stained cells pass through the flow cytometer's laser, the emitted light correlates with the amount of PI bound to the DNA, and therefore with the total amount of DNA in the cell. As a result, cells in G0/G1 have a uniform DNA content, whereas cells undergoing DNA replication (S phase) have more DNA and take up more PI. G2/M cells have then twice as much DNA as G0/G1, and therefore twice as much fluorescence intensity (Pozarowski and Darzynkiewicz 2004). Cell populations progressing through the different phases of the cell cycle are represented on frequency histograms (Figure 11 B, C and D). After thymidine treatment $(0 \mathrm{~h})$, cells were arrested at the G1/S border. Within the following 4 hours, the cell population progressed into $S$ phase, and a majority reached the G2/M phases after 8 hours. Simultaneously, endogenous Kv10.1 expression increased gradually and reached a peak at 12 hours, corresponding to a majority of the cells in early G1, after the first mitosis was completed (Figure 12 A and B). Then, Kv10.1 expression levels decreased markedly as the cells progressed through middle G1 (16 h) and reentered to S phase $(20 \mathrm{~h}$ and $24 \mathrm{~h})$. 
A. FACS analysis of cell cycle distributions in HeLa cells
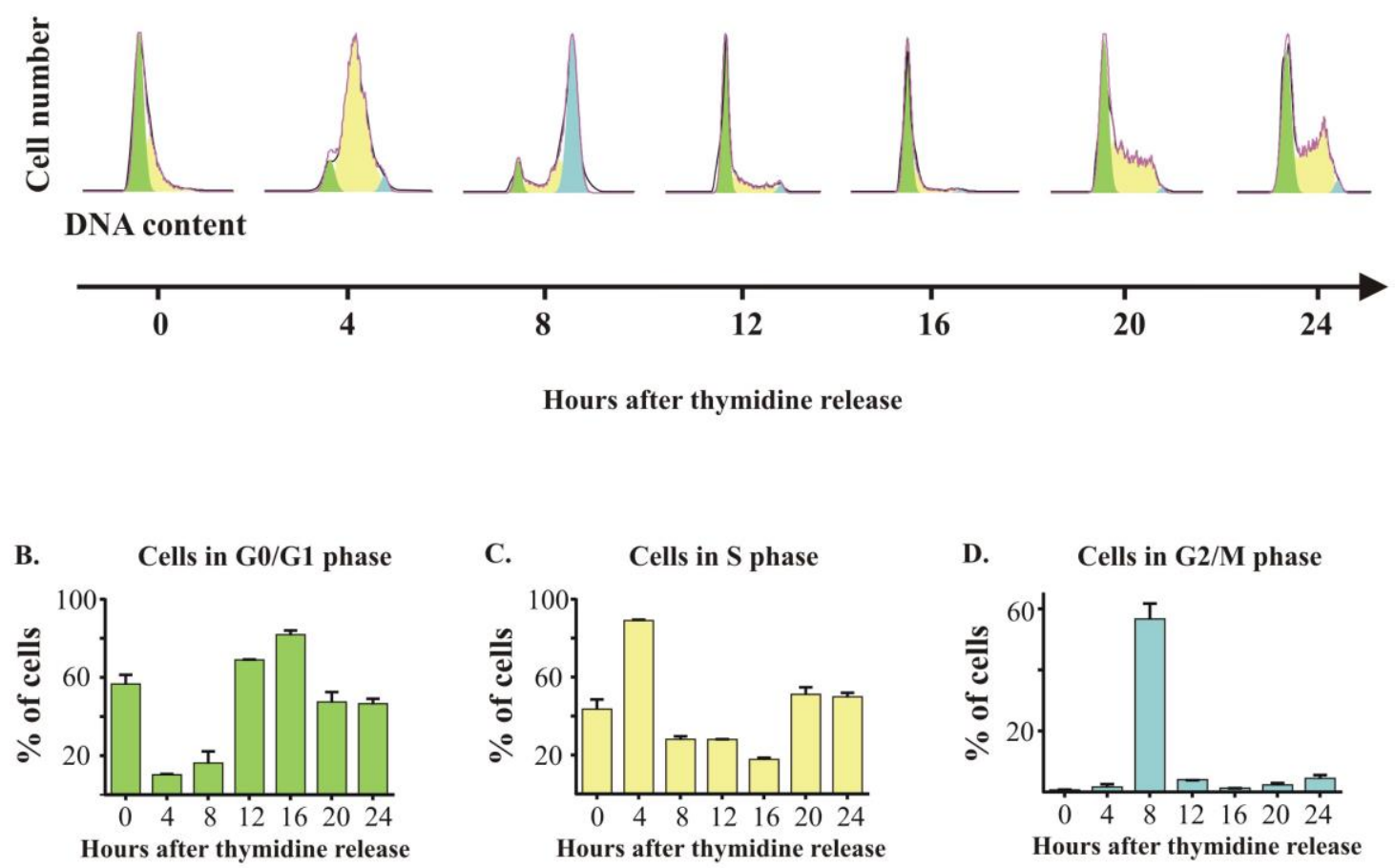

Figure 11. FACS analysis of synchronized HeLa cells using double thymidine

block protocol. (A) Cell cycle analysis based on PI staining, as a measure for DNA content, was performed to determine the cell cycle distribution after thymidine release. (B) Quantification of cells in G1/G0, (C) cells in S phase, and (D) cells in G2/M phase. FACS Diva software v5.0 (BD Biosciences) was used for data acquisition, and data processing was done with FlowJo v10.0.7 software (Tree Star).

E2F1 is a transcription factor known to control transcription of genes required for cell cycle progression in a time-specific manner (Takahashi, Rayman et al. 2000). E2F1 transcription factor has been proposed to influence Kv10.1 expression, owing to its active binding site on Kv10.1 promoter (Suckow 2003, Lin, Li et al. 2011). As expected, E2F1 expression levels changed through the cells cycle (Figure 12 A and C). Expression of E2F1 was maximal at the G1/S border (immediately at the time of release), and dropped thereafter as the cells progressed through $\mathrm{S}$ and $\mathrm{G} 2 / \mathrm{M}$ phases. 
Afterwards, E2F1 re-accumulated as the cells entered middle and late G1 phase. Retinoblastoma protein $(\mathrm{Rb})$ has been shown to regulate the $\mathrm{G} 1 / \mathrm{S}$ transition by binding to E2F1 and repressing its transcriptional activity (Rubin, Gall et al. 2005). Accordingly, Rb levels accumulated during G2/M and early G1 (Figure 12 A and D) where it represses E2F1 activity.

Taken together, these results strongly suggest that rather than showing a constitutive expression, the levels of Kv10.1 change periodically during the cell cycle with a maximum at the G2/M phase. The E2F1 expression levels also fluctuate periodically during the cell cycle. However, the E2F1 peak expression occurs at the G1/S border. 
A. Protein expression pattern in synchronized HeLa cells
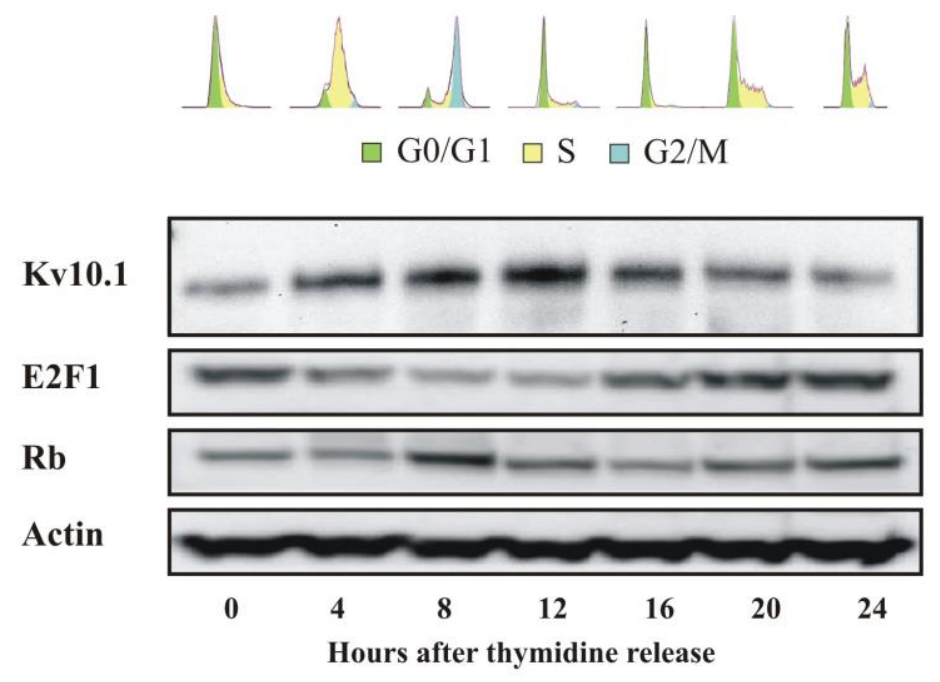

B.

Kv10.1

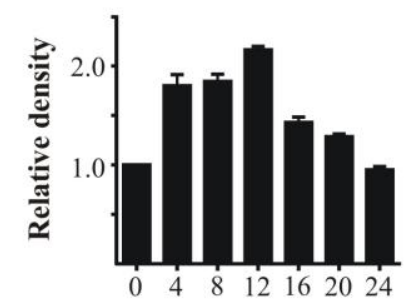

Hours after thymidine release
C.

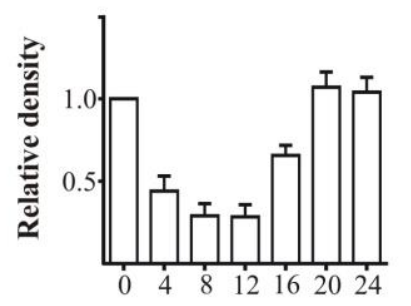

Hours after thymidine release
D.

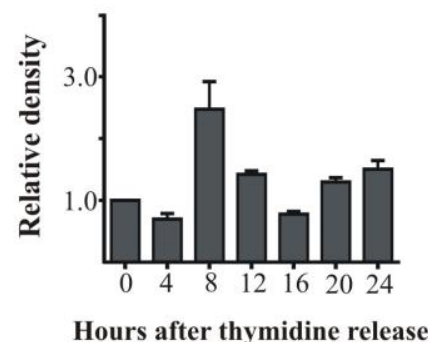

Figure 12. Kv10.1 expression pattern along the cell cycle in HeLa cells. (A)Western blot assay of Kv10.1, E2F1 transcription factor, and Retinoblastoma protein $(\mathrm{Rb})$ expression in thymidine synchronized HeLa cells. Kv10.1 was previously immunoprecipitated using anti-Kv10.1 clone 33 antibody. Expression of Actin was assessed as loading control. (B) Densitometry analysis of Kv10.1 protein expression during the cell cycle, data were normalized to time $0 \mathrm{~h}(\mathbf{C}$ and $\mathbf{D})$ Densitometry analysis of $\mathrm{E} 2 \mathrm{~F} 1$ and $\mathrm{Rb}$ protein expression relative to actin and time $0 \mathrm{~h}$. Data analysis was done using the image analysis software FIJI. 


\subsection{Kv10.1 regulation by $\mathrm{RB} / \mathrm{E} 2 \mathrm{~F} 1$ pathway}

Previous reports have identified the minimal promoter region of Kv10.1 and located an E2F1 binding site consensus sequence (Suckow 2003, Lin, Li et al. 2011). However, a transcriptional modulation by E2F1 had not been documented in vivo. To further explore regulation on Kv10.1 expression, E2F1 was overexpressed in asynchronous HeLa cells. Then, abundance of endogenous Kv10.1 protein was assessed by immunoprecipitation using Kv10.1-33.mAb and Western blot detection with a polyclonal antibody Kv10.1-9391. E2F1 overexpression resulted in an increase of the levels of Kv10.1. Human Papilloma Virus E7 oncoprotein (HPV-E7) is known to both disrupt the interaction between $\mathrm{Rb}$ and E2F1 and increase Kv10.1 expression (Diaz, Ceja-Ochoa et al. 2009). Overexpression of HPV-E7 induces E2F1 release and causes transcriptional activation of E2F1-responsive promoters (Munger, Phelps et al. 1989). Overexpression of HPV-E7 in HeLa cells enhanced Kv10.1 expression (Figure $13 \mathrm{~A})$, suggesting again transcriptional control of Kv10.1 by E2F1.

The disruption of Rb/E2F1 interaction by HPV-E7 occurs through Rb cleavage at the $\mathrm{C}$ terminus, induced by binding of HPV-E7 to $\mathrm{Rb}$ and recruitment of the protease calpain. Proteolysis of Rb releases active E2F1 (Darnell, Schroder et al. 2007). To test whether the HPV-E7 effect on Kv10.1 expression occurs through E2F1 release after $\mathrm{Rb} / \mathrm{E} 2 \mathrm{~F} 1$ disruption, the action of endogenous HPV-E7 oncoprotein in HeLa cells was interfered by treatment with the calpain inhibitor PD150606. Kv10.1 expression was subsequently measured at both the mRNA and protein levels. Transcriptional levels were determined by qRT-PCR (Figure $13 \mathrm{C}$ ), using the transferrin receptor as a reference mRNA. After calpain inhibitor treatment, relative Kv10.1 mRNA levels were significantly down regulated compared to untreated or DMSO treated cells (oneway ANOVA; $P=0.0009$ ). E2F1 mRNA levels (Figure 13 D) also revealed a 
significant decrease after calpain inhibitor treatment (one-way ANOVA, $P=0.0005$ ). Such a decrease can be interpreted as a reduction of the auto regulatory control of E2F1 transcription that occurs physiologically before G1/S transition, when Rb/E2F1 complex has not been yet disrupted (Johnson, Ohtani et al. 1994). Expression of endogenous Kv10.1 protein after calpain inhibition was also determined by immunoprecipitation followed by Western blot. Kv10.1 was also down regulated at the protein level after calpain inhibitor treatment (Figure 13 B). Altogether, these results indicate that $\mathrm{Rb} / \mathrm{E} 2 \mathrm{~F} 1$ represses $\mathrm{Kv} 10.1$ transcriptional activity, and disruption of the Rb/E2F1 complex by HPV-E7 leads to transcriptional activation of Kv10.1 through E2F1. This prompted the study on the impact that E2F1 transcription factor might play in Kv10.1 expression kinetics during the cell cycle. 
A. Kv10.1 protein upregulation by HPV-E7 and E2F1 overexpression

+HPV-E7 +E2F1 Control

Kv10.1

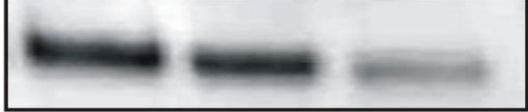

C. Kv10.1 relative mRNA expression

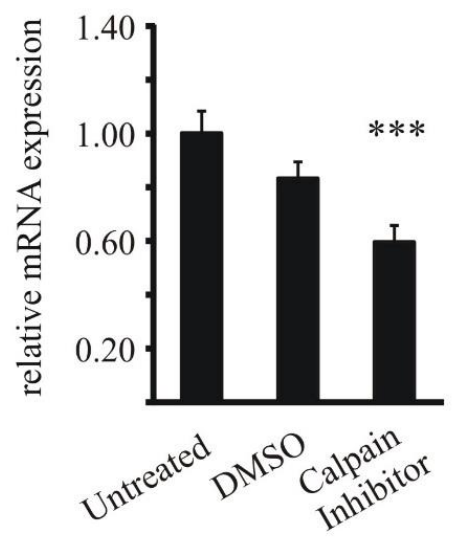

B. Kv10.1 protein downregulation by Calpain Inhibitor Pd150606 treatment

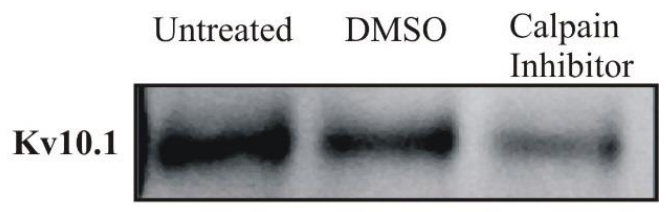

D. E2F1 relative mRNA expression

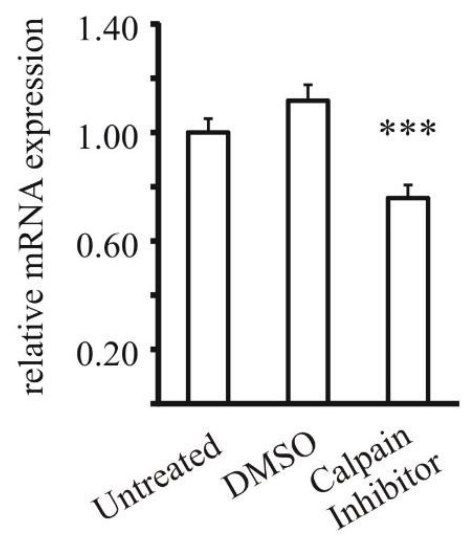

Figure 13. Kv10.1 expression is regulated by the pRB/E2F1 pathway in HeLa cells. (A) Kv10.1 expression was up regulated after E2F1 and HPV-E7 overexpression (B) Kv10.1 expression was down regulated after calpain inhibitor treatment. (C) Relative mRNA Kv10.1 levels were significantly downregulated compared to untreated and DMSO treated cells (one-way ANOVA; $P=0.0009$ ). (D) Relative mRNA E2F1 levels were also significantly downregulated compared to untreated and DMSO treated cells (one-way ANOVA; $P=0.0005$ ).

\subsection{Requirement of an E2F1 responsive element for the control of Kv10.1 promoter}

In order to understand the mechanisms underlying the cell cycle dependent expression of $\mathrm{Kv} 10.1$, the minimal promoter $(\mathrm{KCNH} 1 p r)$ containing an E2F1 responsive element 
(Figure 14 A) was cloned into the pGL3 luciferase reporter vector. Then, promoter activity was measured by luciferase assay. HeLa cells were synchronized, released and transfected in 4-hour intervals with the reporter plasmids encoding firefly luciferase driven by $\mathrm{KCNHIpr}$, and Renilla luciferase driven by the CMV promoter as an internal control. Firefly luciferase activity was normalized using Renilla luciferase to account for differences in the number of cells and/or transfection efficiency.

Firefly luciferase activity under the control of the $\mathrm{KCNH} 1 \mathrm{pr}$ varied significantly with time (One Way ANOVA, $P<0.0001$ ) and followed the same cyclic pattern as endogenous protein levels (Figure 14 and Figure 12). As the cells passed through $\mathrm{G} 1 / \mathrm{S}$ border $(0 \mathrm{~h})$ and progressed through $\mathrm{S}$ phase $(4 \mathrm{~h}), \mathrm{KCNH} 1 \mathrm{pr}$ activity increased and reached a peak when the cells were at the G2/M transition ( $8 \mathrm{~h}$ ). Then, activity levels declined gradually as the cells completed mitosis (12 h) and progressed through G1 phase (16 h and $20 \mathrm{~h}$ ). Then, the luciferase activity increased again when the cells were entering S phase (24 h).

To address whether Rb/E2F1 pathway controls KCNH1pr transcription activity, HPVE7 oncoprotein was overexpressed in HeLa cells and $K C N H 1$ promoter activity was assessed (Figure 14 B). HPV-E7 overexpression significantly increased luciferase activity driven by $K C N H 1 p r$ containing the E2F1 responsive element (Two-way ANOVA. Hours after release $P=0.0045$, HPV-E7 overexpression $P<0.0001$ ). 
A.

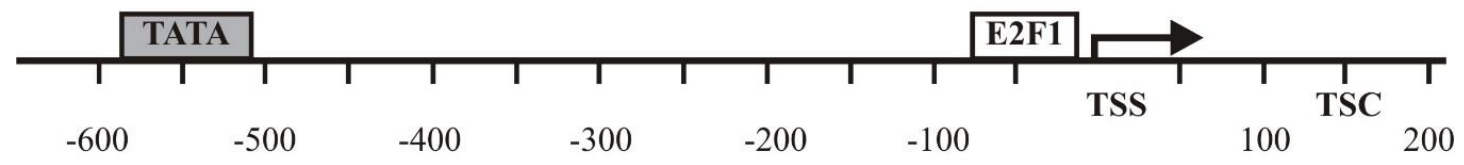

B. $\quad \mathrm{KCNH} 1$ promoter activity along the cell cycle

C.

E2F1 element favors $\mathrm{KCNH} 1$ promoter activity

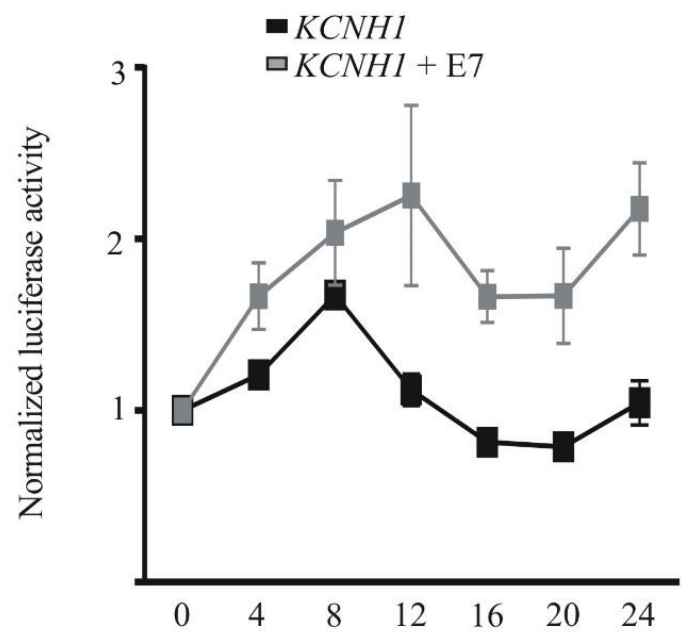

- KCNH1 + KCNH1-mut E2F1

ㅁ KCNH1- mut E2F1+ E7

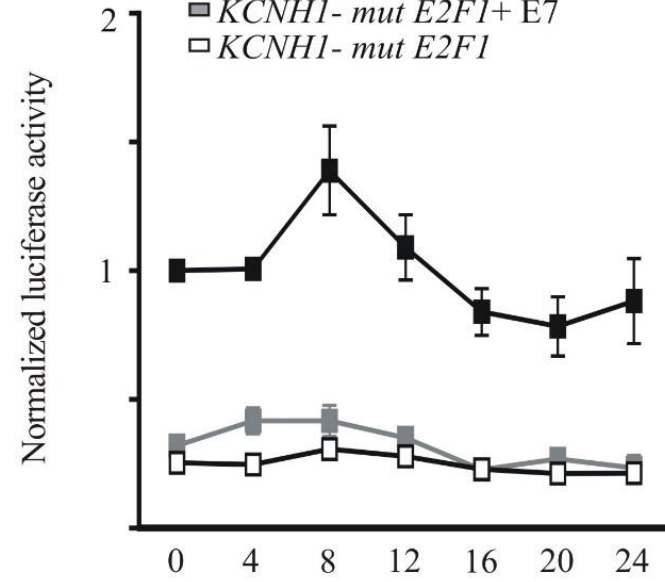

Hours after thymidine release

Hours after thymidine release

Figure 14. E2F1 responsive element controls KCNH1 activity. (A) Schematic of human KCNH1 promoter indicating E2F1 responsive element upstream the transcription starting site (TSS). (B) Luciferase activity driven by $\mathrm{KCNH} 1$ promoter showed a peak activity during G2/M transition (One-Way ANOVA, $P<0.0001$ ). HPVE7 overexpression increased $\mathrm{KCNH} 1$ promoter activity (Two-way ANOVA. Hours after release $P=0.0045$, HPV-E7 overexpression $P<0.0001)$. (C) E2F1 responsive element is necessary for $\mathrm{KCNH} 1$ gene expression. Mutation on E2F1 responsive element (KCNH1-mutE2F1) abolished promoter activity. HPV-E7 overexpression did not have any effect in the presence of KCNH1-mutE2F1, indicating that HPV-E7 enhances $\mathrm{KCNH} 1$ through the release of $\mathrm{E} 2 \mathrm{~F} 1$ from $\mathrm{Rb}$ repression (Two-way ANOVA. Hours after release $P<0.0001$, mutated $K C N H 1 P<0.0001)$. 
Both the basal activity of KCNH1pr and the effect of HPV-E7 depended on E2F1. When the E2F1 binding sequence was removed by mutagenesis (KCNH1pr-mutE2F1, Figure 14 A), luciferase activity driven by the mutant promoter was significantly reduced compared to the wild type $K C N H 1 p r$ (Figure $14 \mathbf{C}$ ), both in the absence and after over expression of HPV-E7. (Two-way ANOVA. Hours after release $P<0.0001$, mutated $K C N H 1 P<0.0001$ ), indicating that enhanced $K C N H 1$ promoter activity after HPV-E7 overexpression was due to E2F1 release from Rb repression, and subsequent E2F1 binding to the promoter.

\subsection{Interaction of E2F1 with Kv10.1 promoter}

According to the above results, maximum Kv10.1 promoter activity is restricted to $\mathrm{G} 2 / \mathrm{M}$ border, and both promoter activity and protein expression are regulated by $\mathrm{Rb} / \mathrm{E} 2 \mathrm{~F} 1$ pathway. However, the peak activities of E2F1 and $\mathrm{KCNH} 1 \mathrm{pr}$ are shifted by several hours (Figure 12). This could indicate that $K C N H 1$ promoter activation through E2F1 is a secondary effect of E2F1 activity at G1/S border, where E2F1 induces the activation of genes that later could enhance Kv10.1 transcription. Alternatively, it can be explained by a delay in activation of the promoter after E2F1 activity increase, as it has been documented for other genes (Takahashi, Rayman et al. 2000, Zhu, Giangrande et al. 2004). Experiments with KCNH1-mutE2F1 point to a direct interaction, but we decided to test for physical interaction between E2F1 and the $K C N H 1$ promoter using ChIP.

ChIP assays were performed in synchronized HeLa cells using anti-E2F1 antibody, and qRT-PCR was used to amplify the endogenous $K C N H 1$ promoter region containing the E2F1 binding site (Figure 15 A). Endogenous CCNA2 (Cyclin A2) 
promoter region containing the E2F1 binding site was used as positive control (Figure 15 B). Cyclin A2 has been reported as an E2F1 target gene regulated at the G2/M border (Takahashi et al, 2000; Zhu et al, 2004).

Using a transcription factor whose activity is time-dependent, ChIP assays require synchronization of the cells in order to increase the probability of the transcription factor being bound to its acceptor site. As shown in Figure 15, E2F1 was found to interact with $\mathrm{KCNH} 1$ and $C C N A 2$ promoters. As the cells passed through G1/S border and $\mathrm{S}$ ( $0 \mathrm{~h}$ and $4 \mathrm{~h}$ respectively), weaker binding of E2F1 to $\mathrm{KCNH} 1$ and $C C N A 2$ promoters was observed. Interestingly, when the cells were at the G2/M transition, the interaction between $\mathrm{E} 2 \mathrm{~F} 1$ and $\mathrm{KCNH} 1$ promoter was significantly increased (OneWay ANOVA, $P<0.0001)$. As expected, the interaction between E2F1 and CCNA2 promoter was also significantly increased (One-Way ANOVA, $P=0.0001$ ). As soon as mitosis was completed and the cells re-entered the cell cycle (12 h), E2F1 binding to either $\mathrm{KCNH} 1$ or $C \mathrm{CNA} 2$ promoters was dramatically diminished.

A second, albeit weaker peak of E2F1 binding was detected at later time points on both $K C N H 1$ promoter $(20 \mathrm{~h})$ and $C C N A 2$ promoter $(16$ and $20 \mathrm{~h})$. This can arise from the possibility that residual binding comes from remaining G2/M cells (Figure 11), or because E2F1 binding between $16 \mathrm{~h}$ and $20 \mathrm{~h}$ responds to the large expression levels of E2F1 at those time points (Figure 12).

As expected, Cyclin A2 protein expression was markedly up-regulated during the G2/M transition ( $8 \mathrm{~h}$ ) in synchronized HeLa cells (Figure 16). In contrast, Kv10.1 mRNA levels were significantly increased after the completion of mitosis at $12 \mathrm{~h}$ (One-Way ANOVA, $P<0.0001$ ). Kv10.1 protein expression was also markedly upregulated between $\mathrm{G} 2 / \mathrm{M}$ transition $(8 \mathrm{~h})$ and completion of mitosis (12 h). Suggesting 
that Cyclin A2 and Kv10.1 transcription are both regulated during G2/M border, a time when E2F1 is bound to the promoters despite the low overall amount of E2F1 transcription factor. Nevertheless, Kv10.1 kinetics seems to be different compared to Cyclin A2 (Figure 16D).

A. E2F1 binding to $\mathrm{KCNH} 1$ promoter

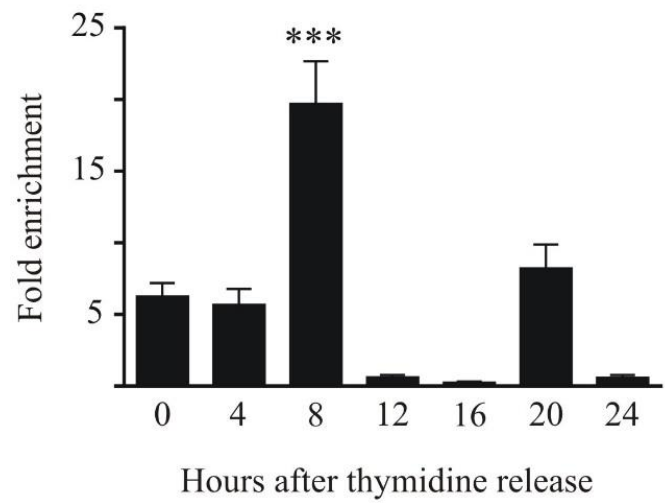

B. E2F1 binding to Cyclin A2 promoter

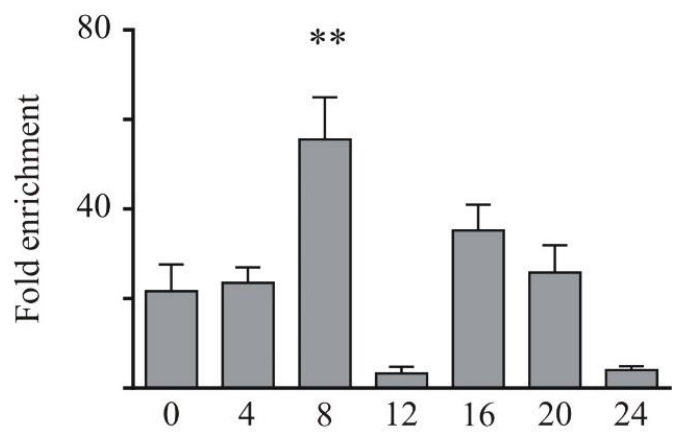

Hours after thymidine release

Figure 15. E2F1 binding during the cell cycle progression. (A) E2F1 binding to endogenous $\mathrm{KCNH}$ 1 promoter during $\mathrm{G} 2 / \mathrm{M}$ transition $(8 \mathrm{~h})$. One-Way ANOVA, $P<0.0001$ (B) E2F1 binding to endogenous CCNA2 promoter (Cyclin A2) during G2/M transition ( $8 \mathrm{~h}$ ). One-Way ANOVA, $P=0.0001$. Immunoprecipitated chromatin was analyzed by qRT-PCR using primers in the $K C N H 1$ and Cyclin A2 promoters. Cyclin A2, an E2F1 target gene regulated at the G2/M transition was used here as a positive control. Fold enrichment was calculated relative to GAPDH promoter signal. GAPDH is a non-E2F1 regulated gene. 
A.

E2F1 mRNA levels along the cell cycle

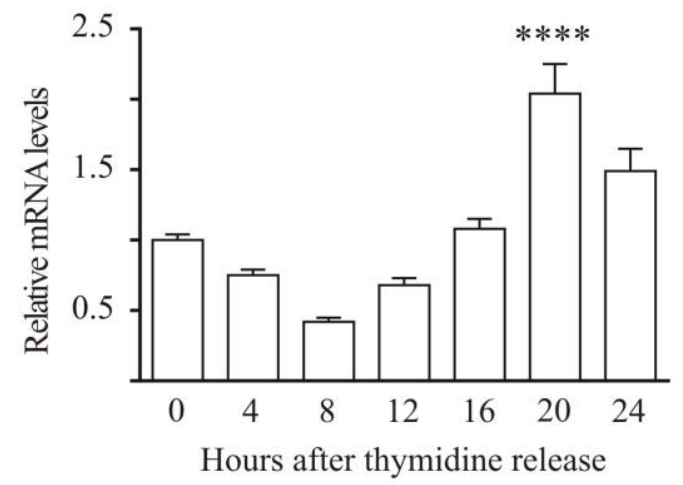

C. Kv10.1 and Cyclin A2 expression in synchronized HeLa cells

$\mathrm{Kv} 10.1$

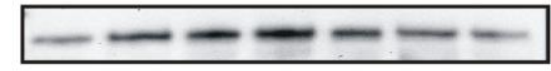

Cyclin A2

Calnexin

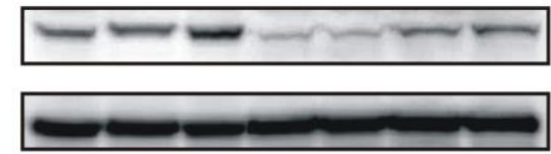

$\begin{array}{lllllll}0 & 4 & 8 & 12 & 16 & 20 & 24\end{array}$ Hours after thymidine release
B. Kv10.1 mRNA levels along the cell cycle

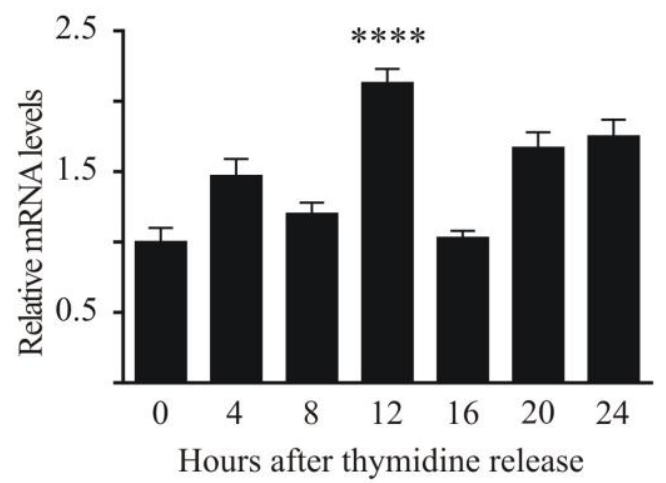

\section{Kv10.1 and Cyclin A2 Western blot densitometry}

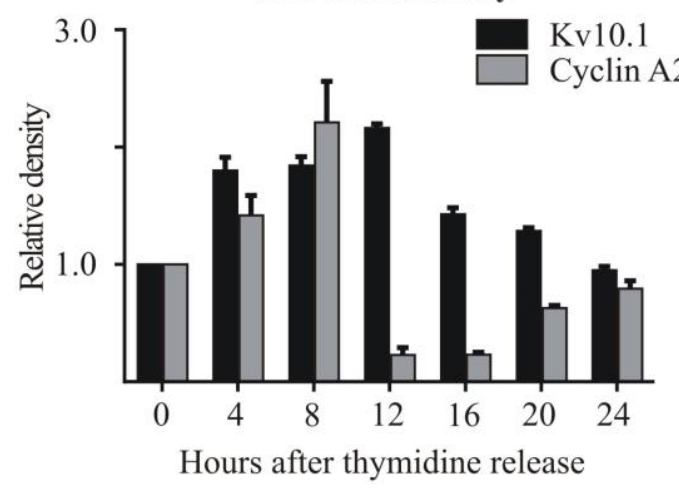

Figure 16. Analysis of gene expression during the cell cycle in HeLa cells. (A) E2F1 mRNA levels during cell cycle progression. E2F1 mRNA levels increased as the cells were at the G1/S border and progress through S phase. One-Way ANOVA, $P<0.0001$ (B) In contrast, Kv10.1 mRNA levels increased markedly after the completion of mitosis (12 h). One-Way ANOVA, $P<0.0001$ (C and D) Western blot and densitometry analysis of Kv10.1 and Cyclin A2 protein expression during the cell cycle. Kv10.1 reached the peak expression between $8 \mathrm{~h}$ and $12 \mathrm{~h}$ after thymidine release, when the cells completed mitosis. Cyclin A2 reached the peak expression at the G2/M border, then it was dramatically down regulated. Expression of Calnexin was assessed as loading control. 


\subsection{Kv10.1 knockdown delays the G2/M transition of HeLa cells}

We have shown that Kv10.1 protein expression is enriched in G2 and mitosis. The promoter activity is induced during G2/M transition, through the direct binding of E2F1 transcription factor. These results suggest that Kv10.1 is a candidate effector for cell cycle progression once the G1/S checkpoint control is satisfied. Thus, we decided to explore the role of Kv10.1 in cell cycle progression by knocking down the expression through RNA interference. Specific siRNA against Kv10.1 was transfected into HeLa cells, and the knockdown efficiency was determined using qRT-PCR (Figure 17C). After siRNA treatment, the relative Kv10.1 mRNA levels significantly dropped compared to siRNA control (One-Way ANOVA, $P=0.0012$ ).

Cell cycle profile was determined in asynchronous population of growing HeLa cells, transfected with specific siRNA against Kv10.1 or control siRNA. FACS analysis using propidium iodide (PI) as a DNA stain was performed to evaluate the DNA content (Figure 17A). siRNA against Kv10.1 induced a significant increase of the cell fraction corresponding to $\mathrm{G} 2 / \mathrm{M}$ compared to siRNA control (t-test, $P=0.0152$ ), while the cell fraction corresponding to $\mathrm{G} 1$ (t-test, $P=0.1136$ ) and $\mathrm{S}(\mathrm{t}-\mathrm{test}, P=0.2275)$, remained in the same proportion compared to the controls (Figure 17 B).

An increase of the fraction of cells in a particular phase indicates that cells spend a longer time in that phase. Thus, the G2/M arrest of HeLa cells suggests that Kv10.1 expression is involved in the entry or progression through mitosis. 


\title{
A. FACS analysis of HeLa cells treated with siRNAs
}
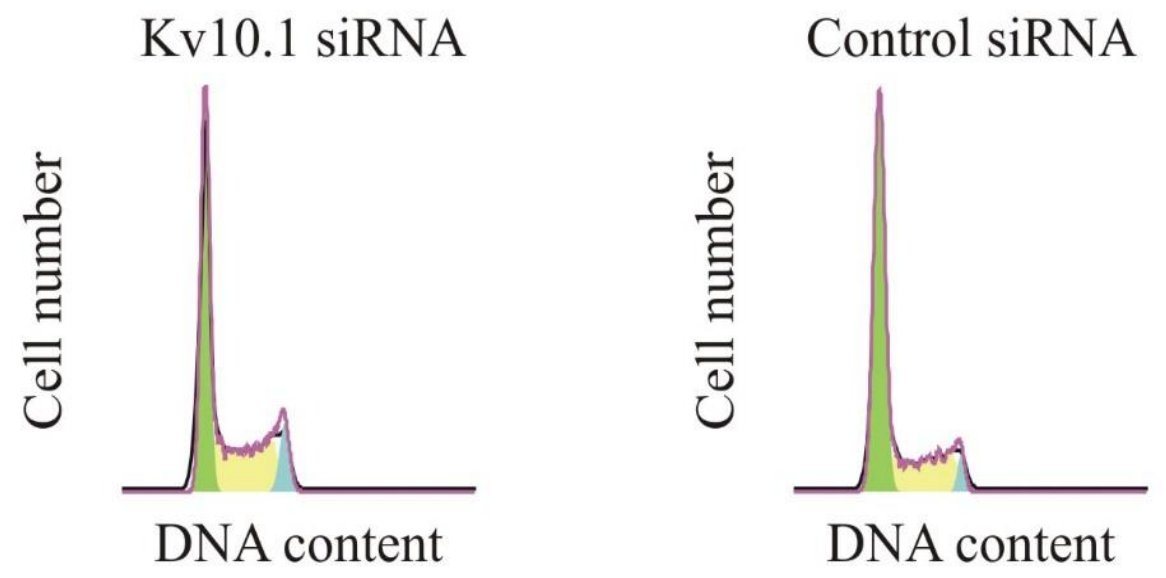

\section{B. Cell cycle distribution following Kv10.1 knockdown}

\author{
C. Kv10.1 knockdown
}
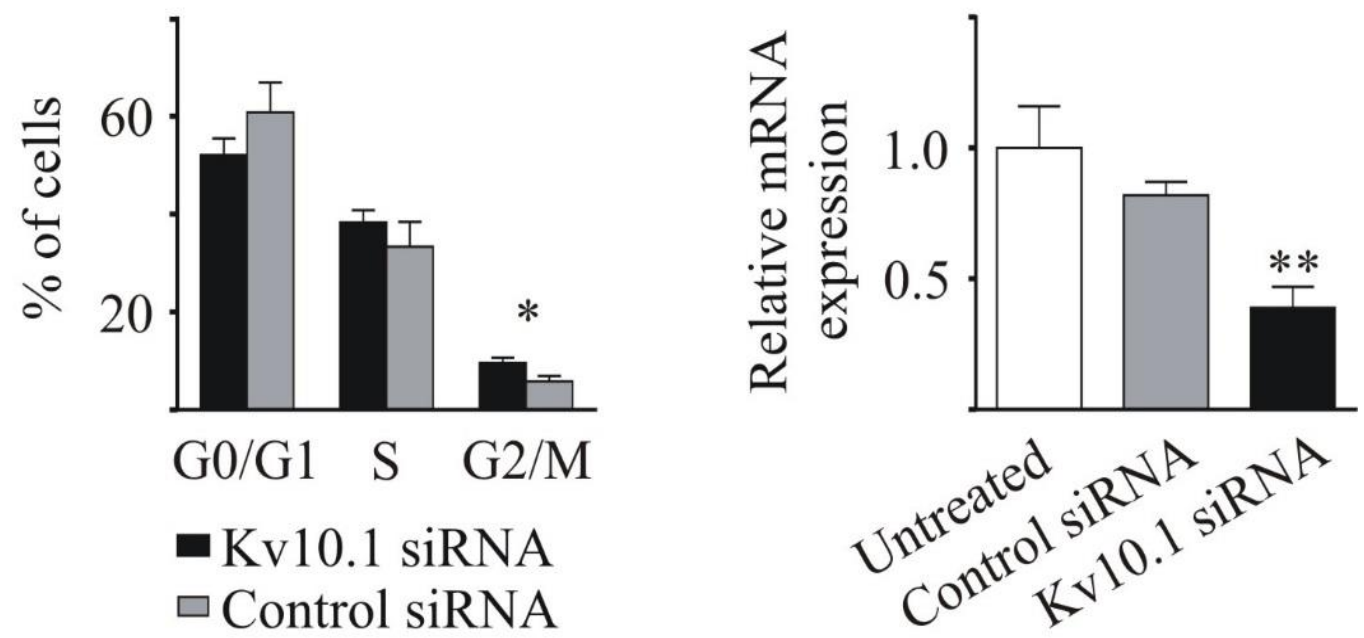

Figure 17. Kv10.1 knockdown induced G2/M arrest in HeLa cells. (A) Cells were transfected with control siRNA or Kv10.1 siRNA. After 48h cells were stained using propidium iodide (PI) for FACS analysis. (B) Kv10.1 siRNA significantly induced $\mathrm{G} 2 / \mathrm{M}$ arrest in HeLa cells (t-test, $P=0.0152$ ). The cell fraction corresponding to G1 (t-test, $P=0.1136$ ) and $\mathrm{S}(\mathrm{t}$-test, $P=0.2275)$ remained in the same proportion compared to siRNA control. (C) Knockdown efficiency was determined using qRT-PCR (OneWay ANOVA, $P=0.0012$ ). 


\subsection{Kv10.1 expression in normal non-neural tissue}

Previous studies indicated that Kv10.1 expression is enriched in human brain, but is not detectable in non-neuronal tissue (Pardo, del Camino et al. 1999). However, positive signal has been reported in restricted cell populations, which correspond to terminal developmental stages of different cell lineages (Hemmerlein, Weseloh et al. 2006). We have found that Kv10.1 expression is temporally correlated with the kinetics of cyclins A2 and B1 (Figure 10 and Figure 17). Both cyclins, as well as Kv10.1, are E2F1-regulated genes and are expressed at the G2/M border and during mitosis (Pines and Hunter 1991, Pines and Hunter 1994, Takahashi, Rayman et al. 2000, Zhu, Giangrande et al. 2004). We therefore hypothesized that Kv10.1 could be expressed in all cell types at a particular time window. If this window would represent a small fraction of the duration of the cell cycle, determination of the expression in the whole tissue would be frequently negative. In fact, cell cycle regulation of Kv10.1 expression was first reported during myoblast fusion. Kv10.1 expression has been linked with the hyperpolarization of the resting potential necessary for myoblast differentiation (Bijlenga, Occhiodoro et al. 1998).

We therefore set out to test whether Kv10.1 expression could be found in non-neuronal tissues during G2/M transition. To this end, immunohistochemistry was performed in normal tissue characterized by on-going proliferation. Intestinal epithelium contains continuous proliferating and differentiation programs. Stem cells located in the crypts undergo several rounds of amplification, giving rise to a proliferating progenitor cell population. Later, differentiation programs are activated and post mitotic cells undergo migration from the crypt to the tips of the adjacent villi or surface epithelium (Kosinski, Li et al. 2007, Humphries and Wright 2008, Shaker and Rubin 2010). Thus, 
human intestine provides an excellent model to study Kv10.1 expression during the course of G2 and mitosis (Figure 18).

Sections from paraffin-embedded normal colon were immunostained against Kv10.1 and Cyclin B1. As expected, Cyclin B1 immunostaining was localized to the bottom and sides of the crypt, where the proliferative compartment is found (Figure 18 and Figure 19). Kv10.1 immunostaining followed the same pattern as Cyclin B1. Kv10.1 positive cells found in the proliferative compartment of the colon crypt were also Cyclin B1 positive (Figure 20), indicating that Kv10.1 expression is enriched during $\mathrm{G} 2 / \mathrm{M}$ progression.

\section{Colonic crypt organization}

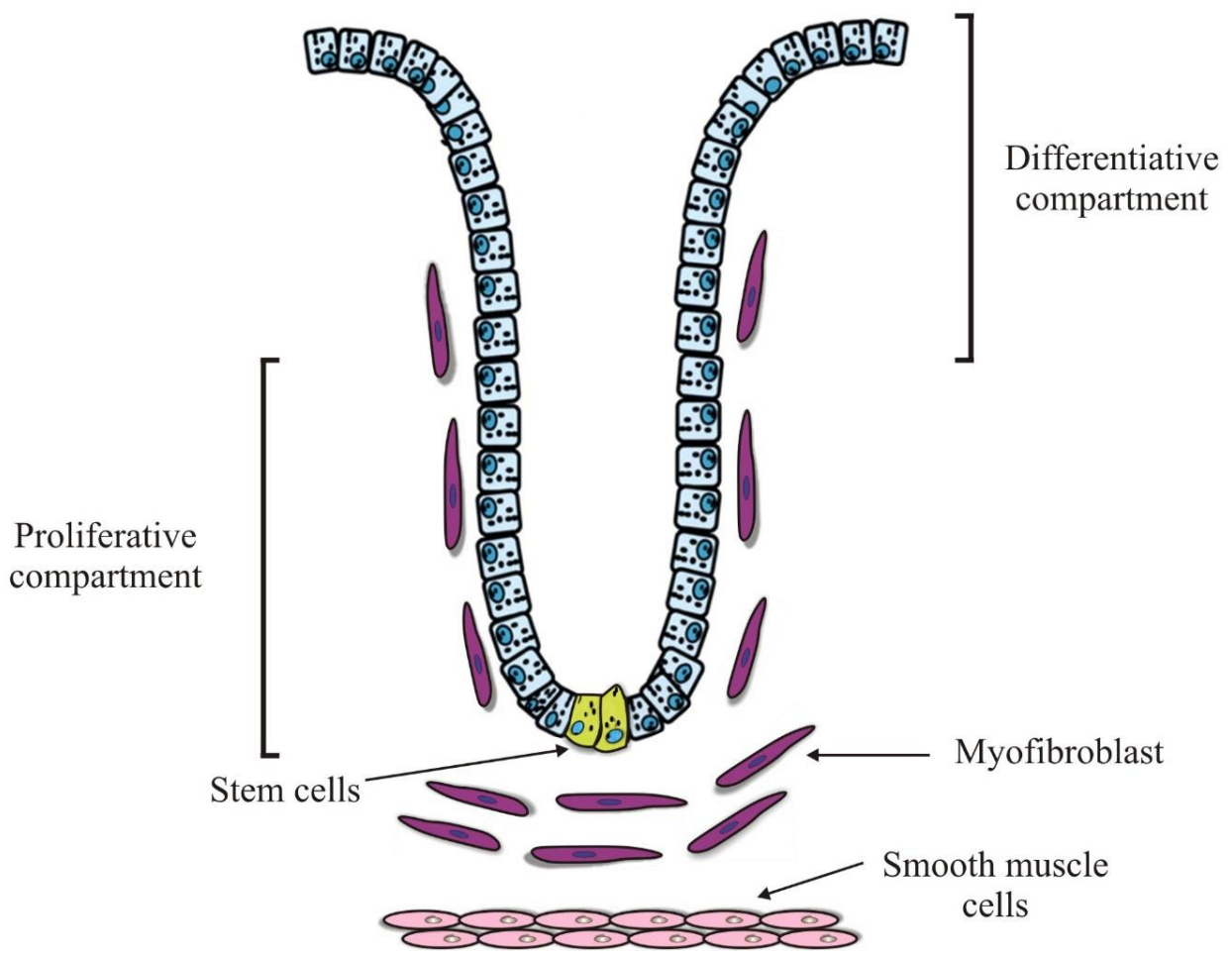

Figure 18. Illustration of the crypt axis. Stem cells are located at the bottom of the crypt, they give rise to progenitor cells which are located in the proliferative compartment. Afterwards, cells differentiate and migrate to the surface epithelium (Kosinski, Li et al. 2007). 


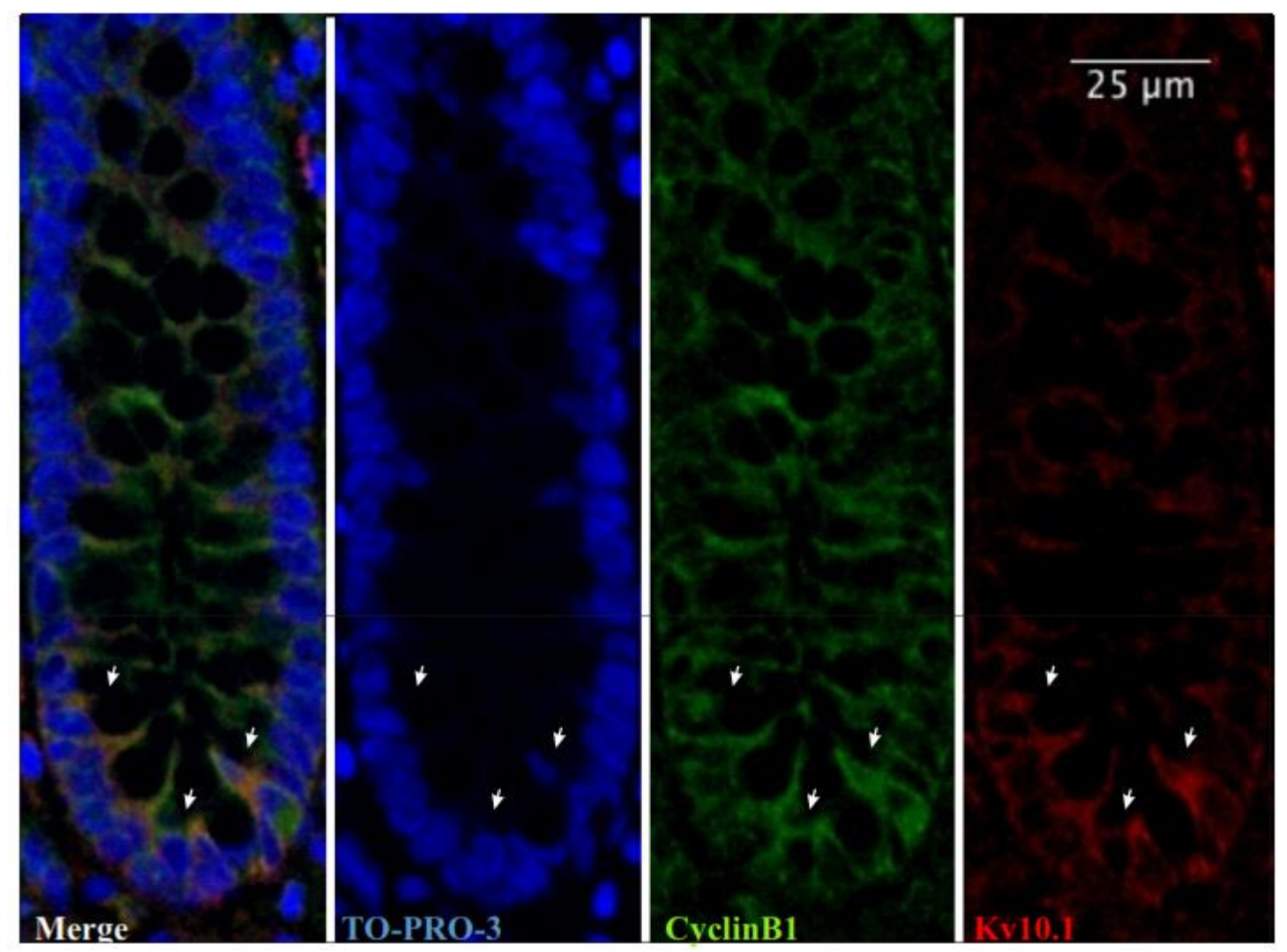

Figure 19. Immunohistochemistry of paraffin colon section. Cyclin B1 positive cells were localized to the proliferative compartment, at the bottom and sides of the crypt. Kv10.1 positive cells were also found in the proliferative compartment of the colon crypt. White arrows indicate Kv10.1 and Cyclin B1 enriched populations. Scale bar $25 \mu \mathrm{m}$. 


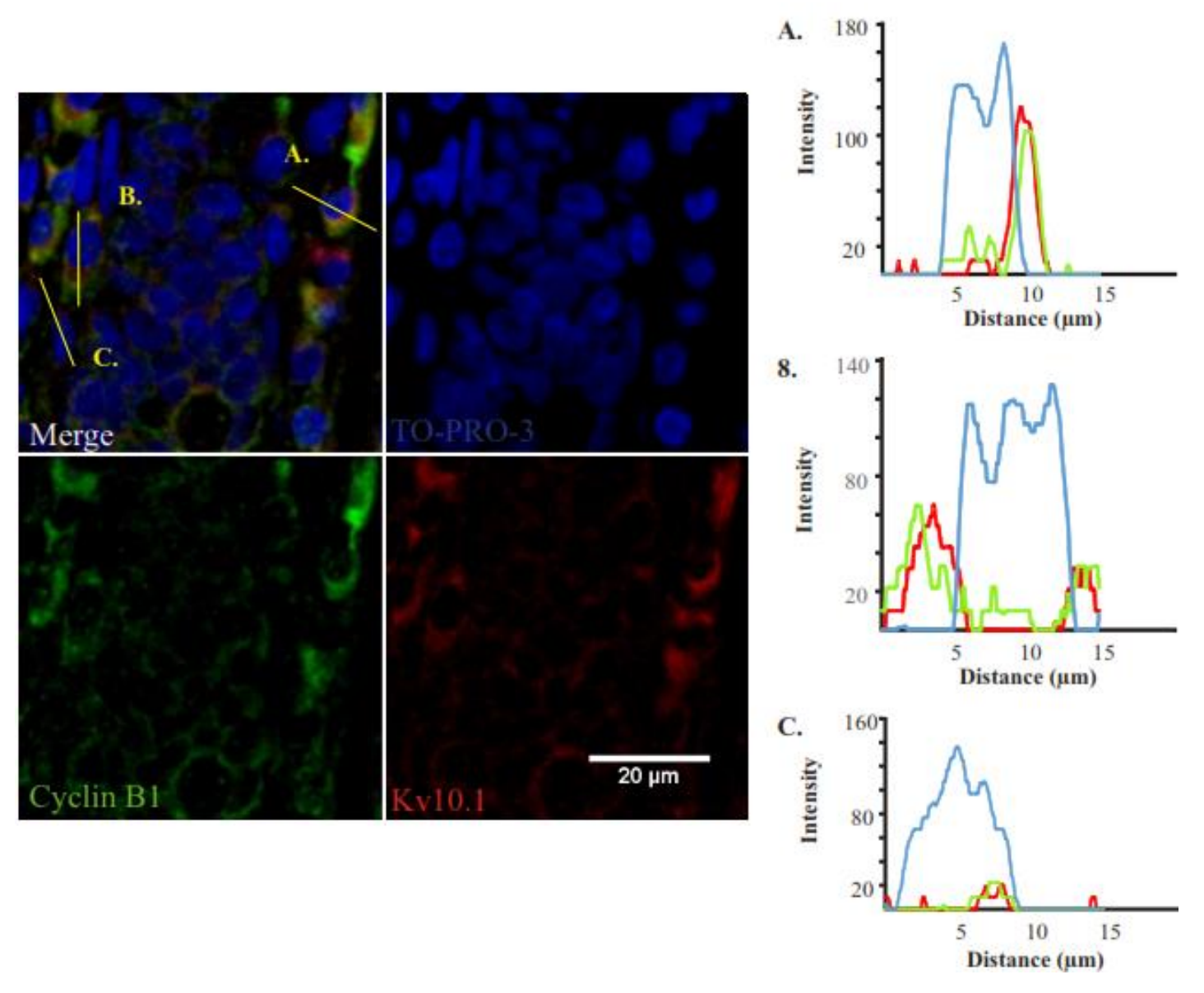

Figure 20. Kv10.1 enriched cells undergo G2/M progression in the proliferative compartment. Cyclin B1 immunostaining was used to determine cells undergoing G2/M progression. Scale bar $20 \mu \mathrm{m}$. 


\section{DISCUSSION}

In this study, we report that Kv10.1 is expressed in a defined time window during $\mathrm{G} 2 / \mathrm{M}$. This expression kinetics is regulated by the $\mathrm{Rb} / \mathrm{E} 2 \mathrm{~F} 1$ pathway. $\mathrm{Rb} / \mathrm{E} 2 \mathrm{~F} 1$ complex represses Kv10.1 transcriptional activity, and the disruption of the $\mathrm{Rb} / \mathrm{E} 2 \mathrm{~F} 1$ complex by HPV-E7 leads to release of E2F1 transcription factor, which directly binds to $K v 10.1 p r$ to activate transcription. Furthermore, we show that in asynchronous HeLa cells Kv10.1 knockdown increases the G2/M fraction, suggesting that in the absence of Kv10.1, cells spend on average more time in G2/M. Finally, by taking into account the Kv10.1 expression kinetics (its short time-window of expression), we found Kv10.1 expression in normal non-neuronal tissue. Proliferating population of cells located at the bottom and sides of colonic crypts show positive Kv10.1 signal. The small fraction of proliferating cells passing through G2/M are also positive for Kv10.1. These findings are crucial to mechanistically find an explanation of the influence of Kv10.1 on tumor cell proliferation and its aberrant expression in tumors.

\section{1 $\mathrm{Rb} / \mathrm{E} 2 \mathrm{~F} 1$ transcriptional control}

We identify that the Rb/E2F1 pathway, which appears to be disrupted in almost all cancer cells (Sherr and McCormick 2002), is directly involved in Kv10.1 transcription. Our data show that the disruption of the Rb/E2F1 complex by HPV-E7 overexpression results in increased free E2F1 levels, which, in turn, increase Kv10.1 promoter activity and protein expression. In contrast, when the $\mathrm{Rb} / \mathrm{E} 2 \mathrm{~F} 1$ repressor complex is maintained by preventing Rb degradation, both E2F1 and Kv10.1 expression are down regulated. 
$\mathrm{Rb}$ tumor suppressor activity resides mainly in its ability to restrict cell cycle progression. $\mathrm{Rb}$ actively represses gene expression by binding to $\mathrm{E} 2 \mathrm{~F} 1$ transcription factor, and recruiting HDAC (Harbour and Dean 2000, Rayman, Takahashi et al. 2002, Takaki, Fukasawa et al. 2004). Rb mutations, or loss of function due to deregulation of its upstream regulators, such as cyclin inhibitors and cyclin-cdk complexes, have been associated with lung (Xue, Sano et al. 2001, Coe, Thu et al. 2013), pancreatic (Mettus and Rane 2003, Carriere, Gore et al. 2011), and breast cancer (Ertel, Dean et al. 2010, Witkiewicz, Cox et al. 2013), as well as glioblastoma multiforme (Cen, Carlson et al. 2012). Interestingly, Kv10.1 expression has also been reported in an overlapping broad range of tumors (Hemmerlein, Weseloh et al. 2006). Our results suggest that frequent Kv10.1 aberrant expression might be explained by loss of $\mathrm{Rb}$ repression.

Upon growth-factor stimulation, signaling cascades are activated to target Cyclin DCdk4/6 and Cyclin E-Cdk2 complexes, which promote Rb hyperphosphorylation and the subsequent E2F1 release. Since E2F1 activates E2F1-responsive promoters of genes that encode DNA replication proteins, and also proteins required for G2 progression and mitosis, e.g. cyclin $\mathrm{B}$, the $\mathrm{Rb} / \mathrm{E} 2 \mathrm{~F} 1$ pathway appears as a link between growth signals and the cell cycle gene expression (Wong, Dong et al. 2011). Our results show that upon $\mathrm{Rb} / \mathrm{E} 2 \mathrm{~F} 1$ complex disruption, E2F1 binds directly to $\mathrm{Kv} 10.1 \mathrm{pr}$ to enhance gene expression. Previous studies in MCF-7 breast cancer cell line have indeed associated the mitogenic factor IGF-I signaling with enhanced Kv10.1 expression (Borowiec, Hague et al. 2007). IGF-1 signaling cascade is transduced by phosphatidylinositol-3 kinase (PI3K) and Akt protein kinase, known for targeting substrates that prompt cell cycle progression (Dufourny, Alblas et al. 1997, Vanhaesebroeck and Alessi 2000, Dupont and Le Roith 2001). Cell cycle reentry after 
IGF-I stimulation results in increased Cyclin D-Cdk4/6 and Cyclin E-Cdk2 activity, which promote $\mathrm{Rb}$ phosphorylation and therefore cell cycle progression. This would mean that enhanced Kv10.1 expression seen after IGF-I stimulation happens as a result of $\mathrm{Rb} / \mathrm{E} 2 \mathrm{~F} 1$ complex disruption, and transcriptional E2F1 activity. Additionally, Kv10.1 would appear as a downstream effector of growth signals and G1/S check point pathways. Compatible with this idea, Kv10.1 blockage has been shown to abrogate the effect of IGF-I on cell cycle progression (Borowiec, Hague et al. 2007, Borowiec, Hague et al. 2011).

In addition to cyclin-cdks mediated phosphorylation, p38 MAP kinase phosphorylation on $\mathrm{Rb}$ also prevents its association with both HDACs and E2F1, to enable gene expression of E2F1 target genes. The p38 MAPK pathway is mostly activated in response to cellular stress, but it can also be activated by mitogenic stimulation (Faust, Schmitt et al. 2012). In the MG-63 osteosarcoma cell line, p38 MAPK inhibition induces Kv10.1 down regulation and slows down proliferation ( $\mathrm{Wu}$, Zhong et al. 2013). The HDAC inhibitor SAHA (suberoylanilide hydroxamic acid) has been shown to increase Kv10.1 in HNSCC- derived cell lines. This up regulation is also associated with acetylation on histones H3 and H4K16 (Menendez, Villaronga et al. 2012). These observations together with our findings point towards $\mathrm{Rb}$ as a key repressor of Kv10.1 expression. Thus, Rb repression on Kv10.1 might depend on binding to E2F1 transcription factor, to repress its transcriptional activity, and HDAC recruitment so the chromatin is less accessible to the transcriptional machinery. Compatible with the negative regulation of Kv10.1 by Rb, previous observations have shown that Rb is frequently inactivated by HPV-E7 expression in cervical cancer and other squamous cell carcinomas (Moody and Laimins 2010, Andersen, Koldjaer Solling et al. 2013). Consequently, Kv10.1 expression has also been detected in 
cervical cancer biopsies, as well as in head and neck squamous cell carcinoma (HNSCC) (Farias, Ocana et al. 2004, Menendez, Villaronga et al. 2012). Further evidence has been reported in primary keratinocytes, which express Kv10.1 only after being immortalized by HPV-E7 (Diaz, Ceja-Ochoa et al. 2009).

Some models suggest that deregulation of E2F1 due to loss of $\mathrm{Rb}$ is a critical event during tumor formation. For example, Rb-deficient mice have been shown to develop pituitary tumors (Jacks, Fazeli et al. 1992), but have a reduced frequency of pituitary tumor formation when crossed with $\mathrm{E} 2 \mathrm{~F} 1^{-/-}$mice (Yamasaki, Bronson et al. 1998). Increased E2F1 levels, due to aberrant Rb function, are commonly found in lung, breast, and pancreatic cancers (Eymin, Gazzeri et al. 2001, Gorgoulis, Zacharatos et al. 2002, Han, Park et al. 2003, Yamazaki, Yajima et al. 2003). Amplification of the E2F1 gene has also been observed in esophageal, colorectal cancer and leukemia cell lines (Saito, Helin et al. 1995, Suzuki, Yasui et al. 1999). Remarkably, Kv10.1 expression is also reported in these E2F1-positive tumor types, and is correlated with poor prognosis for patients of gastric (Ding, Luo et al. 2007), and colon cancer (Ousingsawat, Spitzner et al. 2007), as well as leukemias (Agarwal, Griesinger et al. 2010).

It is believed that E2F1 oncogenic potential comes from its ability to stimulate proliferation, owing to transcriptional activation of genes involved in cell cycle progression. However, the scenario seems more complex, as E2F1 has also been reported as tumor suppressor (Pierce, Schneider-Broussard et al. 1999, Johnson and Degregori 2006). Loss of E2F1 reduces the incidence of pituitary tumors in $\mathrm{Rb}^{+/}$, and mice lacking E2F1 have a relative low incidence of tumors. Nevertheless, abnormalities are evident in $\mathrm{E} 2 \mathrm{~F}^{-/-}$mice with increasing age. These mice are predisposed to testicular atrophy, salivary gland dysplasia, and to develop lung 
adenocarcinoma, lymphomas and reproductive tract sarcomas (Yamasaki, Jacks et al. 1996, Yamasaki, Bronson et al. 1998). This paradox is thought to be context dependent, since E2F1 also activates genes important for apoptosis and senescence. E2F1 limits tumor development by transcriptional activation of ARF, which in turn induces p53 accumulation and the subsequent tumor suppression (Johnson and Degregori 2006, Russell, Weaks et al. 2006). Previous studies have suggested p53 regulation on Kv10.1. p53 induces miR34a activation, and miR34a binds directly to the 3'UTR of Kv10.1 promoter to suppress its expression (Lin, Li et al. 2011). In the context of our findings, these observations suggest that Kv10.1 expression is controlled upstream by E2F1 transcription factor, and that loss of regulatory pathways controlling cell cycle progression and tumor formation e.g. Rb and p53 would determine the oncogenic potential of E2F1 and Kv10.1.

\subsection{Kv10.1 expression towards G2/M}

We have found that Kv10.1 expression changes periodically during the cell cycle, rather than being constitutive. Kv10.1 mRNA and protein levels increase and reach a peak after mitosis and they decline gradually as cells reenter a new cycle. Furthermore, knockdown experiments reveal that Kv10.1 down regulation induces accumulation of cells towards $\mathrm{G} 2 / \mathrm{M}$, which indicates that cells take, on average, a longer time to complete mitosis.

Our results in HeLa cells show that Kv10.1 expression is temporally restricted to a short time window during G2/M. Such kinetics could explain the low expression levels detected in normal tissues outside the CNS, since end-differentiated normal tissues show low proliferation, and therefore very few cells in a given tissue would be at that 
point of the cell cycle. Nevertheless, we have found that proliferating cells outside the CNS express Kv10.1. Cells of human colon crypts undergo continuous proliferation and differentiation programs. Stem cells go through several rounds of amplification, giving rise to proliferating progenitor cell population located at the bottom of the crypt (Humphries and Wright 2008). We found a small percentage of cyclin B1-positive cells at the bottom of the crypt, and strikingly those cells were also positive for Kv10.1. This data suggests that in peripheral tissues, as well as somatic cancer cells, Kv10.1 is expressed in proliferating cells progressing through $\mathrm{G} 2 / \mathrm{M}$, when cyclin B1 expression starts increasing.

Recently, our group has reviewed the mechanism by which potassium channels are involved in cell cycle regulation (Urrego, Tomczak et al. 2014). In proliferating cells, changes in the transmembrane potential have been associated with cell cycle progression (Blackiston, McLaughlin et al. 2009). For example, the membrane potential of MCF-7 cells hyperpolarizes during G1/S and G2/M transitions (Wonderlin, Woodfork et al. 1995), whereas quiescent CHO cells enter the cell cycle after membrane depolarization (Cone 1971). $\mathrm{K}^{+}$channels control alterations in membrane permeability, and thus determine the resting potential along the cell cycle. Shifting the membrane potential towards the equilibrium for $\mathrm{K}^{+}$increases the driving force available for $\mathrm{Ca}^{2+}$ entry. $\mathrm{Ca}^{2+}$ functions as second messenger to elicit intracellular signals, implicated, among other crucial processes in cell physiology, in the control of proliferation. (Lee, Sayeed et al. 1993, Lin, Boltz et al. 1993, LeppleWienhues, Berweck et al. 1996, Lallet-Daher, Roudbaraki et al. 2009). Myoblasts fuse to form multinucleated skeletal muscle fibers, contributing to muscle growth (Rochlin, Yu et al. 2010). Expression of Kv10.1-mediated current has been associated with the initial hyperpolarization of the resting potential before myoblast fusion: the current 
density reaches a peak in fusion-competent myoblasts and then declines after fusion (Bijlenga, Occhiodoro et al. 1998, Occhiodoro, Bernheim et al. 1998). This would be compatible with Kv10.1 expression shortly before the membrane fusion, when myoblasts progress through mitosis to leave the cell cycle. Our results show that enriched Kv10.1 expression towards the beginning and the exit from mitosis is not an isolated event in differentiating myoblast, but can rather be extrapolated to other cell types.

Apart from changes in the expression level of Kv10.1 during G2/M, our group has reported that electrophysiological properties of Kv10.1 heterologously expressed in Xenopus oocytes also change during oocyte maturation. Xenopus oocytes are arrested in G2 phase for an indefinite period of time, and in response to the steroid hormone progesterone they are induced to complete the first meiotic division and develop into fertilizable eggs. Progesterone activates signaling cascades that target MPF (mitosis promoting factor, the catalytic subunit $\mathrm{p} 34^{\mathrm{cdc} 2}$ and its regulatory partner cyclin B). MPF is responsible for the control of G2/M transition during both meiotic and mitotic divisions. During progesterone-dependent maturation, the electrophysiological properties of Kv10.1 channels heterologously expressed in Xenopus oocytes are strongly modulated, owing to a voltage-dependent block by intracellular $\mathrm{Na}^{+}$that causes a reduction of Kv10.1-mediated current (Bruggemann, Stuhmer et al. 1997, Pardo, Bruggemann et al. 1998). The resulting net loss of $\mathrm{K}^{+}$conductance at the G2/M transition may be a way to achieve membrane depolarization associated with mitosis. Thus, Kv10.1 expression and permeation properties appear to be modulated by the cell cycle, suggesting that Kv10.1 channels are relevant targets of cell cycle regulatory pathways, a notion compatible with a contribution to cell cycle progression. 
Besides the permeation-dependent mechanisms controlling progression through the cell cycle, e.g., like in the case of myoblast fusion, Kv10.1 has also been reported to influence cell proliferation and tumorigenesis in the absence of $\mathrm{K}^{+}$permeation (Hegle, Marble et al. 2006, Downie, Sanchez et al. 2008). Recently, our group has described a permeation-independent mechanism relying on protein-protein interaction between the C-terminus of Kv10.1 and Rabaptin5 as well as cortactin (Herrmann, Ninkovic et al. 2012, Ninkovic, Mitkovski et al. 2012). Through these interaction partners, Kv10.1 is proposed to induce disassembly of the primary cilium (Sánchez, Urrego et al. 2014). The primary cilium behaves like an antenna to sense chemical and mechanical growth cues. G0 cells and cells progressing through G1 retain the primary cilium. It is assembled during cell cycle exit, and disassembled before the appearance of the mitotic spindle. The crosstalk between ciliary factors and regulators of the cell cycle influence cell cycle reentry (Pan, Seeger-Nukpezah et al. 2013). Moreover, it coordinates the activation and transduction of signaling pathways such as sonic hedgehog (SHH), important during development (Seeley and Nachury 2010). Our results indicate that Kv10.1 is expressed during G2/M, when it might contribute to disassembly of primary cilium. Thus, Kv10.1 role in tumorigenesis could be associated with destabilization of the primary cilium, which might result in faster ciliary resorption and faster cell cycle reentry.

\section{3 $\mathrm{Rb} / \mathrm{E} 2 \mathrm{~F} 1$ restricts $\mathrm{Kv} 10.1$ expression to the $\mathrm{G} 2 / \mathrm{M}$ border}

We have described a mechanism that might control Kv10.1 expression kinetics during G2/M. E2F1 transcription factor binds directly to Kv10.1 promoter to induce gene expression, when binding of E2F1 to Kv10.1 promoter was prevented by mutation on 
the E2F1-responsive element, Kv10.1 periodicity and promoter activity were abolished.

Nevertheless, the kinetics of expression of E2F1 and Kv10.1 do not match in time. E2F1 shows peak expression during G1/S, whereas Kv10.1 reaches a maximum during G2/M. The role of E2F1 in controlling the expression of genes important for cell cycle progression relies on both repression, when it forms part of the repressor complex together with $\mathrm{Rb}$, and activation. Although the majority of studies have focused on the role of E2F1 in controlling gene expression during G1/S, previous studies have provided evidence that E2F1 also controls the transcription of genes involved in later events, such as DNA repair and mitosis (Ishida, Huang et al. 2001, Ren, Cam et al. 2002, Polager and Ginsberg 2003, Zhu, Giangrande et al. 2004). Cyclin B and cyclin A, which are rate-limiting factors at the G2/M transition, are targets for E2F1 (Zhu, Giangrande et al. 2004). However, Cyclin A and B expression also diverge from Kv10.1 expression kinetics. Cyclin B for example, reaches a peak in $\mathrm{G} 2 / \mathrm{M}$ and declines upon activation of the anaphase promoting factor, before the end of mitosis. In contrast, Kv10.1 transcription is induced during G2/M, but the peak expression is reached after the completion of mitosis. This expression pattern indicates that although E2F1 activation is the triggering event, Kv10.1 is subject to a combination of additional regulatory mechanisms.

For example, posttranscriptional control mechanisms might also be implicated during this process. It is known that E2F1 activates ARF, which is a positive regulator of p53 (del Arroyo, El Messaoudi et al. 2007). Activation of p53, would in turn target miR34a, which, as already mentioned can bind directly to the 3'UTR of Kv10.1 promoter to suppress its expression and therefore delay its accumulation (Lin, Li et al. 2011). 
The mechanisms underlying Kv10.1 degradation could also contribute to Kv10.1 expression kinetics. The ubiquitin proteasome system (UPS) has emerged as a crucial intrinsic regulator of the cell cycle (Teixeira and Reed 2013). Yeast two-hybrid assays have revealed that the E3 ligase FBXO31-SCF (Skp1/Cullin-1/F-box protein) interacts with Kv10.1 (unpublished data). F-box proteins are interchangeable subunits of the Cullin-1 based E3 ubiquitin ligase, responsible for substrate recognition and recruitment. Interestingly, FBXO31-SCF localizes to the centrosome (Vadhvani, Schwedhelm-Domeyer et al. 2013), which is in close proximity to the primary cilium, since the basal body of the primary cilium originates there. Thus, if Kv10.1 helps in the promotion of cilium resorption, it could appear that Kv10.1 expression is regulated by the $\mathrm{Rb} / \mathrm{E} 2 \mathrm{~F} 1$ pathway during $\mathrm{G} 2 / \mathrm{M}$, just before the primary cilium disassembles, and once the cell exits the cell cycle, FBXO31-SCF would target Kv10.1 for degradation and favors primary cilium assembly. Nevertheless, this has to be studied in more detail. Our group has been able to detect interaction by coimmunoprecipitation assays only in one direction (IP: Kv10.1 / WB: FBXO31-SCF).

The tumor suppressor von Hippel-Lindau (VHL) is another E3 ligase, and it has been shown to support ciliary formation and maintenance (Kaelin 2008). Our group has reported that VHL promotes Kv10.1 ubiquitination (Downie 2009). A functional correlation has been reported between VHL expression and Kv10.1 current, Kv10.1 current density being reduced upon VHL expression in SH- SY5Y neuroblastoma cell line (Murata, Tajima et al. 2002). VHL contribution to cilium formation is also related to interaction with the hypoxia-inducible factor (HIF-1 $\alpha$ )/ Rabaptin5 axis. RPE-1 cells silenced for HIF-1 $\alpha$ fail to form primary cilium, this reduction of cilia formation is rescued by co-depletion of Rabaptin5 (Troilo, Alexander et al. 2014). Our group has shown physical and functional interaction of Kv10.1 with Rabaptin-5 (Ninkovic, 
Mitkovski et al. 2012), whereas only functional interaction between HIF-1 and Kv10.1 expression has also been reported. (Downie, Sanchez et al. 2008). Additionally, VHL loss of function induces the expression of the Aurora-A kinase (AURKA) and NEDD9 complex, both of them well known to induce ciliary resorption. NEDD9 regulates the actin cytoskeleton through cortactin deacetylation in an AURKA- dependent manner. NEDD9 deficiency leads to a decrease in the persistence and stability of lamellipodial protrusions, similar to the phenotype of cortactin knockdown (Kozyreva, McLaughlin et al. 2014). Kv10.1 has been shown to interact with cortactin (Herrmann, Ninkovic et al. 2012), and it is suggested that this interaction controls the abundance of Kv10.1 at the plasma membrane and is required for functional expression of Kv10.1 channels. Thus, it seems that Kv10.1 expression and stability in the membrane might be regulated by overlapping pathways controlling ciliary assembly/disassembly. This would also be compatible with the fast surface turnover that controls the subcellular distribution and life cycle of Kv10.1 described by Kohl et al. (2011). Moreover, these observations reinforce the idea of Kv10.1 as an active regulator of cell cycle progression. Kv10.1 appears then as a switch helping to regulate the assembly and disassembly of primary cilium, and therefore exit/entrance to the cell cycle.

\subsection{Summary}

Kv10.1 is a voltage dependent potassium channel. Its expression has been reported to be widespread in clinical tumors samples of diverse origin. In contrast, expression in normal non-neural tissue has been detected at low levels, and only in restricted populations of cells (Hemmerlein, Weseloh et al. 2006). Kv10.1 is shown to be associated with poor survival, and channel expression also appears to be increased 
upon mitogen factor stimulation (Borowiec, Hague et al. 2007), favors cell proliferation, and tumor progression (Pardo, del Camino et al. 1999, Weber, Mello de Queiroz et al. 2006, Downie, Sanchez et al. 2008). It is believed that tumor cells expressing Kv10.1 acquire selective advantages that allow them to maintain chronic proliferation.

Through this study we identified a dependency of Kv10.1 expression on cell cycle, and a possible mechanism underlying Kv10.1 expression in cancer cells. Kv10.1 is expressed at a defined, narrow time window during G2/M. The Rb/E2F1 pathway regulates its expression time course. $\mathrm{Rb} / \mathrm{E} 2 \mathrm{~F} 1$ complex represses transcription of Kv10.1, and the disruption of the Rb/E2F1 complex by HPV-E7 leads to release of E2F1 transcription factor, which directly binds to $K v 10.1 p r$ to activate transcription. Furthermore, we show that in asynchronous HeLa cells, Kv10.1 knockdown increases the $\mathrm{G} 2 / \mathrm{M}$ fraction, suggesting that in the absence of Kv10.1 cells spend, on average, more time in G2/M. Finally, taking into account Kv10.1 expression kinetics, we found Kv10.1 expression in normal non-neuronal tissue. A proliferating population of cells located at the bottom and sides of colonic crypts is positive for Kv10.1.

These findings can help mechanistically explain the influence of Kv10.1 on tumor cell proliferation and its aberrant expression in tumors. The results reinforce the idea of Kv10.1 as a switch that participates in the regulation, assembly and disassembly of the primary cilium, and therefore controls the exit and entrance into the cell cycle. 


\section{REFERENCES}

Adaixo, R., C. A. Harley, A. F. Castro-Rodrigues and J. H. Morais-Cabral (2013). "Structural properties of PAS domains from the KCNH potassium channels." PLoS One 8(3): e59265.

Agarwal, J. R., F. Griesinger, W. Stuhmer and L. A. Pardo (2010). "The potassium channel Ether a go-go is a novel prognostic factor with functional relevance in acute myeloid leukemia." Mol Cancer 9: 18.

Andersen, A. S., A. S. Koldjaer Solling, T. Ovesen and M. Rusan (2013). "The interplay between HPV and host immunity in head and neck squamous cell carcinoma." Int J Cancer.

Asher, V., R. Khan, A. Warren, R. Shaw, G. V. Schalkwyk, A. Bali and H. M. Sowter (2010). "The Eag potassium channel as a new prognostic marker in ovarian cancer." Diagn Pathol 5: 78.

Bauer, C. K. and J. R. Schwarz (2001). "Physiology of EAG K+ channels." J Membr Biol 182(1): 1-15.

Bernheim, L., J. H. Liu, M. Hamann, C. A. Haenggeli, J. Fischer-Lougheed and C. R. Bader (1996). "Contribution of a non-inactivating potassium current to the resting membrane potential of fusion-competent human myoblasts." J Physiol 493 ( Pt 1): $129-141$. 
Bijlenga, P., T. Occhiodoro, J. H. Liu, C. R. Bader, L. Bernheim and J. FischerLougheed (1998). "An ether -a-go-go K+ current, Ih-eag, contributes to the hyperpolarization of human fusion-competent myoblasts." J Physiol 512 ( Pt 2): 317323.

Blackiston, D. J., K. A. McLaughlin and M. Levin (2009). "Bioelectric controls of cell proliferation: ion channels, membrane voltage and the cell cycle." Cell Cycle 8(21): $3519-3528$.

Borowiec, A. S., F. Hague, V. Gouilleux-Gruart, K. Lassoued and H. OuadidAhidouch (2011). "Regulation of IGF-1-dependent cyclin D1 and E expression by hEag1 channels in MCF-7 cells: the critical role of hEag1 channels in G1 phase progression." Biochim Biophys Acta 1813(5): 723-730.

Borowiec, A. S., F. Hague, N. Harir, S. Guenin, F. Guerineau, F. Gouilleux, M. Roudbaraki, K. Lassoued and H. Ouadid-Ahidouch (2007). "IGF-1 activates hEAG $\mathrm{K}(+)$ channels through an Akt-dependent signaling pathway in breast cancer cells: role in cell proliferation." J Cell Physiol 212(3): 690-701.

Brelidze, T. I., A. E. Carlson, B. Sankaran and W. N. Zagotta (2012). "Structure of the carboxy-terminal region of a KCNH channel." Nature 481(7382): 530-533.

Bruggemann, A., L. A. Pardo, W. Stuhmer and O. Pongs (1993). "Ether-a-go-go encodes a voltage-gated channel permeable to $\mathrm{K}+$ and $\mathrm{Ca} 2+$ and modulated by cAMP." Nature 365(6445): 445-448. 
Bruggemann, A., W. Stuhmer and L. A. Pardo (1997). "Mitosis-promoting factormediated suppression of a cloned delayed rectifier potassium channel expressed in Xenopus oocytes." Proc Natl Acad Sci U S A 94(2): 537-542.

Burke, J. R., T. J. Liban, T. Restrepo, H. W. Lee and S. M. Rubin (2014). "Multiple mechanisms for E2F binding inhibition by phosphorylation of the retinoblastoma protein C-terminal domain." J Mol Biol 426(1): 245-255.

Carignani, C. and M. Corsi (2002). "Inhibition of SK3 channels in the TE671 human medulloblastoma cell line by desipramine and imipramine." Eur J Pharmacol 448(23): $139-142$.

Carriere, C., A. J. Gore, A. M. Norris, J. R. Gunn, A. L. Young, D. S. Longnecker and M. Korc (2011). "Deletion of Rb accelerates pancreatic carcinogenesis by oncogenic Kras and impairs senescence in premalignant lesions." Gastroenterology 141(3): 1091-1101.

Cen, L., B. L. Carlson, M. A. Schroeder, J. L. Ostrem, G. J. Kitange, A. C. Mladek, S. R. Fink, P. A. Decker, W. Wu, J. S. Kim, T. Waldman, R. B. Jenkins and J. N. Sarkaria (2012). "p16-Cdk4-Rb axis controls sensitivity to a cyclin-dependent kinase inhibitor PD0332991 in glioblastoma xenograft cells." Neuro Oncol 14(7): 870-881.

Chen, T., P. A. Stephens, F. K. Middleton and N. J. Curtin (2012). "Targeting the S and G2 checkpoint to treat cancer." Drug Discov Today 17(5-6): 194-202. 
Chen, Y., A. Sanchez, M. E. Rubio, T. Kohl, L. A. Pardo and W. Stuhmer (2011). "Functional K(v)10.1 channels localize to the inner nuclear membrane." PLoS One 6(5): e19257.

Coe, B. P., K. L. Thu, S. Aviel-Ronen, E. A. Vucic, A. F. Gazdar, S. Lam, M. S. Tsao and W. L. Lam (2013). "Genomic deregulation of the E2F/Rb pathway leads to activation of the oncogene EZH2 in small cell lung cancer." PLoS One 8(8): e71670.

Cone, C. D., Jr. (1971). "Unified theory on the basic mechanism of normal mitotic control and oncogenesis." J Theor Biol 30(1): 151-181.

Cunha, L. C., E. Del Bel, L. Pardo, W. Stuhmer and D. E. A. R. Titze (2013). "RNA interference with EAG1 enhances interferon gamma injury to glioma cells in vitro." Anticancer Res 33(3): 865-870.

Dai, Y. and S. Grant (2010). "New insights into checkpoint kinase 1 in the DNA damage response signaling network." Clin Cancer Res 16(2): 376-383.

Darnell, G. A., W. A. Schroder, T. M. Antalis, E. Lambley, L. Major, J. Gardner, G. Birrell, A. Cid-Arregui and A. Suhrbier (2007). "Human papillomavirus E7 requires the protease calpain to degrade the retinoblastoma protein." J Biol Chem 282(52): $37492-37500$. 
del Arroyo, A. G., S. El Messaoudi, P. A. Clark, M. James, F. Stott, A. Bracken, K. Helin and G. Peters (2007). "E2F-dependent induction of p14ARF during cell cycle re-entry in human T cells." Cell Cycle 6(21): 2697-2705.

del Pliego, M. G., E. Aguirre-Benitez, K. Paisano-Ceron, I. Valdovinos-Ramirez, C. Rangel-Morales, V. Rodriguez-Mata, C. Solano-Agama, D. Martin-Tapia, M. T. de la Vega, M. Saldoval-Balanzario, J. Camacho and M. E. Mendoza-Garrido (2013). "Expression of Eag1 K+ channel and ErbBs in human pituitary adenomas: cytoskeleton arrangement patterns in cultured cells." Int J Clin Exp Pathol 6(3): 458468.

Diaz, L., I. Ceja-Ochoa, I. Restrepo-Angulo, F. Larrea, E. Avila-Chavez, R. GarciaBecerra, E. Borja-Cacho, D. Barrera, E. Ahumada, P. Gariglio, E. Alvarez-Rios, R. Ocadiz-Delgado, E. Garcia-Villa, E. Hernandez-Gallegos, I. Camacho-Arroyo, A. Morales, D. Ordaz-Rosado, E. Garcia-Latorre, J. Escamilla, L. C. Sanchez-Pena, M. Saqui-Salces, A. Gamboa-Dominguez, E. Vera, M. Uribe-Ramirez, J. Murbartian, C. S. Ortiz, C. Rivera-Guevara, A. De Vizcaya-Ruiz and J. Camacho (2009). "Estrogens and human papilloma virus oncogenes regulate human ether-a-go-go-1 potassium channel expression." Cancer Res 69(8): 3300-3307.

Ding, X. W., H. S. Luo, X. Jin, J. J. Yan and Y. W. Ai (2007). "Aberrant expression of Eag1 potassium channels in gastric cancer patients and cell lines." Med Oncol 24(3): 345-350. 
Ding, X. W., X. G. Wang, H. S. Luo, S. Y. Tan, S. Gao, B. Luo and H. Jiang (2008). "Expression and prognostic roles of Eag1 in resected esophageal squamous cell carcinomas." Dig Dis Sci 53(8): 2039-2044.

Ding, X. W., J. J. Yan, P. An, P. Lu and H. S. Luo (2007). "Aberrant expression of ether a go-go potassium channel in colorectal cancer patients and cell lines." World J Gastroenterol 13(8): 1257-1261.

Docquier, A., P. Augereau, M. Lapierre, P. O. Harmand, E. Badia, J. S. Annicotte, L. Fajas and V. Cavailles (2012). "The RIP140 gene is a transcriptional target of E2F1." PLoS One 7(5): e35839.

Downie, B. (2009). Participation of Eag1 in tumor relevant pathways., Georg-August Universität, Göttingen.

Downie, B. R., A. Sanchez, H. Knotgen, C. Contreras-Jurado, M. Gymnopoulos, C. Weber, W. Stuhmer and L. A. Pardo (2008). "Eag1 expression interferes with hypoxia

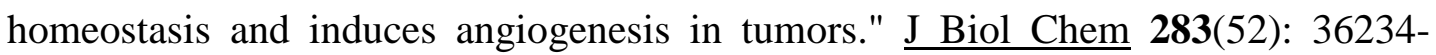
36240.

Dufourny, B., J. Alblas, H. A. van Teeffelen, F. M. van Schaik, B. van der Burg, P. H. Steenbergh and J. S. Sussenbach (1997). "Mitogenic signaling of insulin-like growth factor I in MCF-7 human breast cancer cells requires phosphatidylinositol 3-kinase and is independent of mitogen-activated protein kinase." J Biol Chem 272(49): 3116331171. 
Dupont, J. and D. Le Roith (2001). "Insulin-like growth factor 1 and oestradiol promote cell proliferation of MCF-7 breast cancer cells: new insights into their synergistic effects." Mol Pathol 54(3): 149-154.

Ertel, A., J. L. Dean, H. Rui, C. Liu, A. K. Witkiewicz, K. E. Knudsen and E. S. Knudsen (2010). "RB-pathway disruption in breast cancer: differential association with disease subtypes, disease-specific prognosis and therapeutic response." $\underline{\text { Cell }}$ Cycle 9(20): 4153-4163.

Eymin, B., S. Gazzeri, C. Brambilla and E. Brambilla (2001). "Distinct pattern of E2F1 expression in human lung tumours: E2F1 is upregulated in small cell lung carcinoma." Oncogene 20(14): 1678-1687.

Farias, L. M., D. B. Ocana, L. Diaz, F. Larrea, E. Avila-Chavez, A. Cadena, L. M. Hinojosa, G. Lara, L. A. Villanueva, C. Vargas, E. Hernandez-Gallegos, I. CamachoArroyo, A. Duenas-Gonzalez, E. Perez-Cardenas, L. A. Pardo, A. Morales, L. TajaChayeb, J. Escamilla, C. Sanchez-Pena and J. Camacho (2004). "Ether a go-go potassium channels as human cervical cancer markers." Cancer Res 64(19): 69967001.

Farnham, P. J. (2009). "Insights from genomic profiling of transcription factors." Nat Rev Genet 10(9): 605-616. 
Faust, D., C. Schmitt, F. Oesch, B. Oesch-Bartlomowicz, I. Schreck, C. Weiss and C. Dietrich (2012). "Differential p38-dependent signalling in response to cellular stress and mitogenic stimulation in fibroblasts." Cell Commun Signal 10: 6.

Foster, D. A., P. Yellen, L. Xu and M. Saqcena (2010). "Regulation of G1 Cell Cycle Progression: Distinguishing the Restriction Point from a Nutrient-Sensing Cell Growth Checkpoint(s)." Genes Cancer 1(11): 1124-1131.

Garcia-Ferreiro, R. E., D. Kerschensteiner, F. Major, F. Monje, W. Stuhmer and L. A. Pardo (2004). "Mechanism of block of hEag1 K+ channels by imipramine and astemizole." J Gen Physiol 124(4): 301-317.

Gavrilova-Ruch, O., K. Schonherr, G. Gessner, R. Schonherr, T. Klapperstuck, W. Wohlrab and S. H. Heinemann (2002). "Effects of imipramine on ion channels and proliferation of IGR1 melanoma cells." J Membr Biol 188(2): 137-149.

Gomez-Varela, D., T. Kohl, M. Schmidt, M. E. Rubio, H. Kawabe, R. B. Nehring, S. Schafer, W. Stuhmer and L. A. Pardo (2010). "Characterization of Eag1 channel lateral mobility in rat hippocampal cultures by single-particle-tracking with quantum dots." PLoS One 5(1): e8858.

Gomez-Varela, D., E. Zwick-Wallasch, H. Knotgen, A. Sanchez, T. Hettmann, D. Ossipov, R. Weseloh, C. Contreras-Jurado, M. Rothe, W. Stuhmer and L. A. Pardo (2007). "Monoclonal antibody blockade of the human Eag1 potassium channel function exerts antitumor activity." Cancer Res 67(15): 7343-7349. 
Goncalves, J. T. and W. Stuhmer (2010). "Calmodulin interaction with hEAG1 visualized by FRET microscopy." PLoS One 5(5): e10873.

Gorbe, A., D. L. Becker, L. Dux, L. Krenacs and T. Krenacs (2006). "In differentiating prefusion myoblasts connexin43 gap junction coupling is upregulated before myoblast alignment then reduced in post-mitotic cells." Histochem Cell Biol 125(6): 705-716.

Gorgoulis, V. G., P. Zacharatos, G. Mariatos, A. Kotsinas, M. Bouda, D. Kletsas, P. J. Asimacopoulos, N. Agnantis, C. Kittas and A. G. Papavassiliou (2002). "Transcription factor E2F-1 acts as a growth-promoting factor and is associated with adverse prognosis in non-small cell lung carcinomas." J Pathol 198(2): 142-156.

Gutman, G. A., K. G. Chandy, S. Grissmer, M. Lazdunski, D. McKinnon, L. A. Pardo, G. A. Robertson, B. Rudy, M. C. Sanguinetti, W. Stuhmer and X. Wang (2005). "International Union of Pharmacology. LIII. Nomenclature and molecular relationships of voltage-gated potassium channels." Pharmacol Rev 57(4): 473-508.

Haitin, Y., A. E. Carlson and W. N. Zagotta (2013). "The structural mechanism of KCNH-channel regulation by the eag domain." Nature 501(7467): 444-448.

Han, S., K. Park, B. N. Bae, K. H. Kim, H. J. Kim, Y. D. Kim and H. Y. Kim (2003). "E2F1 expression is related with the poor survival of lymph node-positive breast cancer patients treated with fluorouracil, doxorubicin and cyclophosphamide." Breast Cancer Res Treat 82(1): 11-16. 
Hanahan, D. and R. A. Weinberg (2011). "Hallmarks of cancer: the next generation." Cell 144(5): 646-674.

Harbour, J. W. and D. C. Dean (2000). "The Rb/E2F pathway: expanding roles and emerging paradigms." Genes Dev 14(19): 2393-2409.

Harper, J. V. (2005). "Synchronization of cell populations in G1/S and G2/M phases of the cell cycle." Methods Mol Biol 296: 157-166.

Hartung, F., W. Stuhmer and L. A. Pardo (2011). "Tumor cell-selective apoptosis induction through targeting of $\mathrm{K}(\mathrm{V}) 10.1$ via bifunctional TRAIL antibody." $\underline{\text { Mol }}$ Cancer 10: 109.

Hartwell, L. H., J. Culotti, J. R. Pringle and B. J. Reid (1974). "Genetic control of the cell division cycle in yeast." Science 183(4120): 46-51.

Hartwell, L. H. and T. A. Weinert (1989). "Checkpoints: controls that ensure the order of cell cycle events." Science 246(4930): 629-634.

Hegle, A. P., D. D. Marble and G. F. Wilson (2006). "A voltage-driven switch for ionindependent signaling by ether-a-go-go K+ channels." Proc Natl Acad Sci U S A 103(8):

2886-2891.

Hemmerlein, B., R. M. Weseloh, F. Mello de Queiroz, H. Knotgen, A. Sanchez, M. E. Rubio, S. Martin, T. Schliephacke, M. Jenke, R. Heinz Joachim, W. Stuhmer and 
L. A. Pardo (2006). "Overexpression of Eag1 potassium channels in clinical tumours." Mol Cancer 5: 41.

Henry, J. T. and S. Crosson (2011). "Ligand-binding PAS domains in a genomic, cellular, and structural context." Annu Rev Microbiol 65: 261-286.

Herrmann, S., M. Ninkovic, T. Kohl, E. Lorinczi and L. A. Pardo (2012). "Cortactin controls surface expression of the voltage-gated potassium channel $\mathrm{K}(\mathrm{V}) 10.1$." $\underline{\mathrm{J} \text { Biol }}$ Chem 287(53): 44151-44163.

Hindi, S. M., M. M. Tajrishi and A. Kumar (2013). "Signaling mechanisms in mammalian myoblast fusion." Sci Signal 6(272): re2.

Humphries, A. and N. A. Wright (2008). "Colonic crypt organization and tumorigenesis." Nat Rev Cancer 8(6): 415-424.

Ishida, S., E. Huang, H. Zuzan, R. Spang, G. Leone, M. West and J. R. Nevins (2001). "Role for E2F in control of both DNA replication and mitotic functions as revealed from DNA microarray analysis." Mol Cell Biol 21(14): 4684-4699.

Jacks, T., A. Fazeli, E. M. Schmitt, R. T. Bronson, M. A. Goodell and R. A. Weinberg (1992). "Effects of an Rb mutation in the mouse." Nature 359(6393): 295-300.

Jenke, M., A. Sanchez, F. Monje, W. Stuhmer, R. M. Weseloh and L. A. Pardo (2003). "C-terminal domains implicated in the functional surface expression of potassium channels." EMBO J 22(3): 395-403. 
Johnson, D. G. and J. Degregori (2006). "Putting the Oncogenic and Tumor Suppressive Activities of E2F into Context." Curr Mol Med 6(7): 731-738.

Johnson, D. G., K. Ohtani and J. R. Nevins (1994). "Autoregulatory control of E2F1 expression in response to positive and negative regulators of cell cycle progression." Genes Dev 8(13): 1514-1525.

Kaelin, W. G., Jr. (2008). "The von Hippel-Lindau tumour suppressor protein: O2 sensing and cancer." Nat Rev Cancer 8(11): 865-873.

Kohl, T., E. Lorinczi, L. A. Pardo and W. Stuhmer (2011). "Rapid internalization of the oncogenic K+ channel K(V)10.1." PLoS One 6(10): e26329.

Konig, S., A. Beguet, C. R. Bader and L. Bernheim (2006). "The calcineurin pathway links hyperpolarization (Kir2.1)-induced $\mathrm{Ca} 2+$ signals to human myoblast differentiation and fusion." Development 133(16): 3107-3114.

Kosinski, C., V. S. Li, A. S. Chan, J. Zhang, C. Ho, W. Y. Tsui, T. L. Chan, R. C. Mifflin, D. W. Powell, S. T. Yuen, S. Y. Leung and X. Chen (2007). "Gene expression patterns of human colon tops and basal crypts and BMP antagonists as intestinal stem cell niche factors." Proc Natl Acad Sci U S A 104(39): 15418-15423.

Kozyreva, V. K., S. L. McLaughlin, R. H. Livengood, R. A. Calkins, L. C. Kelley, A. Rajulapati, R. J. Ice, M. B. Smolkin, S. A. Weed and E. N. Pugacheva (2014). 
"NEDD9 Regulates Actin Dynamics through Cortactin Deacetylation in an AURKA/HDAC6-dependent Manner." Mol Cancer Res.

Lallet-Daher, H., M. Roudbaraki, A. Bavencoffe, P. Mariot, F. Gackiere, G. Bidaux, R. Urbain, P. Gosset, P. Delcourt, L. Fleurisse, C. Slomianny, E. Dewailly, B. Mauroy, J. L. Bonnal, R. Skryma and N. Prevarskaya (2009). "Intermediate-conductance Ca2+activated $\mathrm{K}+$ channels (IKCa1) regulate human prostate cancer cell proliferation through a close control of calcium entry." Oncogene 28(15): 1792-1806.

Lee, Y. S., M. M. Sayeed and R. D. Wurster (1993). "Inhibition of cell growth by K+ channel modulators is due to interference with agonist-induced $\mathrm{Ca} 2+$ release." $\underline{\text { Cell }}$ Signal 5(6): 803-809.

Lepple-Wienhues, A., S. Berweck, M. Bohmig, C. P. Leo, B. Meyling, C. Garbe and M. Wiederholt (1996). "K+ channels and the intracellular calcium signal in human melanoma cell proliferation." J Membr Biol 151(2): 149-157.

Li, Q., S. Gayen, A. S. Chen, Q. Huang, M. Raida and C. Kang (2010). "NMR solution structure of the N-terminal domain of hERG and its interaction with the S4-S5 linker." Biochem Biophys Res Commun 403(1): 126-132.

Lim, S. and P. Kaldis (2013). "Cdks, cyclins and CKIs: roles beyond cell cycle regulation." Development 140(15): 3079-3093. 
Lin, C. S., R. C. Boltz, J. T. Blake, M. Nguyen, A. Talento, P. A. Fischer, M. S. Springer, N. H. Sigal, R. S. Slaughter, M. L. Garcia and et al. (1993). "Voltage-gated potassium channels regulate calcium-dependent pathways involved in human $\mathrm{T}$ lymphocyte activation." J Exp Med 177(3): 637-645.

Lin, H., Z. Li, C. Chen, X. Luo, J. Xiao, D. Dong, Y. Lu, B. Yang and Z. Wang (2011). "Transcriptional and post-transcriptional mechanisms for oncogenic overexpression of ether a go-go K+ channel." PLoS One 6(5): e20362.

Liu, J. H., P. Bijlenga, J. Fischer-Lougheed, T. Occhiodoro, A. Kaelin, C. R. Bader and L. Bernheim (1998). "Role of an inward rectifier $\mathrm{K}+$ current and of hyperpolarization in human myoblast fusion." J Physiol 510 ( Pt 2): 467-476.

Livak, K. J. and T. D. Schmittgen (2001). "Analysis of relative gene expression data using real-time quantitative PCR and the 2(-Delta Delta C(T)) Method." Methods 25(4): 402-408.

Ludwig, J., H. Terlau, F. Wunder, A. Bruggemann, L. A. Pardo, A. Marquardt, W. Stuhmer and O. Pongs (1994). "Functional expression of a rat homologue of the voltage gated either a go-go potassium channel reveals differences in selectivity and activation kinetics between the Drosophila channel and its mammalian counterpart." EMBO J 13(19): 4451-4458.

Malumbres, M. and M. Barbacid (2009). "Cell cycle, CDKs and cancer: a changing paradigm." Nat Rev Cancer 9(3): 153-166. 
Marques-Carvalho, M. J., N. Sahoo, F. W. Muskett, R. S. Vieira-Pires, G. Gabant, M. Cadene, R. Schonherr and J. H. Morais-Cabral (2012). "Structural, biochemical, and functional characterization of the cyclic nucleotide binding homology domain from the mouse EAG1 potassium channel." J Mol Biol 423(1): 34-46.

Martin, S., C. Lino de Oliveira, F. Mello de Queiroz, L. A. Pardo, W. Stuhmer and E. Del Bel (2008). "Eag1 potassium channel immunohistochemistry in the CNS of adult rat and selected regions of human brain." Neuroscience 155(3): 833-844.

McIntosh, B. E., J. B. Hogenesch and C. A. Bradfield (2010). "Mammalian Per-ArntSim proteins in environmental adaptation." Annu Rev Physiol 72: 625-645.

Mello de Queiroz, F., G. Suarez-Kurtz, W. Stuhmer and L. A. Pardo (2006). "Ether a go-go potassium channel expression in soft tissue sarcoma patients." Mol Cancer 5: 42.

Menendez, S. T., M. A. Villaronga, J. P. Rodrigo, S. Alvarez-Teijeiro, D. GarciaCarracedo, R. G. Urdinguio, M. F. Fraga, L. A. Pardo, C. G. Viloria, C. Suarez and J. M. Garcia-Pedrero (2012). "Frequent aberrant expression of the human ether a go-go (hEAG1) potassium channel in head and neck cancer: pathobiological mechanisms and clinical implications." J Mol Med (Berl) 90(10): 1173-1184.

Mettus, R. V. and S. G. Rane (2003). "Characterization of the abnormal pancreatic development, reduced growth and infertility in Cdk4 mutant mice." Oncogene 22(52): 8413-8421. 
Meyer, R. and S. H. Heinemann (1998). "Characterization of an eag-like potassium channel in human neuroblastoma cells." J Physiol 508 ( Pt 1): 49-56.

Moody, C. A. and L. A. Laimins (2010). "Human papillomavirus oncoproteins: pathways to transformation." Nat Rev Cancer 10(8): 550-560.

Morais Cabral, J. H., A. Lee, S. L. Cohen, B. T. Chait, M. Li and R. Mackinnon (1998). "Crystal structure and functional analysis of the HERG potassium channel $\mathrm{N}$ terminus: a eukaryotic PAS domain." Cell 95(5): 649-655.

Mortensen LS (2012). Modulation of synaptic transmission by the voltage-gated potassium channel Eag1. Doktor rerum naturalium, Georg-August-Universtät.

Munger, K., W. C. Phelps, V. Bubb, P. M. Howley and R. Schlegel (1989). "The E6 and E7 genes of the human papillomavirus type 16 together are necessary and sufficient for transformation of primary human keratinocytes." J Virol 63(10): 44174421.

Murata, H., N. Tajima, Y. Nagashima, M. Yao, M. Baba, M. Goto, S. Kawamoto, I. Yamamoto, K. Okuda and H. Kanno (2002). "Von Hippel-Lindau tumor suppressor protein transforms human neuroblastoma cells into functional neuron-like cells." Cancer Res 62(23): 7004-7011.

Murray, A. W. (1992). "Creative blocks: cell-cycle checkpoints and feedback controls." Nature 359(6396): 599-604. 
Ninkovic, M., M. Mitkovski, T. Kohl, W. Stuhmer and L. A. Pardo (2012). "Physical and functional interaction of KV10.1 with Rabaptin-5 impacts ion channel trafficking." FEBS Lett 586(19): 3077-3084.

Occhiodoro, T., L. Bernheim, J. H. Liu, P. Bijlenga, M. Sinnreich, C. R. Bader and J. Fischer-Lougheed (1998). "Cloning of a human ether-a-go-go potassium channel expressed in myoblasts at the onset of fusion." FEBS Lett 434(1-2): 177-182.

Ouadid-Ahidouch, H., X. Le Bourhis, M. Roudbaraki, R. A. Toillon, P. Delcourt and N. Prevarskaya (2001). "Changes in the K+ current-density of MCF-7 cells during progression through the cell cycle: possible involvement of a h-ether.a-gogo $\mathrm{K}+$ channel." Receptors Channels 7(5): 345-356.

Ousingsawat, J., M. Spitzner, S. Puntheeranurak, L. Terracciano, L. Tornillo, L. Bubendorf, K. Kunzelmann and R. Schreiber (2007). "Expression of voltage-gated potassium channels in human and mouse colonic carcinoma." Clin Cancer Res 13(3): 824-831.

Pan, J., T. Seeger-Nukpezah and E. A. Golemis (2013). "The role of the cilium in normal and abnormal cell cycles: emphasis on renal cystic pathologies." Cell Mol Life Sci 70(11): 1849-1874.

Pardo, L. A., A. Bruggemann, J. Camacho and W. Stuhmer (1998). "Cell cycle-related changes in the conducting properties of r-eag K+ channels." J Cell Biol 143(3): 767775. 
Pardo, L. A., D. del Camino, A. Sanchez, F. Alves, A. Bruggemann, S. Beckh and W. Stuhmer (1999). "Oncogenic potential of EAG K(+) channels." EMBO J 18(20): $5540-5547$.

Patt, S., K. Preussat, C. Beetz, R. Kraft, M. Schrey, R. Kalff, K. Schonherr and S. H. Heinemann (2004). "Expression of ether a go-go potassium channels in human gliomas." Neurosci Lett 368(3): 249-253.

Pierce, A. M., R. Schneider-Broussard, I. B. Gimenez-Conti, J. L. Russell, C. J. Conti and D. G. Johnson (1999). "E2F1 has both oncogenic and tumor-suppressive properties in a transgenic model." Mol Cell Biol 19(9): 6408-6414.

Pines, J. and T. Hunter (1991). "Human cyclins A and B1 are differentially located in the cell and undergo cell cycle-dependent nuclear transport." J Cell Biol 115(1): 1-17.

Pines, J. and T. Hunter (1994). "The differential localization of human cyclins A and $\mathrm{B}$ is due to a cytoplasmic retention signal in cyclin B." EMBO J 13(16): 3772-3781.

Polager, S. and D. Ginsberg (2003). "E2F mediates sustained G2 arrest and downregulation of Stathmin and AIM-1 expression in response to genotoxic stress." J Biol Chem 278(3): 1443-1449.

Porter, L. A. and D. J. Donoghue (2003). "Cyclin B1 and CDK1: nuclear localization and upstream regulators." Prog Cell Cycle Res 5: 335-347. 
Pozarowski, P. and Z. Darzynkiewicz (2004). "Analysis of cell cycle by flow cytometry." Methods Mol Biol 281: 301-311.

Ramshankar, V. and A. Krishnamurthy (2013). "Human Papilloma Virus in Head and Neck Cancers-Role and Relevance in Clinical Management." Indian J Surg Oncol 4(1): 59-66.

Rayman, J. B., Y. Takahashi, V. B. Indjeian, J. H. Dannenberg, S. Catchpole, R. J. Watson, H. te Riele and B. D. Dynlacht (2002). "E2F mediates cell cycle-dependent transcriptional repression in vivo by recruitment of an HDAC $1 / \mathrm{mSin} 3 \mathrm{~B}$ corepressor complex." Genes Dev 16(8): 933-947.

Reichard, P. (1988). "Interactions between deoxyribonucleotide and DNA synthesis." Annu Rev Biochem 57: 349-374.

Ren, B., H. Cam, Y. Takahashi, T. Volkert, J. Terragni, R. A. Young and B. D. Dynlacht (2002). "E2F integrates cell cycle progression with DNA repair, replication, and G(2)/M checkpoints." Genes Dev 16(2): 245-256.

Rieder, C. L. (2011). "Mitosis in vertebrates: the G2/M and M/A transitions and their associated checkpoints." Chromosome Res 19(3): 291-306.

Robertson, G. A., J. M. Warmke and B. Ganetzky (1996). "Potassium currents expressed from Drosophila and mouse eag cDNAs in Xenopus oocytes." Neuropharmacology 35(7): 841-850. 
Rochlin, K., S. Yu, S. Roy and M. K. Baylies (2010). "Myoblast fusion: when it takes more to make one." Dev Biol 341(1): 66-83.

Rodriguez-Rasgado, J. A., I. Acuna-Macias and J. Camacho (2012). "Eag1 channels as potential cancer biomarkers." Sensors (Basel) 12(5): 5986-5995.

Rubin, S. M., A. L. Gall, N. Zheng and N. P. Pavletich (2005). "Structure of the Rb C-terminal domain bound to E2F1-DP1: a mechanism for phosphorylation-induced E2F release." Cell 123(6): 1093-1106.

Russell, J. L., R. L. Weaks, T. R. Berton and D. G. Johnson (2006). "E2F1 suppresses skin carcinogenesis via the ARF-p53 pathway." Oncogene 25(6): 867-876.

Saito, M., K. Helin, M. B. Valentine, B. B. Griffith, C. L. Willman, E. Harlow and A. T. Look (1995). "Amplification of the E2F1 transcription factor gene in the HEL erythroleukemia cell line." Genomics 25(1): 130-138.

Sánchez, A., D. Urrego and L. Pardo (2014). "Cell cycle-dependent expression of Kv10.1 potassium channel regulates ciliogenesis."

Schindelin, J. (2008). "Fiji is just imagej."

Schonherr, R., K. Lober and S. H. Heinemann (2000). "Inhibition of human ether a go-go potassium channels by $\mathrm{Ca}(2+) /$ calmodulin." EMBO J 19(13): 3263-3271. 
Seeley, E. S. and M. V. Nachury (2010). "The perennial organelle: assembly and disassembly of the primary cilium." J Cell Sci 123(Pt 4): 511-518.

Sellers, W. R., B. G. Novitch, S. Miyake, A. Heith, G. A. Otterson, F. J. Kaye, A. B. Lassar and W. G. Kaelin, Jr. (1998). "Stable binding to E2F is not required for the retinoblastoma protein to activate transcription, promote differentiation, and suppress tumor cell growth." Genes Dev 12(1): 95-106.

Shaker, A. and D. C. Rubin (2010). "Intestinal stem cells and epithelial-mesenchymal interactions in the crypt and stem cell niche." Transl Res 156(3): 180-187.

Shema, E., I. Tirosh, Y. Aylon, J. Huang, C. Ye, N. Moskovits, N. Raver-Shapira, N. Minsky, J. Pirngruber, G. Tarcic, P. Hublarova, L. Moyal, M. Gana-Weisz, Y. Shiloh, Y. Yarden, S. A. Johnsen, B. Vojtesek, S. L. Berger and M. Oren (2008). "The histone H2B-specific ubiquitin ligase RNF20/hBRE1 acts as a putative tumor suppressor through selective regulation of gene expression." Genes Dev 22(19): 2664-2676.

Sherr, C. J. and F. McCormick (2002). "The RB and p53 pathways in cancer." Cancer Cell 2(2): 103-112.

Suckow, A. (2003). Charakterisierung von Ionenkanälen der ether- à-go-go- Familie, Georg-August- Universität zu Göttingen.

Suryadinata, R., M. Sadowski, R. Steel and B. Sarcevic (2011). "Cyclin-dependent kinase-mediated phosphorylation of RBP1 and $\mathrm{pRb}$ promotes their dissociation to 
mediate release of the SAP30.mSin3.HDAC transcriptional repressor complex." J Biol Chem 286(7): 5108-5118.

Suzuki, T., W. Yasui, H. Yokozaki, K. Naka, T. Ishikawa and E. Tahara (1999). "Expression of the E2F family in human gastrointestinal carcinomas." Int J Cancer 81(4): 535-538.

Takahashi, Y., J. B. Rayman and B. D. Dynlacht (2000). "Analysis of promoter binding by the $\mathrm{E} 2 \mathrm{~F}$ and $\mathrm{pRB}$ families in vivo: distinct $\mathrm{E} 2 \mathrm{~F}$ proteins mediate activation and repression." Genes Dev 14(7): 804-816.

Takaki, T., K. Fukasawa, I. Suzuki-Takahashi and H. Hirai (2004). "Cdk-mediated phosphorylation of pRB regulates HDAC binding in vitro." Biochem Biophys Res Commun 316(1): 252-255.

Teixeira, L. K. and S. I. Reed (2013). "Ubiquitin ligases and cell cycle control." Annu Rev Biochem 82: 387-414.

Terlau, H., S. H. Heinemann, W. Stuhmer, O. Pongs and J. Ludwig (1997). "Amino terminal-dependent gating of the potassium channel rat eag is compensated by a mutation in the S4 segment." J Physiol 502 ( Pt 3): 537-543.

Terlau, H., J. Ludwig, R. Steffan, O. Pongs, W. Stuhmer and S. H. Heinemann (1996). "Extracellular Mg2+ regulates activation of rat eag potassium channel." Pflugers Arch 432(2): 301-312. 
Troilo, A., I. Alexander, S. Muehl, D. Jaramillo, K. P. Knobeloch and W. Krek (2014). "HIF1alpha deubiquitination by USP8 is essential for ciliogenesis in normoxia." EMBO Rep 15(1): 77-85.

Ufartes, R., T. Schneider, L. S. Mortensen, C. de Juan Romero, K. Hentrich, H. Knoetgen, V. Beilinson, W. Moebius, V. Tarabykin, F. Alves, L. A. Pardo, J. N. Rawlins and W. Stuehmer (2013). "Behavioural and functional characterization of Kv10.1 (Eag1) knockout mice." Hum Mol Genet 22(11): 2247-2262.

Urrego, D., A. P. Tomczak, F. Zahed, W. Stühmer and L. A. Pardo (2014). "Potassium channels in cell cycle and cell proliferation." Philosophical Transactions of the Royal Society B: Biological Sciences 369(1638).

Vadhvani, M., N. Schwedhelm-Domeyer, C. Mukherjee and J. Stegmuller (2013). "The centrosomal E3 ubiquitin ligase FBXO31-SCF regulates neuronal morphogenesis and migration." PLoS One 8(2): e57530.

Vanhaesebroeck, B. and D. R. Alessi (2000). "The PI3K-PDK1 connection: more than just a road to PKB." Biochem J 346 Pt 3: 561-576.

Weber, C., F. Mello de Queiroz, B. R. Downie, A. Suckow, W. Stuhmer and L. A. Pardo (2006). "Silencing the activity and proliferative properties of the human EagI Potassium Channel by RNA Interference." J Biol Chem 281(19): 13030-13037. 
Witkiewicz, A. K., D. W. Cox, D. Rivadeneira, A. E. Ertel, P. Fortina, G. F. Schwartz and E. S. Knudsen (2013). "The retinoblastoma tumor suppressor pathway modulates the invasiveness of ErbB2-positive breast cancer." Oncogene.

Wonderlin, W. F., K. A. Woodfork and J. S. Strobl (1995). "Changes in membrane potential during the progression of MCF-7 human mammary tumor cells through the cell cycle." J Cell Physiol 165(1): 177-185.

Wong, J. V., P. Dong, J. R. Nevins, B. Mathey-Prevot and L. You (2011). "Network calisthenics: control of E2F dynamics in cell cycle entry." Cell Cycle 10(18): 30863094.

Wu, X., D. Zhong, B. Lin, W. Zhai, Z. Ding and J. Wu (2013). "p38 MAPK regulates the expression of ether a go-go potassium channel in human osteosarcoma cells." Radiol Oncol 47(1): 42-49.

Xue, Q., T. Sano, K. Kashiwabara, T. Oyama and T. Nakajima (2001). "Aberrant expression of pRb, p16, p14ARF, MDM2, p21 and p53 in squamous cell carcinomas of lung." Jpn J Cancer Res 92(3): 285-292.

Yamasaki, L., R. Bronson, B. O. Williams, N. J. Dyson, E. Harlow and T. Jacks (1998). "Loss of E2F-1 reduces tumorigenesis and extends the lifespan of Rb1(+/)mice." Nat Genet 18(4): 360-364. 
Yamasaki, L., T. Jacks, R. Bronson, E. Goillot, E. Harlow and N. J. Dyson (1996). "Tumor induction and tissue atrophy in mice lacking E2F-1." Cell 85(4): 537-548. Yamazaki, K., T. Yajima, T. Nagao, H. Shinkawa, F. Kondo, K. Hanami, A. Asoh, I. Sugano and Y. Ishida (2003). "Expression of transcription factor E2F-1 in pancreatic ductal carcinoma: an immunohistochemical study." Pathol Res Pract 199(1): 23-28.

Yasutis, K. M. and K. G. Kozminski (2013). "Cell cycle checkpoint regulators reach a zillion." Cell Cycle 12(10): 1501-1509.

Zhu, W., P. H. Giangrande and J. R. Nevins (2004). "E2Fs link the control of G1/S and G2/M transcription." EMBO J 23(23): 4615-4626.

Ziechner, U., R. Schonherr, A. K. Born, O. Gavrilova-Ruch, R. W. Glaser, M. Malesevic, G. Kullertz and S. H. Heinemann (2006). "Inhibition of human ether a gogo potassium channels by $\mathrm{Ca} 2+/$ calmodulin binding to the cytosolic $\mathrm{N}$ - and $\mathrm{C}$ termini." FEBS J 273(5): 1074-1086. 


\section{Diana Urrego-Blanco}

Phone: +49 (0) 551 3899-635

Hermann-Rein-

Straße 3

urrego@em.mpg.de

37075 Göttingen

\section{EDUCATION}

Sep 2009/ present Msc/PhD Neuroscience Program

International Max-Planck Research School (IMPRS), Göttingen, Germany

Sep 2003/ Feb 2009 Bachelor of Science, "Biology",

Universidad Nacional de Colombia, Bogotá, Colombia

\section{RESEARCH EXPERIENCE}

Oct 2010/ present Dissertation: "Dynamics of Kv10.1 expression through the cell cycle of cancer and non-cancer cells"

Department of Molecular Biology of Neuronal Signals, Oncophysiology Group, Max-Planck-Institute of Experimental Medicine, Göttingen, Germany. Advisor: Prof. Dr. Luis

Pardo.

Applied Methods: ChIP assays, luciferase reporter, Western blot, Flow cytometry, confocal microscopy.

Apr 2010/ Jun 2010 Laboratory Rotation: "Characterization of Smurf1 in granule neurons and its interaction with Cdh1-APC"

Department of Cellular and Molecular Neurobiology, Max Planck Institute for Experimental Medicine, Göttingen, Germany.

Supervisor: Dr. Judith Stegmüller,

Applied Methods: Western Blot, Co-immunoprecipitation, Immunostaining.

Mar 2010/ Apr 2010 Laboratory Rotation: "Mdulation of Olfactory Receptor Neurons by Orexin"

Dept. of Neurophysiology and Cellular Biophysics, Göttingen

University Medical School, Göttingen, Germany. 
Supervisor: Prof.Dr. Dr. Detlev Schild

Applied Methods: Calcium Imaging, Immunohistochemistry

Jan 2010/ Mar 2010 Laboratory Rotation: "Identification of NaV1.2 voltage dependent sodium channel in the human malignant astrocytoma cell line U87"

Department of Molecular Biology of Neuronal Signals,

Max-Planck-Institute of Experimental Medicine, Göttingen, Germany.

Supervisor: Prof. Dr. Walter Stühmer.

Applied Methods: Patch clamp, Immunostaining.

Feb 2008/ Feb 2009 Bachelor Thesis:"Structural changes induced on pyramidal cells of the primary motor cortex caused by complete and permanent injury of the contralateral facial nerve in rats"

Medical Faculty, Department of Physiology, Universidad Nacional de Colombia, Bogotá, Colombia.

Advisors: Dr. Alejandro Múnera and Dr. Julieta Troncoso

Applied Methods: Brain slice preparation, Two-photon microscopy, Stereotactic brain surgery.

April 2008 III Internatioanl course on Neurobiology:

Techniques for electrophysiological recording in neural preparations.

Universidad Nacional de Colombia, Bogotá, Colombia.

\section{TEACHING EXPERIENCE}

Nov 2013

Tutorials, Membrane physiology \& Ion Channels

International Max-Planck Research School (IMPRS), Göttingen,

Germany.

Mar 2012/ May 2012 Supervision of Laboratory Rotations, Molecular Medicine Program.

Göttingen University Medical School, Göttingen, Germany.

Jan 2012/ Feb 2012 Supervision of Laboratory Rotations, Neuroscience Program.

International Max-Planck Research School (IMPRS), Göttingen,

Germany 


\section{PUBLICATIONS}

Urrego D. and L. A. Pardo (2014). "Dynamics of Kv10.1 expression through the cell cycle of cancer and non-cancer cells." In preparation.

Sánchez, A., Urrego D. and L. A. Pardo (2014). "Cell cycle-dependent expression of Kv10.1 potassium channel regulates ciliogenesis." In preparation.

Urrego, D., A. P. Tomczak, F. Zahed, W. Stühmer and L. A. Pardo (2014). "Potassium channels in cell cycle and cell proliferation." Philosophical Transactions of the Royal Society B: Biological Sciences 369(1638).

Urrego, D., Munera, A., Troncoso, J. (2011). "Periferal facial nerve lesión induced long-term dendritic retraction in piramidal cortico-facial neurons." Biomedica. 31 (4): 560-9. 